\title{
SOIL MOISTURE TRANSPORT IN ARID SITE VADOSE ZONES
}

\author{
R. E. Isaacson \\ L. E. Brownell \\ J. C. Hanson \\ October 1974

\begin{abstract}
Physical and Life Science Technology Section Research Department Research and Engineering Division
\end{abstract}

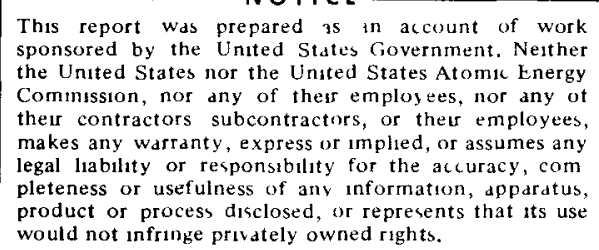

Operated for the Atomic Energy Commission by Atlantic Richfield Hanford Company under Contract AT(45-1)-2130 


\section{DISCLAIMER}

This report was prepared as an account of work sponsored by an agency of the United States Government. Neither the United States Government nor any agency Thereof, nor any of their employees, makes any warranty, express or implied, or assumes any legal liability or responsibility for the accuracy, completeness, or usefulness of any information, apparatus, product, or process disclosed, or represents that its use would not infringe privately owned rights. Reference herein to any specific commercial product, process, or service by trade name, trademark, manufacturer, or otherwise does not necessarily constitute or imply its endorsement, recommendation, or favoring by the United States Government or any agency thereof. The views and opinions of authors expressed herein do not necessarily state or reflect those of the United States Government or any agency thereof. 


\section{DISCLAIMER}

Portions of this document may be illegible in electronic image products. Images are produced from the best available original document. 


\section{TABLE OF CONTENTS}

Page

ABSTRACT • . . . . . . . . . . . . . . . . . . . .

LIST OF FIGURES

LIST OF TABLES . . . . . . . . . . . . . . . . . . . . . . . . v vi

INTRODUCTION AND BACKGROUND

BACKGROUND OF NAS-NRC RECOMMENDATIONS . . . . . . 1

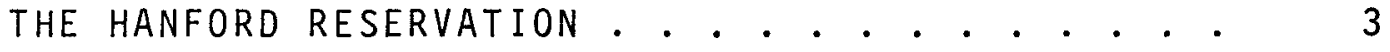

CLIMATOLOGICAL DATA F́R THE HANFORD RESERVATION . 6

STUDIES OF SOIL MOISTURE TRANSPORT

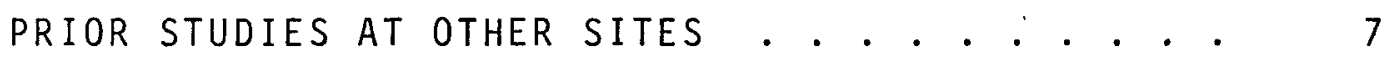

ORIGINAL STUDIES AT $32-49$ HANFORD COORDINATES . . 8

TRITIUM STUDIES

USE OF TRITIUM IN ENVIRONMENTAL WATER FOR

STUDY OF WATER TRANSPORT . . . . . . . . . . . . . . 11

TRITIUM PROFILES IN HANFORD SEDIMENTS . . . . . . . 14

SUPPLEMENTAL STUDIES . . . . . . . . . . . . . . 17

WATER POTENTIAL STUDIES

THE THERMOCOUPLE PSYCHROMETER STUDIES AT DEPTHS

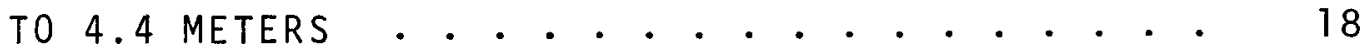

THERMOCOUPLE 'PSYCHROIIETER AND TEMPERATURE

MEASUREMENTS TO THE WATER TABLE AT $32-49$

COORDINATES

GEOTHERMAL GRADIENT AND SEASONAL TEMPERATURES CYCLES • 22

THE LYSIMETER EXPERIMENT • . . . . . . . . . . . . . . . 30

FUTURE WORK . . . . . . . . . . . . . . . . . . . 33

SUMMARY AND CONCLUSIONS . . . . . . . . . . . . . . . . . 35

REFERENCES . . . . . . . . . . . . . . . . . . . . 38 
TABLE OF CONTENTS (continued)

\section{APPENDIXES}

Page

A. COMMENTS FROM THE NATIONAL ACADEMY OF SCIENCENATIONAL RESEARCH COUNCIL . . . . . . . . . . . . 43

B. CLIMATOLOGICAL DATA FOR HANFORD (1971-1973) •. . 47

C. GEOTHERMAL GRADIENTS AT $32-49$ COORDINATES . . . . 51

¿. DIURNAL EFFECT . . . . . . . . . . . . . . . . 59

E. NUMERICAL APPROACH FOR THE CALCULATION OF

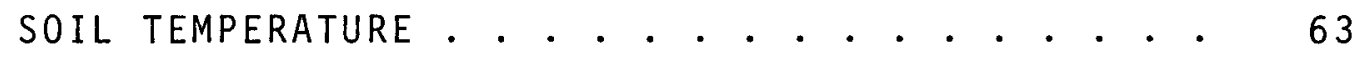

F. CONTAMINATION OF SOIL WATER DURING SAMPLING . . . 69 FIGURES • . . . . . . . . . . . . . . . . . . . . 71 DISTRIBUTION . . . . . . . . . . . . . . . . . . . . . . 93 


\section{ABSTRACT}

Soil moisture transport processes in the arid soils of the Hanford site are being evaluated. The depth of penetration of meteoric precipitation has been determined by profiling fallout tritium at two locations where the water table is about 90 meters below ground surface. In situ temperatures and water potentials were measured with temperature transducers and thermocouple psychrometers at one of these locations to obtain thermodynamic data for identifying the factors influencing soil-moisture transport. Neutron probes are being used to monitor soil moisture changes in two lysimeters, three meters in diameter by 20 meters deep. The lysimeters are also equipped to measure pressure, temperature, and water potential as a function of depth and time. Nonisothermal soil moisture transport processes are being studied. A thermal pump that moves water towards the surface exists as a result of annual sinusoidal oscillation of temperature in the upper nine meters of soil. A partially desiccated zone exists at a depth between 9 to 16 meters. Future work will be concerned with further study of these systems and the coupling of theoretical and experimental work and determining the amount of rainfall required to cause migration of soilmoisture to the water table. 


\section{LIST OF FIGURES}

FIGURE 1 Total Annual Precipitation (1913-1973) for the 200 Area Plgteau of the Hanford Reservation (after Jenne [6])

FIGURE 2 Annual Precipitation within the Columbia River Drainage Basin

FIGURE 3 Neutron Log of Wel1 2A (32-49A)

FIGURE 4 Water Potential versus Depth for Well $2 \mathrm{~A}(32-49 \mathrm{~A})$

FIGURE 5 Mean Monthly Tritium Concentration, Ottawa, Canada, and Central New Mexico

FIGURE 6 Schematic of Precipitation-Plume Interaction on Hanford Site

FIGURE 71969 Tritium Distribution in Soil Moisture

FIGURE 8 Groundwater Elevations and Flow Paths on Hanford Reservation (courtesy of Battelle)

FIGURE 9 Transport Mechanisms Basic to Moisture Redistribution in Semi-arid Vadose Zones

FIGURE 10 Weight Percent Soil Moisture and Average Water Potential Profiles at Well 32-49C as of May 5, 1970

FIGURE 11 Concentric Casing Method Used at Wel1 32-49D

FIGURE 12 Soil Moisture Profile at Well 32-49D

FIGURE 13 Water Potential as a Function of Moisture Content at well 32-490

FIGURE 14 Average In Situ Water Potential Profile at Well $32-490$

FIGURE 15 Hydraulic Conductivity and Thermal Diffusivity as a Function of Water Potential From Soil at 32-49D Well

FIGURE 16 Soil Temperature Profile at Well 32-49D on october 13, 1970 


\section{LIST OF FIGURES (continued)}

FIGURE 17 Average Measured Monthly Soil Temperature for Three Selected Months as a Function of Depth at We $1132-490$

FIGURE 18 Average Measured Monthly Soil Temperature $\left({ }^{\circ} \mathrm{C}\right)$ versus Time for Selected Depths at Well 32-49D

FIGURE 19 Magnitude of Thermal Driving Forces as a Function of Depth and Time

FIGURE 20 Schematics of Lysimeter Including Site Elevation and Plan at the 32-49D Hanford Coordinates

FIGURE 21 Closed Lysimeter Moisture Percent by Volume as of September 6, 1973

FIGURE 22 Closed Lysimeter Moisture Profile, Percent for November 1972 and November 1973

FIGURE C-1 Geothermal Gradient at 32-49 Coordinates at Depths Below 6 Meters

FIGURE C-2 Annual Cyclic Thermal Driving Force at 32-49 Coordinates Between 6.1 to 4.0 Meter Depths

FIGURE C-3 Annual Cyclic Thermal Driving Force at 32-49 Coordinates Between 4.0 to 2.7 Meters

FIGURE C-4 Annual Cyclic Thermal Driving Force at 32-49 Coordinates Between 2.7 to 1.8 Meters

FIGURE C-5 Annual Cyclic Thermal Driving Force at 32-49 Coordinates Between 1.8 to 0.9 Meters

FIGURE C-6 Annual Cyclic Thermal Driving Force at 32-49 Coordinates Between 0.9 to 0.3 Meters

FIGURE C-7 Annual Cyclic Thermal Driving Force at 32-49 Coordinates Between 0.3 to 0.076 Meters

FIGURE D-1 Average Hourly Temperatures (1955-1970) for the First Six Months of the Year

FIGURE D-2 Average Hourly Temperatures (1955-1970) for the Last Six Months of the Year

FIGURE F-l Tritium Analyses of Soil Moisture in Soil Samples at Well 12-48 


\section{LIST OF TABLES}

TABLE I Particle Size Analysis and pH of Soil Paste for We $1132-49 A$

Annual Average Tritium Content (TU) in Metegric
Precipitation in North America and Europe 32 )

TABLE III Tritium Assay Values for Wells 19-47B, 32-49B and $32-490(6)$

TABLE IV Soil Separates for Profile at Instrument Installation in Well 32-49D

TABLE $V$ Least Square Calibration for Temperature Profile

TABLE VI Values Shown in Figure 19 and Corresponding Driving Forces

TABLE B-I Weather Data During 1971-73 Study

TABLE B-II Temperature and Mean Sky Cover During 1971-1973 TABLE B-III Solar Radiatjon and Wind Activity During the 1971-
1973 Study 


\section{INTRODUCTION AND BACKGROUND}

Waste management practices at the United States Atomic Energy Commission Hanford site near Richland, Washington have included burial of radioactive wastes in backfilled trenches and discharge of low-level aqueous wastes into sub-surface facilities where radionuclides, including actinides, have been sorbed on the sediments. These waste disposal practices have successfully isolated the radionuclides in the relatively dry sediments, high above the regional water table. Several papers have been presented on these disposal practices. (e.g. 1,2)

The amount and rate of precipitation necessary to establish percolation to the water table in various types and thicknesses of soil and rock continues to be of concern to reviewers. The Committee on Geologic Aspects of Radioactive Waste Disposal of the National Academy of Sciences - National Research Council stated in their report in $1966^{(3)}$ that, "The Committee is dubious about the concept that in arid and semiarid lands meteoric water does not percolate downward as far as the water table but instead is lost entirely by evaporation and plant transpiration." The Committee recommended that, "The movement of water, both upward and downward, under varying conditions of wetting in the zone of aeration at National Reactor Test Site, Idaho (NRTS) and Hanford, Washington should be thoroughly studied, particularly with reference to questions about percolation of rain water and snow melt to the water table."

This report discusses the findings of ongoing research which is concerned with an analysis of the physical processes that affect the rate and direction of moisture movement in the vadose zone of the dry soils at Hanford. 
BACKGROUND OF NAC-NRS RECOMMENDATIONS

A committee of geologists and geophysicists was established in 1955 by the National Academy of Sciences National Research Council at the request of the Atomic Energy Commission to consider the possibilities of disposing of highlevel radionuclide wastes in quantity within the continental limits of the United States. The Committee first assembled in April 1955 and began as a steering committee whose principal function was to assist the AEC'S Division of Reactor Development and its agents in a search for safe methods of ground disposal of hazardous wastes. From late 1955 until mid-1960, the Committee was known as the Committee on Waste Disposa 1 ; in January 1961, it was renamed the Committee on Geologic Aspects of Radioactive Waste Disposal.

The work of this Committee was supported by the Division of Reactor Development and Technology of the United States Atomic Energy Commission, for whom the Committee serves as advisor. The Committee's responsibility to that Division is to observe and study, critically, the research and development activities of the Division with respect to disposal of radionuclide wastes in the ground, and to provide counsel regarding the safety of the Division's current and proposed operations insofar as they are affected by geologic consideration. This committee early established for itself a set of guidelines which it continues to observe. In September 1955, as a result of action by the Committee, a conference was held at Princeton with 65 participants including representatives of $A E C$, members of the Department of Sanitary Engineers of John Hopkins University, representatives of the U. S. Geological Survey, industry, and many individual scientists competent in relevant fields. (4) Informed opinions were rendered at the conference with some of their conclusions stated in Appendix $A$. The most promising concept was considered to be that of storage of 
radioactive wastes in salt deposits. This recommendation is under investigation as is that of conversion of radioactive wastes to more durable forms such as silicates and aluminosilicates. Silicate forms stored in arid areas has received only limited consideration. All methods considered feasible for long-term storage of radioactive wastes are based on the concept of preventing radioactive material from dispersal in natural water supplies, i.e., groundwater, water courses, and the oceans. This is because if such dispersal should occur at any point, the process is in practice irreversible and it is, for practical purposes, impossible to regain control of the radioactive substances dissolved or suspended in the water. Because of the basic criterion of maintaining a separation between radioactive wastes and natural water supplies, Erichsen (5) has proposed that radioactive materials be stored in arid areas.

The NAS-NRC Steering Committee, however, has had some reservations regarding such use of arid areas until soilmoisture transport in arid site vadose zones is better understood.

The studies on soil moisture transport in arid-site vadose zones thus, are pursuant to the recommendations of the National Academy of Science - National Research Council Committee on Geologic Aspects of Radioactive Waste Disposal. Before discussion of these studies, a brief review of some of the unusual features of the Hanford site is pertinent.

\section{THE HANFORD RESERVATION}

The Hanford reservation, operated by contractors of Atomic Energy Commission - Richland Operations Office, is located in the Pasco Basin of south central Washington.

The chemical processing and waste management (200) areas of the reservation are located on a plateau which slopes towara 
the Columbia River. The river passes about 16 kilometers north of the 200 area and the plateau extends to the foothills of Rattlesnake Mountain about 16 kilometers south. Elevation of the weather station in the 200 area is 223 meters, which is roughly 90 meters above the Columbia River.

Several unusual geological features of the Hanford site are of significance in management of radionuclide wastes on the Hanford reservation. One is the low soil-moisture content on the plateaus of the arid Hanford site that essentially limits water movement in the soil to vapor transport from the water table to the surface. Others are the depth to the water table and the soil stratification that aid in immobilization of waste.

The area of Eastern Washington has become progressively more arid for the past 10,000,000 years, corresponding to the rise of the Cascade Mountains. As these mountains have risen, they have cooled the prevailing winds from the Pacific and have stripped them of their water. This is also true of the coastal range which accounts for the present annual rainfall of over 7.6 meters on the $01 y m p i c$ Peninsula. In the present climate, after the westerly winds are twice stripped of water, there is little moisture left for Eastern Washington. During the last ice age, the Hanford area was not as arid as at present. There is evidence that there have been at least 7 floods of the Pasco Basin, of which 4 were major. All were related to glacial activity which produced glacier lakes in the area near Missoula, Montana. As these lakes broke up and released great volumes of water and ice, they produced the "scablands" in Eastern Washington. About 20,000 years ago, such a flood occurred and left water marks 380 meters above sea level in the Pasco Basin. Another occurred about 11,000 years ago and was 270 meters above sea level. About 1,000 years later, a third occurred, but was only about 180 meters above sea level. 
The Pasco Basin also has had periods when it was much more arid than it is at present. Studies of the Ginkgo Park area near Vantage (about 115 kilometers upriver from Richland) have produced ventifacts attesting to wind erosion as the result of very arid climate. Estimates of the rate of flow in the Columbia River about 6,000 years ago are down to 300 to $1,000 \mathrm{~m} / \mathrm{sec}$ which is about $1 / 10$ the present flow rate. The conclusion is that the area has had a semi-arid climate for the last 10,000 to 20,000 years (since the last ice age). Future precipitation is expected to remain low for thousands of years because of the permanence of the Cascade Mountains.

Average annual precipitation at Hanford is about 16 centimeters per year as shown in Figure 1 after Jenne. $(6)$ The total annual rainfall ranges from about eight centimeters to about 28 centimeters. Residual moisture in the Hanford sediments below a depth of 10 meters ranges from about 1.5 to about $4 \%$ with a mean value of about $2 \%$, by weight. Water content retained by capillarity ranges from 4 to 5 percent, by weight. Based on these data a full year of precipitation of 16 centimeters would satisfy the soil moisture deficiency to a depth of less than 8.0 meters if no loss to the atmosphere or redistribution other than capillary transport occurred. Soil drainage predictions would give a somewhat greater depth of penetration. Because of the complexities of soil moisture movement in the vadose zone of arid sites, in-depth soil moisture transport studies were initiated at Hanford in 1969. In looking for possible recent trends, one may note that the 10 west annual precipitation in 50 years of record of 8.4 centimeters occured in 1965. The use of water for irrigation of crops in the surrounding agricultural areas does not indicate any trend toward an increase in annual rainfall, contrary to some popular opinions.

Figure 2 shows a map of the Columbia River Drainage Basin 
which includes most of the land area in the states of Washington, Oregon, and Idaho and reaches into Montana and British Columbia, Canada. (7) The map indicates the different zones for normal annual precipitation. The Hanford site lies in the approximate center of the most arid zone (less than 25 centimeters precipitation) in the Northwest.

\section{CLIMATOLOGICAL DATA FOR THE HANFORD RESERVATION}

Climatological data based on records compiled by the Hanford Meteorology Station from 1945-1970 and supplemented with precipitation and temperature data of the United States Weather Bureau cooperative observers at a nearby site from 1912 to 1944 are summarized by Hsieh, Reisenauer and Brownell in this section.

The Hanford Reservation is in the rain shadow of the Cascade Mountains. The average precipitation totals only 16 centimeters annually. The three months of November through January contribute 42 percent of this total, while the three months of July through September contribute only 10 percent. There are only two occurrences per year of 24 -hour amounts 1.27 centimeters or more. About 45 percent of all precipitation during the months of December through February is in the form of snow. There have been 81 consecutive days without measurable rain (June 22 to September 10, 1967, 139 days with only 0.46 centimeters (June 22 to November 7, 1967), and 172 days with only 0.81 centimeters (February 24 to August 13, 1968).

By serving as a source of cold air drainage, the Cascade Mountains also have a considerable effect on the wind regime at Hanford Reservation. This drainage (gravity) wind, plus topographic channeling, causes a considerable diurnal range of wind speed during the summer. In July, hourly average speeds range from a low of 8.4 kilometers per hour from 9:00 am to 10:00 am to a high of $21 \mathrm{kilometers} \mathrm{per} \mathrm{hour} \mathrm{from} \mathrm{9:00} \mathrm{pm}$ to $10: 00 \mathrm{pm}$. In contrast, the corresponding speeds for January are 8.8 and 10.1 kilometers per hour. 
Temperatures at the Hanford Project are colder in winter and warmer in summer than would be the case without the Cascade Mountains. However, other mountain ranges shield the area from many of the artic air mass surges. Hanford experiences may warm, cloudless days and, as a result, the solar radiation is consistently high.

Although winter temperature minima have varied from $-33^{\circ} \mathrm{C}$ to $-5.6^{\circ} \mathrm{C}$, summer maxima have varied on 1 y $38^{\circ} \mathrm{C}$ to $46^{\circ} \mathrm{C}$. There is, however, considerable variation in the frequency of such maxima.

The weather data during the experimental period for the water potential studies are reported in Tables B-I, B-II, and $B-I I I$ in Appendix $B$. Table $B-1$ shows the monthly precipitation and relative humidity data which exhibit no great departure from the average. Table B-II shows the temperature and mean sky cover for the test period which again is near the long-term average. Table B-III shows the solar radiation and wind activity over the test period. Departure from the average solar radiation is on the high side with winds near normal except for peak gusts.

\section{STUDIES OF SOIL MOISTURE TRANSPORT}

\section{PRIOR STUDIES AT OTHER SITES}

Several attempts have been made to measure drainage and water retention properites of the Hanford sediments using tensionmeters or suction plates. $(8,9)$ Whereas, these techniques are suitable for establishing irrigation and drainage practices for agricultural purposes, the techniques did not provide sufficient sensitivity for measuring moisture transport in sediments which contained about 1.5 to 3.0 percent water, by weight. $(10-12)$ Initial studies raised perplexing questions about the physical processes that effect moisture 
movement in these arid sediments. For example, analyses of measurements using a suction plate apparatus in the laboratory predicted that perhaps as much as 20 to 25 millimeters of water percolated to the water table. Such quantities appeared to be unrealistic and a more extensive understanding of moisture movement appeared warranted. Minor mechanisms for soil moisture transport such such as vapor phase transport influenced by gravity, capillarity, thermal gradients, temperatureinduced buoyancy, evapotranspiration and barometric compression and expansion became the primary mechanisms in arid and semiarid regions. Transport due to electrical gradients should be considered. $(13,14)$ Freezing at the ground surface is a special case of transport due to thermal gradients. (15) Several investigators, including Zimmerman and his coworkers at the University of Heidelberg, $(16,17)$ Smith and his coworkers in England, (18) Schmalz and Polzer at Idaho Falls, (19) and Richards of the Commonwealth Scientific and Industrial Research organization, Melbourne, Australia $(20,21)$ have studied the movement of moisture in the zone of aeration. The geologic and climatic settings of these studies differ significantly from those on Hanford reservation, thus limiting their applicability in characterizing moisture movement in the Hanford soil.

\section{ORIGINAL STUDIES AT 32-49 HANFORD COORDINATES}

Hanford coordinates 32-49 give the location of four wells $A, B, C$, and D - southeast of the 200 East Area and within about 15 meters of each other, that are being used in the study of soil-moisture relations.

The wells are located in an area where the predominate vegetative cover is sagebrush (Artemisia tridentata) and cheatgrass (Bromus tectorum L.). The soil of this location is a relatively uniform sand to loamy sand throughout the soil profile with the water table approximately $96 \mathrm{~m}$ below the surface. 
Well 32-49A was Number 2 in a series of 12 wells drilled in the sandy plateau southeast of the 200 East Area in June 1969. This well was not drilled to the water table, but only to a depth of 76 meters where coarse gravel and cobble stones were encountered and drilling was terminated. The neutron well $10 \mathrm{~g}$, shown in Figure 3 , indicates this well to be one with a low and quite uniform moisture content of about 5 to 9 volume percent water.

Figure 4 is a plot of water potential in negative bars based on laboratory measurements using samples of soil removed during dry-drilling of well 32-49A. A trend with percent silt (obtained from Table I) is indicated by the arcing of values as shown in Figure 4. This is quite apparent at depths from 29 to 41 meters. Arcing shown in Figure 4 at this depth indicates that a single stratified zone may exist between 29 to 37 meters depths. As shown in Figure 4 , the greatest negative potential of -29 bars occurs in this zone at 29 meter depth in soil with a silt plus clay content of 12.1 percent. The potential rises (approaches zero) continuously and the silt content drops continuously as the depth increases to 37 meters. Here the negative water potential has increased from -29 to -12 bars and the content of silt and clay has dropped to 3.4 percent. Sharp layering apparently occurs in the next 4.6 meters of depth. At 38.1 meter depth, the silt content has increased to 6.6 percent and the water potential has decreased to -31 bars. At 39.6 meter depth, only 1.5 meters below, the silt content has decreased to 1.9 percent and the water potential has increased to -6 bars. One and one-half meters further down at 41.4 meters depth, the silt and clay content were 11.3 percent and the water potential was -35 bars. Thus, the influence of particle size (expressed by percent silt plus clay) on water potential as determined in the laboratory, is significant. However, this influence was thought to disappear to a large extent with in situ measurements when 


\section{TABLE I}

PARTICLE SIZE ANALYSIS AND PH OF SOIL PASTE

AND $0.01 \mathrm{~m} \mathrm{CaCl}_{2}$ FOR WELL NUMBER $2 \mathrm{~A}(32-49 \mathrm{~A})$

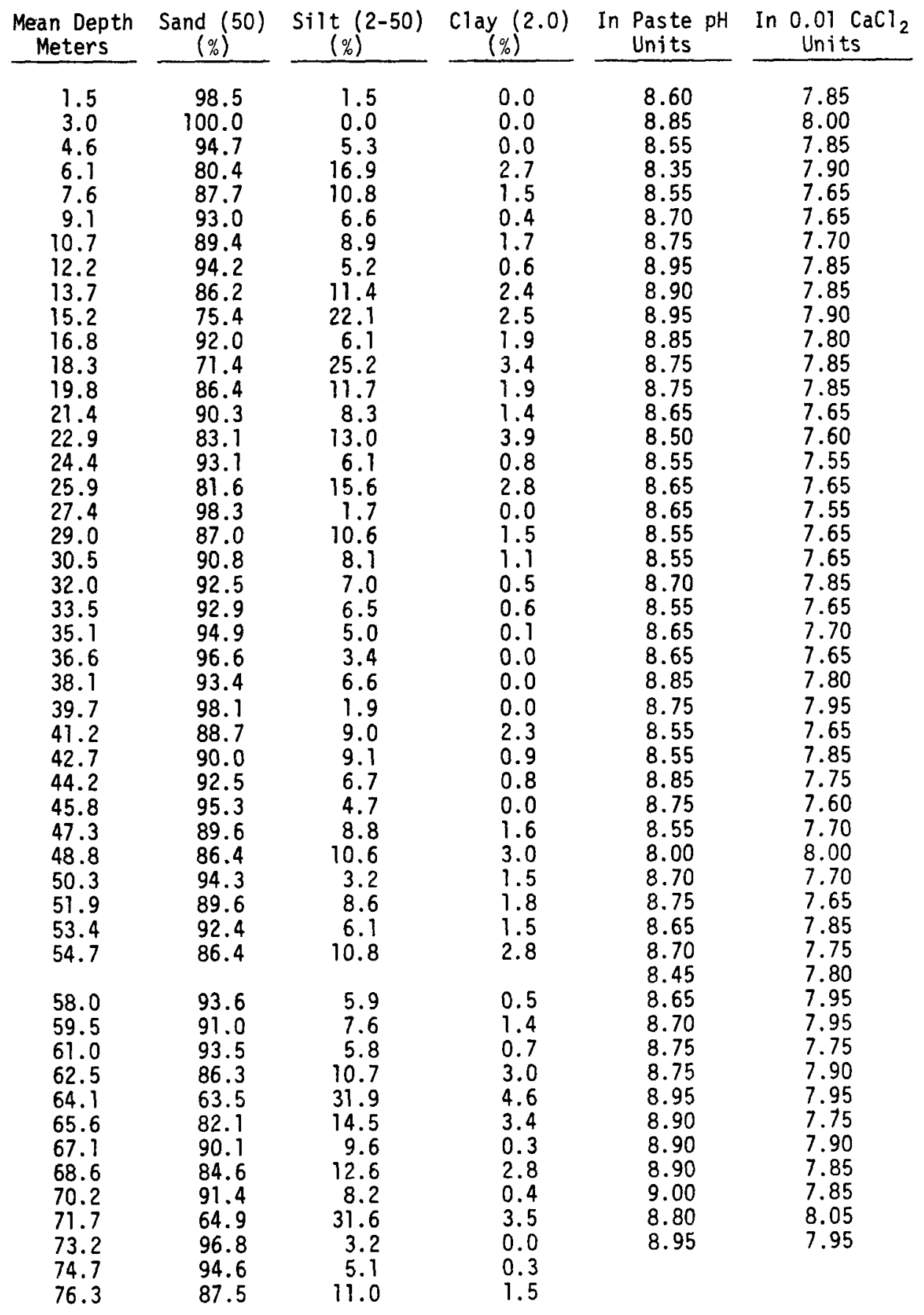


the soil is not stratified.

\section{TRITIUM STUDIES}

USE OF TRITIUM IN ENVIRONMENTAL WATER FOR STUDY OF WATER TRANSPORT

The release of artificial tritium to the atmosphere by the testing of nuclear fusion weapons provided an opportunity to explore a number of hydrological and meterological phenomena using the hydrogen isotope technique. Natural tritium is produced in the atmosphere by cosmic photons and solar flare accelerated particle interactions in the upper atmosphere. one mechanism is the result of secondary neutrons by a reaction described by Libby in 1946.23) In 1951, Faltings and Harteck $(24)$ and Grosse, et al ., (25) independently reported on the production of natural tritium.

$$
{ }_{7}^{14} N+{ }_{0}^{1} n \rightarrow{ }^{12} C+{ }_{1}^{3} T+\text { energy }
$$

Natural tritium is produced at an estimated rate of about 30 atoms per minute per square centimeter of the earth's surface according to computations by suess (26) and others (27-28) This is equivalent to an inventory of about $3.5 \mathrm{~kg}$ of tritium (29) or a concentration of about 10 TU* in atmospheric water prior to 1953. Since then, experiments with thermonuclear devices rapidly increased the tritium inventory by a factor of 50 or more, especially in 1962 and 1963, to about 300 disintegrations per minute per square centimeter of the earth's surface. (26) This corresponds to the addition of nearly 200 kilograms of tritium to the earth's inventory. The moratorium on atmospheric testing of nuclear weapons by USA and Russia has reduced further additions by these countries since 1964. Tritium with a halflife of 12.33 years, decays to stable helium-3 with emission of an $0.018 \mathrm{Mev}$ beta particle according to the following equation. 


$$
{ }_{1}^{3} \mathrm{~T} \rightarrow 12.33 \text { y }{ }_{2}^{3} \mathrm{He}+{ }_{-1}^{0} \mathrm{~B} 0.018 \mathrm{Mev}
$$

Artificial tritium may be produced by either or both of the following thermonuclear reactions.

$$
\underbrace{\mathrm{Al}^{3} \mathrm{He}+0^{n}+3.3 \mathrm{Mev}}_{1^{3}+1^{1} \mathrm{p}+4.0 \mathrm{Mev}}
$$

These equations indicate the large amount of tritium resulting from fusion reactions and corresponds to $10^{23}$ to $10^{24}$ atoms/kt of fusion depending upon the efficiency and type of thermonuclear fuel. (30)

Since the peak in tritium concentration from atmospheric thermonuclear tests occurred in the early 1960s, the tritium concentration has decreased by decay. Also, precipitation has slowly transferred much of the tritium from the upper atmosphere to the oceans.

Although tritium is released in elemental form as an isotope of hydrogen, it is readily oxidized and is essentially present in the atmosphere in the form of water as HTO and $\mathrm{T}_{2} 0$. As a result, all water present on the surface of the earth is tagged with measurable amounts of tritium. This includes water vapor in the atmosphere, precipitation as rain or snow, rivers, lakes, oceans, and some underground water. The levels of natural tritium are very low, and a unit of 
measurement less than the curie or micro-curie is needed. Such a unit is the Tritium Unit (TU) and is defined as the ratio of the number of tritium atoms per $10^{18}$ hydrogen atoms. The natural tritium concentration of rainwater is about 5 TU according to one reference (31) and about $10 \mathrm{TU}$ according to another. (32) The addition of artificial tritium to the upper atmosphere has resulted in an increase in concentration to several thousand TU in some rains in the early 1960s. In 1963, TU values of some rains rose to over $20,000 \mathrm{TU}$. In general, the precipitation from higher altitudes contains a higher concentration of tritium than that from lower altitudes. Table II lists Tritium Unit Values for Precipitation for North America (Ottawa, Canada) and for Europe (average) for different years from 1951 to 1968. (33)

TABLE II

\begin{tabular}{|c|c|c|c|c|c|}
\hline \multirow{2}{*}{$\begin{array}{l}\text { METEORIC } \\
\text { YEAR }\end{array}$} & \multicolumn{4}{|c|}{$\begin{array}{l}\text { ANNUAL AVERAGE TRITIUM CONTENT (TU) IN } \\
\text { PRECIPITATION IN NORTH AMERICAN (OTTAWA, } \\
\text { AND EUROPE (AVERAGE) }\end{array}$} & \multirow{2}{*}{$\begin{array}{l}\text { (ANADA) } \\
\text { AVERAGE }\end{array}$} \\
\hline & $\begin{array}{l}\text { CANADA } \\
\text { OTTAWA } \\
\end{array}$ & $\begin{array}{l}\text { EUROPE } \\
\text { AVERAGE }\end{array}$ & YEAR & $\begin{array}{l}\text { CANADA } \\
\text { OTTAWA }\end{array}$ & \\
\hline 1952 & 20 & 20 & 1961 & 219 & 110 \\
\hline 1953 & 30 & 25 & 1962 & 988 & 700 \\
\hline 1954 & 302 & 300 & 1963 & 3032 & 2500 \\
\hline 1955 & 45 & 35 & 1964 & 1565 & 1300 \\
\hline 1956 & 146 & 100 & 1965 & 865 & 580 \\
\hline 1957 & 126 & 125 & 1966 & 590 & 240 \\
\hline 1958 & 515 & 300 & 1967 & 315 & 160 \\
\hline 1959 & 540 & 450 & 1968 & 214 & 150 \\
\hline
\end{tabular}

Figure 5 shows two sets of data, one for 0ttawa, Canada (IAEA, 1969, 1970, 1971), and the other for central New Mexico, 
plotted together with indications of the history of nuclear testing in the atmosphere. (32) Nuclear testing between September 1961 and December 1963 produced large tritium yields as shown in Figure 5 by the high tritium levels following 1962. Although Ottawa, Canada and Albuquerque, New Mexico differ in latitude and longitude, the data in Figure 5 shows considerable overlap. The tritium concentration in precipitation upwind from the Hanford reservation would be expected to have a similar profile to that in Figure 5.

Tritium is a fission product and appears in the aqueous streams in the separation of fission products from irradiated fuel. Vapor from water during processing is vented to the stack and may be removed downstream by precipitation as indicated in Figure 6 and discussed by Hales. (34) As a result, tritium values in precipitation on the Hanford site vary from location to location and may be expected to be somewhat greater than predicted by Figure 5 .

\section{TRITIUM PROFILES IN HANFORD SEDIMENTS}

On the Hanford reservation deep underground water from slow-moving aquifers and water collected from deep underground soil, believed free from water percolation, has been found to have tritium concentrations of less than 10 tritium units (TU). As a result, neither liquid scintillation nor gas counting techniques alone are satisfactory for study of the tritium profile. Electrolytic enrichment plus gas counting can provide tritium analyses as low as three to five TU (the limit of detectability with an accuracy of $\pm 0.5 \mathrm{TU}^{(35)}$ and was the method of analysis used in these studies. The analyses were performed by Isotopes, Inc., a division of Teledyne in Westwood, New Jersey.

Special sampling techniques were necessary to prevent contamination of the soil samples in which the tritium con- 
centration was less than 10 TU. In preliminary sampling tests, soil samples were collected and handled in plastic bags.

Contamination during sampling was indicated by tritium concentrations of $100 \mathrm{TU} \pm 30 \mathrm{TU}$ in soil moisture extracted from virgin samples of soil. This problem was solved by using five-liter glass bottles with ground glass joints as soil sample containers. To remove moisture adsorbed on the inside glass surface of the container, the bottles were rinsed with dry acetone and dried by flushing with dry-pumped argon or nitrogen gas. Containers were prepared in this manner at the well site at the time of sampling. Added precautions involved rapid transfer of the soil sample to the container after its removal from the well bore, use of surgical rubber gloves to prevent contamination of soil by moisture from the hands, and storage of the samples in the shade until they were transferred to the laboratory.

The initial measurements of soil samples from well 32-49A indicated that the soil is a slightly-stratified, silty sand (moisture content about 2-3 weight percent) to a depth of about 76 meters. The tritium assay results are listed in Table III for soil samples collected during the drilling of wells 32-49B, 32-49D, and 19-47B (about four kilometers south of 32-49 coordinates). The data for these wells may be considered to be representative of the vertical tritium distribution in virgin vadose zones of the Hanford soils. A plot of the data for the top 70 meters of each well is shown in Figure. 7.

The surface value of $1490 \pm 50$ TU for well 19-47B is considered to have been influenced by the tritium concentration in the last atmospheric precipitation prior to sampling. As shown in Figure 7 , the tritium concentration decreases logarithmically from the surface to a depth of 4.6 meters where it has dropped to a value of $17.1 \pm 0.9 \mathrm{TU}$. The tritium 
TABLE I I I

TRITIUM ASSAY VALUES FOR WELLS 19-47B, 32-49B, and 32-49D

\begin{tabular}{|c|c|c|c|c|c|}
\hline \multicolumn{2}{|c|}{$\begin{array}{c}\text { Wel1 } 19-47 \text { B } \\
\text { Drilled } \\
\text { October } 1969\end{array}$} & \multicolumn{2}{|c|}{$\begin{array}{c}\text { Well } 32-49 \mathrm{~B}^{1} \\
\text { Drilled } \\
\text { December } 1969\end{array}$} & \multicolumn{2}{|c|}{$\begin{array}{c}\text { Wel1 } 32-49 D^{2} \\
\text { Drilled } \\
\text { June } 1970\end{array}$} \\
\hline $\begin{array}{l}\text { Depth, } \\
\text { Meters }\end{array}$ & $\begin{array}{l}\text { Tritium } \\
\text { Units } \\
\end{array}$ & $\begin{array}{l}\text { Depth, } \\
\text { Meters }\end{array}$ & $\begin{array}{l}\text { Tritium } \\
\text { Units }\end{array}$ & $\begin{array}{l}\text { Depth, } \\
\text { Meters }\end{array}$ & $\begin{array}{c}\text { Tritium } \\
\text { Units } \\
\end{array}$ \\
\hline 0 & $1490 \pm 50$ & 0 & $236 \pm 12$ & 0 & $481 \pm 15$ \\
\hline 2.3 & $222 \pm 10$ & & & 3.0 & $142 \pm 7$ \\
\hline 3.4 & $112 \pm 5$ & & & 4.6 & $13,000 \pm 1000^{3}$ \\
\hline 4.6 & $17.1 \pm 0.9$ & & & 5.5 & $24.9 \pm 1.0$ \\
\hline 6 & $4.9 \pm 0.3$ & 6.4 & $5.3 \pm 0.4$ & 6 & $17.9 \pm 0.9$ \\
\hline 9 & $5.5 \pm 0.3$ & 9.5 & $4.0 \pm 0.3$ & 8.1 & $8.2 \pm 0.5$ \\
\hline 12 & $3.7 \pm 0.3$ & 12.5 & $5.5 \pm 0.4$ & 12 & $14.9 \pm 0.9$ \\
\hline 18 & $4.4 \pm 0.3$ & & & 15 & $8.9 \pm 0.6$ \\
\hline 27 & $4.5 \pm 0.3$ & 29 & $6.9 \pm 0.4$ & 26 & $6.6 \pm 0.4$ \\
\hline 41 & $6.3 \pm 0.4$ & 72 & $7.4 \pm 0.4$ & 34 & $7.9 \pm 0.5$ \\
\hline 46 & $9.5 \pm 0.5$ & 87 & $8.6 \pm 0.5$ & 43 & $5.5 \pm 0.4$ \\
\hline 53 & $9110 \pm 300^{3}$ & 91 & $26 \pm 9^{4}$ & 61 & $11.4 \pm 0.6$ \\
\hline 53 & $20 \pm 6$ & & & 70 & $8.4 \pm 0.5$ \\
\hline 59 & $9.4 \pm 0.5$ & 94 & $\sim 20^{4}$ & $79^{5}$ & $12.9 \pm 0.7$ \\
\hline 64 & $4.5 \pm 0.3^{5}$ & 94 & $\sim 20^{4}$ & $94^{5}$ & $28.7 \pm 1.4^{5}$ \\
\hline
\end{tabular}

'Sample flasks flushed with argon.

${ }^{2}$ Sample flasks flushed with nitrogen.

${ }^{3}$ Excessively high values probably result from contamination from the cable of the drill rig or from a clump of contaminated soil from the inside of the drive barrel. A check was made with a second sample (stored in

plastic bag) from 53 meters depth from well 19-47 B. A gas count of the second sample gave a tritium assay of $20 \pm 6 \mathrm{~T} . \mathrm{U}$.

${ }^{4} \mathrm{Gas}$ count without electrolytic enrichment of sample.

${ }^{5}$ Liquid water from water table. 
concentration for wel1 19-47B from a six-meter depth to the water table is shown in Table II to be less than 10 TU for all measurements and 5.5 TU or less for two-thirds of the measurements in this zone. These low values are consistent with water isolated from atmospheric contamination for the past 25 or more years. Some prior contamination occurs in recovery of water from the soil samples, possibly in the range of 2 to 8 TU, which may account for the observed values of 3 to 10 TU. (See Appendix G) The tritium assay values for samples from well 32-49B generally parallel those from well 19-47B. Exceptions are a lower tritium assay value at the surface $(236 \pm 12$ TU). The value of $26 \pm 9$ TU at the 91 -meter depth indicates that the tritium concentration is greater in the groundwater and directly above the water table for well 32-49B than for well 19-47B in which the tritium assay for the groundwater only $4.5 \pm 0.3 \mathrm{TU}$. This difference indicates probably contamination of the groundwater at the 32-49 coordinates from waste facilities up-gradient from the well site as indicated by the groundwater flow paths shown in Figure 8.

The sample from below the top of the water table ( 94 meters) for well 32-49D was a liquid water sample. The tritium assay of $28.7 \pm 1.4$ TU is considered to be essentially free from error. This value supports the earlier values of 21 and 26 \pm 9 TU determined by gas counting without enrichment for well 32-49B. Although the tritium measurements successfully define the limits of migration of recent precipitation, the physical processes that affect moisture movement could not be identified and are still under investigation.

\section{SUPPLEMENTAL STUDIES}

The tritium profile measurements have been supplemented by a number of other studies. Factors that influence soil moisture movement are shown in Figure 9. Water is added to 
the surface by meteoric precipitation and is removed by gravity flow, evapotranspiration, evaporation, advection and by the influence of annual and diurnal cycling plus climatic oscillations in temperature and barometic pressure at the ground surface. These oscillations create thermal and pressure pumps that remove moisture by small flow mechanisms. A number of questions must be resolved to determine which mechanisms shown in Figure 9 are additive, which are opposing, which experience reversals, what are the relative magnitudes, and whether the net redistribution of moisture is upward or downward.

\section{WATER POTENTIAL STUDIES}

\section{THE THERMOCOUPLE PSYCHROMETER STUDIES AT DEPTHS TO 4.4 METERS}

The first major attempt to establish whether or not meteoric water percolates to deep underground water on the 200 Area plateau of the Hanford reservation involved the use of thermocouple psychrometers. Hsieh of Battelle Pacific Northwest Laboratories (BNW) proposed that because water migrates from a high water potential to a lower potential, the potential gradient, i.e., the slope of the water potential curve versus depth could be used to establish the direction of water transport as well as the magnitude of the driving force (isothermal condition). This concept is based on thermodynamics.

Enfield and Hsieh (36) demonstrated the application of thermocouple psychrometers to the determination of soil water transport with instruments located in situ to a depth of 4.4 meters in a test site at Hanford 32-49C coordinates. Determinations reported for May 5, 1970, see Figure 10, showed positive potential gradients vertically upwards at depths of 3.39 meters or less. Gradients were negative at depths of 3.81 , and 4.40 meters. For the site at well $32-49 \mathrm{C}$ and as of 
May 5, 1970, Enfield and Hsieh concluded "that above about $300 \mathrm{~cm}$ below the surface there is an upward flux of soil moisture and below $300 \mathrm{~cm}$ a downward flux of soil moisture." Note should be made that additional reversals of potential gradient appear to occur at depths between 4.4 and 23 meters.

Similar observations regarding soil-moisture in upper 4 meters have been made by ARHCO personnel at the psychrometer site located at the BNW meteorological station. Meteoric water from the first third of the water year (0ctober 1, 1970 to January 31,1971 ) was observed to remain stored essentially in the upper meter of soil for some time. As of January 31 , 1971, the water fronts from fall and early winter precipitation had not reached a depth of 50 centimeters, as evidenced by thermocouple psychrometer measurements at the meteorological station site. (22) During this period, moisture was observed to move upward from lower depths as a result of the steep thermal gradient upwards. As of January 15, 1971, the soil temperatures were $2^{\circ} \mathrm{C}$ at $35 \mathrm{~cm}, 8^{\circ} \mathrm{C}$ at $1.02 \mathrm{~m}$, and $14^{\circ} \mathrm{C}$ at 2.39 $M$ depth as measured at the meterological station site.

This is equivalent to an approximate temperature gradient of about $6{ }^{\circ} \mathrm{C}$ per meter for the first two meters of depth in the direction of water transport upward. In comparison, the geothermal gradient is only about $4^{\circ} \mathrm{C}$ per 100 meters of depth. Thus, there are seasonal driving forces based on temperature gradients near the surface and downward for several meters that are as much as 100 fold greater than the smaller but nearly constant geothermal gradient. These seasonal thermal gradients result from the annual sinusoidal nature of the curve of temperature versus time.

THERMOCOUPLE PSYCHROMETER AND TEMPERATURE MEASUREMENTS TO

THE WATER TABLE AT $32-49$ COORDINATES

The tritium studies indicated that meteoric water containing tritium contamination from the atmospheric testing 
of nuclear devices had not as yet penetrated below a depth of 7 meters for soil sampled at the sites tested. Support of these conclusions based on the thermocouple psychrometer measurements was not easily obtained. This has, in part, been the result of the need to perfect the technique of using this relatively new instrumentation for in situmeasurements. Difficulty was encountered in obtaining reliable thermocouple psychrometer values in the depth range of 4.4 to 18 meters, using the technique of implantation of psychrometer sensors in pipe casings produced by drilling dry wells. The small coring well at the $32-49 C$ site used by Enfield and Hsieh ${ }^{(36)}$ was limited to 4.4 meter depth due to inability to extract soil from a greater depth, using core drills. The site at the meteorological station appears to be located too close to the station and the psychrometer values at depths below 4.4 meters appear to be influenced by the water used for irrigation at the station.

In 1970, a larger $15 \mathrm{~cm}$ diameter well at the $D$ Site at the 32-49 Hanford coordinates was drilled to the water table using a dry core barrel technique and concentric casings as shown in Figure 11. The concentric casings were used in an effort to reduce the skin frictional forces which would be encountered in subsequent removal of the casing. The material which was removed during the driling process was labeled for depth, stored in PVC bags and sealed in metal cans to prevent the loss of soil moisture. To protect the instruments during the backfilling process, a PVC pipe was lowered into the $15 \mathrm{~cm}$ steel pipe. The instrument cable with soil thermocouple psychrometers and diode temperature transducers was lowered inside the plastic pipe. As well 32-49D was backfilled the plastic pipe and well casing were gradually removed, leaving the instruments in place.

The instrumentation included porous-cup-type soil 
thermocouple psychrometers (TCP). These were soldered to a shielded Beldon cable \#8640 (two conductor \#26 solid copper, color-coded vinyl jacket). Temperature sensors were diode temperature transducers (DTT). These were soldered to a Beldon coaxial cable (RG 174-U type, 50 ohms, 26 AWG strands). All TCP and DTT cables were bundled and taped together with a stainless steel cable $0.42 \mathrm{~cm}$ diameter into one cable. The stainless steel cable was used to carry the weight during the installation. Several instruments were lost during installation between the 12 and 21 meter levels when the clasp which held the instruments were caught by the casing as it was being removed. Future installations of this type should employ a different holding method to eliminate the possibility of severing instruments.

Table IV shows the soil size analyses at depths along the soil profile as determined by laboratory analysis of soil samples taken at the 32-49D site during dry drilling of the we11. Figure 12 shows the soil moisture profile expressed as weight percent water versus depth as determined by gravimetric laboratory analysis of the individual soil samples. Figure 13 shows water potential as a function of moisture content for a composite of the soil samples. (36) Figure 15 shows hydraulic conductivity and thermal diffusivity as a function of water potential based on desorption curves for the composite soil sample. Some question remains as to whether or not this composite is truly representative of the soil at the $32-49 D$ site.

The profile for the average monthiy values of in situ water potential for the months of May 1971, October 1971, and March 1972 is shown in Figure 14. The upper five meters have water potential values that show seasonal variation. There is a continuous change, however, for values in the depth range from 6 to 36 meters. In the depth range of 6 to 24 meters 


\section{TABLE IV}

\section{SOIL SEPARATES FOR PROFILE AT INSTRUMENT INSTALLATION IN WELL $32-49$}

\begin{tabular}{cr}
\multicolumn{2}{c}{ Depth } \\
\cline { 1 - 1 } Meters & Feet \\
\cline { 1 - 1 } 1.5 & 5 \\
3.0 & 10 \\
4.6 & 15 \\
6.1 & 20 \\
7.6 & 25 \\
9.2 & 30 \\
10.7 & 35 \\
12.2 & 40 \\
13.7 & 45 \\
15.3 & 50 \\
16.8 & 55 \\
18.3 & 60 \\
19.8 & 65 \\
20.4 & 70 \\
23.9 & 75 \\
24.4 & 80 \\
26.0 & 85 \\
27.5 & 90 \\
29.0 & 95 \\
30.5 & 100 \\
32.1 & 105 \\
33.6 & 110 \\
35.1 & 115 \\
36.6 & 120 \\
38.1 & 125 \\
39.6 & 130 \\
41.2 & 135 \\
42.7 & 140 \\
44.2 & 145 \\
46.8 & 150 \\
47.3 & 155 \\
48.8 & 160 \\
50.3 & 165 \\
51.8 & 170 \\
53.4 & 175 \\
54.9 & 180 \\
56.4 & 185 \\
58.0 & 190 \\
59.5 & 195 \\
61.0 & 200 \\
62.5 & 205 \\
64.0 & 210 \\
65.6 & 215 \\
67.1 & 220 \\
68.6 & 225 \\
70.2 & 230 \\
71.7 & 235 \\
73.2 & 240 \\
& \\
& \\
13
\end{tabular}

\begin{tabular}{r} 
\% Sand \\
\hline 95.1 \\
99.6 \\
98.7 \\
92.3 \\
81.9 \\
89.2 \\
90.2 \\
90.7 \\
90.9 \\
83.7 \\
78.9 \\
90.6 \\
67.6 \\
83.6 \\
82.4 \\
73.8 \\
93.7 \\
84.4 \\
92.9 \\
94.2 \\
89.5 \\
86.4 \\
90.5 \\
84.7 \\
91.2 \\
85.6 \\
90.9 \\
83.9 \\
80.0 \\
84.9 \\
89.3 \\
84.3 \\
84.5 \\
89.6 \\
89.0 \\
85.0 \\
84.8 \\
86.8 \\
92.8 \\
90.0 \\
91.9 \\
80.4 \\
61.8 \\
81.8 \\
86.0 \\
85.5 \\
89.5 \\
55.9 \\
92.9 \\
\end{tabular}

$\%$ Silt

3.3

0.2

4.6

16.7
9.4

8.4

7.9

6.7

12.8

18.6

6.9

28.4

12.9

13.8

21.2
4.7

12.8

5.3

12.0

8.7

10.7

7.6

12.0

7.0

11.7

6.8

13.9

15.6

12.6

8.5

13.0

12.8

8.2

8.8

12.5

12.5

10.3

5.7

7.5

6.7

14.7

33.1

14.3

12.5

11.0

9.1

35.9
\% clay

1.6

1.6

3.1

1.4

1.4

1.4

1.4
2.4

3.5

2.5

2.5

4.0

3.5

3.8

5.0

1.6

2.8

1.8

3.8

1.8

2.9

1.9

3.3

1.8

2.7

2.3

2.3

4.4

2.5

2.2

2.7

2.7

2.2

2.2

2.5

2.7

2.9

1.5

2.5

1.4

4.9

5.1

3.9

1.5

3.5

1.4

8.2 
the in situ water potential values are becoming more negative indicating that the soil is becoming drier. The zone from 24 to 38 meters is becoming slightly wetter, but there is little change in the zone between 42 meters and the water table where the water potential is about -1.6 bars.

After installation of the transducers at the $32-490$ site the sensors were read periodically to determine when the soil reached equilibrium with the undisturbed soil. Figure 16 shows the temperature profile for this site as measured October 13, 1970. Figure 17 shows average temperature profiles for three months: May 1971; October 1971; and March 1972. The general overlap of values in Figure 17 from a depth of 6 meters to the water table (at about 92 meters) indicates that the temperature of the soil in this zone has essentially reached equilibrium. The approximate temperature gradient in the zone from a depth of 6 to 92 meters is $17.4^{\circ}+0.035 \mathrm{~d}$ where $d$ is the metric depth below the surface. This gradient does not apply to the seasonal zone above a 6 meter depth where the temperature depends upon the annual sinusoidal cyclic temperature curve for the particular depth and time of the year.

Figure 18 shows temperature curves versus time for three depths at the $32-49 D$ site. The sinusoidal shape of the temperature curve is quite obvious for the depth of 3 meters but is damped out to an essentially constant temperature at 30 meters and 87 meter depths.

\section{GEOTHERMAL GRADIENT AND SEASONAL TEMPERATURE CYCLES}

After installation of the transducers at the 32-49D site, temperature readings were recorded at various soil depths from a period of February 1971 to April 1972. Plots of temperatures at various depths as a function of time were made as shown in Figure 18 and the average monthly temperature for 
each depth was calculated. Although the temperature sensors were reportedly calibrated within $0.5^{\circ} \mathrm{C}$, several irregularities in the temperature profile curves were observed that may indicate errors in calibration of several of the sensors. The temperature scales were adjusted for selected depths by taking the temperatures at these depths over a period of one year and using these data to determine an average temperature versus depth. This assumes a constant heat flux upwards from the water table to the surface, a constant thermal diffusivity for soil at all depths and is recognized as an approximation. Table $V$ lists the results of the computer run. The resulting equation for the temperature gradient is:

$$
\mathrm{Tg}=17.4+.035 \mathrm{~d}
$$

where $\mathrm{d}$ is the depth in meters and $\mathrm{Tg}$ is the temperature, ${ }^{\circ} \mathrm{C}$, of the soil at a depth $d$.

Soil temperatures versus time at different depths are shown in Figures $\mathrm{C}-2$ through $\mathrm{C}-7$ in Appendix $\mathrm{C}$. Curves are shown in pairs for successive depths. Figure $C-1$ shows a pair for the depths of 6.1 and 30.5 meters. Because of the geothermal gradient the average temperature $\left(18.4^{\circ} \mathrm{C}\right)$ is higher at 30.5 meters than at 6.1 meters below ground surface. The curve for a depth of 6.1 meters has an obvious sinusoidal shape with a mean of $17.6^{\circ} \mathrm{C}$. The maximum temperature at the 6.1 meters depth occurs during December, indicating it is about one-half year out of phase with the maximum temperature at the surface. Overlapping regions indicating reversals in the thermal driving forces are shown in the other profile curves. When the thermal driving force alters direction, the tendency for moisture transport by temperature gradient also changes direction. By observing these curves it is possible to predict in which direction moisture will have a tendency to move as a result of thermal driving forces and during which period of time these tendencies will change. 
TABLE V

LEAST SQUARE CALIBRATION

(RESULTING EQUATION - TEMPERATURE GRADIENT $=17.4+0.35 \mathrm{~d}$ )

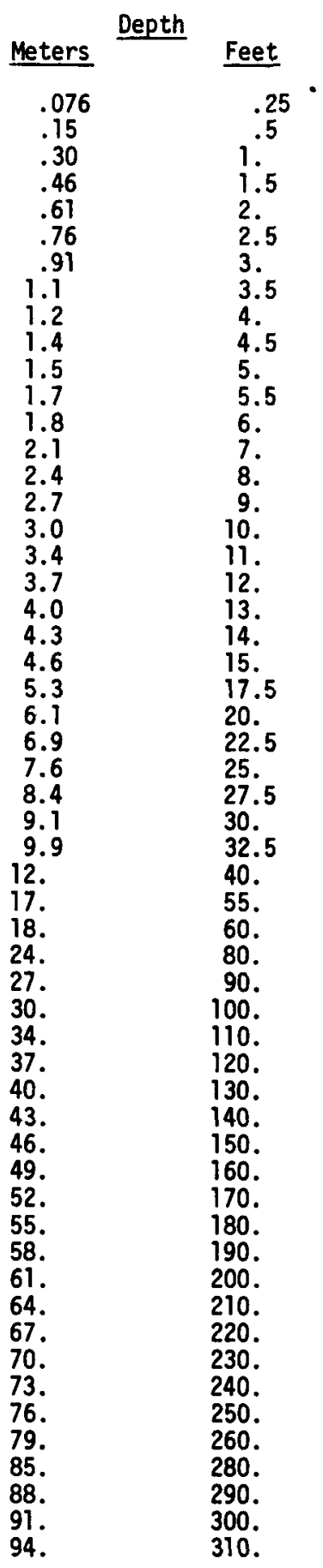

Temperature $\left({ }^{\circ} \mathrm{C}\right)$

Experimental Calculated

18.56

17.375

16.67

17.3776

22.09

16.85

17.3829

16.82

24.85

17.3882

17.3936

17.55

17.3989

21.28

16.53

17.4042

16.55

17.4095

18.91

17.4148

16.13

17.03

16.33

18.25

17.2

16.44

16.5

18.92

17.15

16.32

16.82

16.52

17.4201

17.4254

17.4307

17.436

17.4466

17.4573

17.4679

17.4785

17.4891

17.4997

17.5103

17.521

17.5316

17.5581

$17.43 \quad 17.5847$

16.94

17.25

17.07

16.41

15.9

16.6

17.9

16.6

17.3

17.4

17.8

18.3

18.4

19.

19.3

17.6112

17.6377

17.6643

17.6908

17.7174

17.797

17.9563

18.0093

18.2217

18.3278

18.434

18.5402

18.6464

18.7525

18.8587

18.5

18.5

18.9649

19.071

19.1

19.3

19.1772

19.2834

18.8

17.2

20.9

19.3895

19.4957

19.6019

18.7

20.5

19.7081

19.8142

20.

21.2

19.9204

20.0266

20.

22.7

20.8

21.1

20.1327

20.3451

20.4513

20.5574

20.1

20.6636 
The temperature profile in the soil is influenced by several factors. In the 200 areas the temperature at the water table in undisturbed sites is relatively constant at about $20^{\circ} \mathrm{C}$ the year around. From the water table upward to within about six meters from the surface the temperature profiles based upon measurements obtained during 1971-1972 is determined by the geothermal gradient with the temperature $\mathrm{Tg}=17.4^{\circ} \mathrm{C}+0.035 \mathrm{~d}$, where $d$ is the depth in meters from the surface. A second influence, the annual cyclic sinusoidal temperature curve, is superimposed on the geothermal gradient. Its influence is significant from a depth of about six meters to the surface and has the general form:

$$
T(d, t)=A \sin (B+C t)+T g
$$

where $T$ is the average monthly temperature at a particular depth for a particular month, $A$ is the amplitude of the sine wave, $B$ is the shift of the sine wave from the time origin, $\mathrm{Tg}$ is the temperature from the geothermal gradient, and $t$ is the time in months after February. The minimum average air temperature based on averages of 30 years is reached about the third week in January. The minimum average soil temperature at a depth of one meter is reached about one month later. Thus February is a suitable month for zero time on the annual cyclic sinusoidal temperature curve as the minimum temperature in the upper meter of soil usually occurs in February.

There is a third minor influence on the temperature profile termed the diurnal effect (see Appendix $D$ ). The diurnal effect is caused by the changes in temperature on a daily basis and only influences the soil temperature down to a depth of a few centimeters. If one wishes to use temperature profile calculations for the top layer of soil the dirunal effect must be taken into consideration. Once the depth of a few centimeters has been reached the temperature influence of the diurnal effect dissipates. 
A fourth factor which influences the soil temperature (on a noncyclic basis) down to a depth of approximately one meter are the nonseasonal variations from normal climatic conditions which occur randomly. An unusually warm or cold wave for a specific time period may alter the normal temperature profile. These irregular perturbations from the normal temperature profile alter values near the surface as in the case of the diurnal effect, but become insignificant at lower depths.

The last two factors mentioned are not included in the equation for the temperature profile in the soil since their influence can be predicted only on an average basis. A method for predicting temperature profile in cases where the soil temperature follows a noncyclic pattern can be found in Appendix E.

The value of $\mathrm{Tg}$ in Equation 2 is simply $17.4+0.35 \mathrm{~d}$, where is the equation of the average geothermal temperature profile mentioned earlier. A, the amplitude of the sinusoidal wave, must be of an exponentially decaying (dampening) form since it is observed that the amplitude of the sine wave rapidly decreases in magnitude as the depth becomes greater. The value of $A$, therefore, takes the form of:

$$
A=A_{1} e^{-B_{1} d}
$$

where $A_{1}$ and $B_{1}$ are constants whose values were determined from experimental data to be 17.8 and 0.5 , respectively.

The value of $B$, a factor that takes into consideration that the sine wave does not begin its cycle at $t=0$, changes as the depth varies. Since $B$ is a function of depth, it takes the form:

$$
B=A_{2}+B_{2} d
$$

$A_{2}$ and $B_{2}$ have been determined to be -65 and -24.3 , respectively. The constant $C$ has the value of 30 . 
Substituting the above values into Equation 1 yields:

$T(d, t)=17.8 e^{-.5 d} \sin (30 t-65-24.3 d)+0.035 d+17.4$

Two examples using this equation are given.

Example 1:

$$
\begin{aligned}
& \text { Let } \begin{aligned}
d & =1.8 \text { meters } \\
t & =2(\text { Aprit })
\end{aligned} \\
& T=17.8 \mathrm{e}^{-.5(1.8)} \sin (30 \times 2-65-24.3 \times 1.8)+0.035 \times 1.8+17.4 \\
& =(7.24) \times(-0.742)+.063+17.4 \\
& =12.1^{\circ} \mathrm{C}
\end{aligned}
$$

Example 2:

$$
\begin{aligned}
& \text { Let } \begin{aligned}
d & =4.0 \text { meters } \\
& t=8 \text { (October) } \\
T= & 17.8 \mathrm{e}^{-.5(4)} \sin (30 \times 8-65-24.3 \times 4)+0.035 \times 4+17.4 \\
= & (2.41) \times(.988)+.14+17.4 \\
= & 19.9^{\circ} \mathrm{C}
\end{aligned}
\end{aligned}
$$

as compared to $20.0^{\circ} \mathrm{C}$ in Figure $\mathrm{C}-2$.

A more elaborate moisture transport-depth-time phase diagram is shown in Figure 19. The purpose of the figure is to provide an overall concept of the direction and magnitude of the thermal driving force as a function of time and depth. Table VI lists the values found in Figure 19 and their corresponding thermal drive force.

Depth variations were chosen to be 0.25 meters and the time increments are four per month. The magnitudes of the driving force were determined by calculating the temperatures at 0.25 meters above and below the selected depths. These temperatures, based on values given by Equation 2, were then compared and a value from -9 to +9 was assigned for that depth based upon the magnitude of their temperature difference (-9 resents a large driving force downwards, etc.). The magnitude of the thermal driving force varies greatly at the upper levels near the surface of the soil. This result can be expected 


\section{$\underline{\text { TABLE VI }}$}

\section{VALUES SHOWN IN FIGURE 19 AND CORRESPONDING DRIVING FORCES}

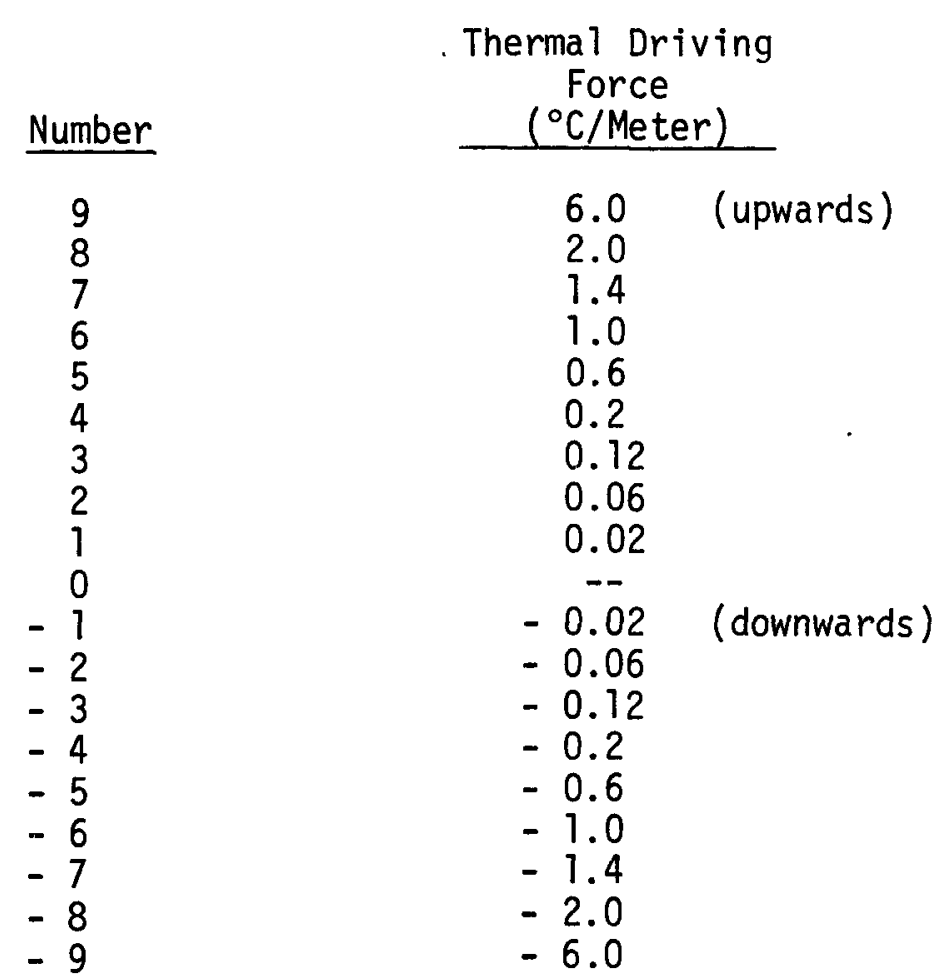

since the amplitude of the temperature fluctuations is largest near the surface. As greater depths are reached the magnitude of the thermal driving force is dissipated below a depth of approximately 10.5 meters. Below this depth, only a slight upward thermal driving force exists from the geothermal fradient.

C. W. Rose ${ }^{(37)}$ discusses the general features of the propagation of the waves of temperature into the soil due to the periodic seasonal fluctuations of temperature. He assumes that the soil may be considered as a semi-infinite medium of uniform thermal diffusivity. The equation of heat 
conduction is:

$$
\frac{\partial T}{\partial t}=k \frac{\partial^{2} T}{\partial x^{2}}
$$

Using this relationship together with the assumption that the temperature of the soil is a sinusoidal periodic function of time, yields an expression for the decrease in amplitude of the sine wave in the form of $\exp \left[-z(\omega / 2 k)^{1 / 2}\right]$. In an example given by Rose the value of $(\omega / 2 k)^{1 / 2}$ reduces to 0.45 , thus the expression becomes exp[-0.45z) where $z$ is the depth in meters. This expression agrees remarkably well with the expression exp[-0.5d] that was obtained from our experimental data and given in Equation 2.

The term $k$ is the thermal diffusivity of the medium and $\omega$ is the value obtained by dividing $2 \pi$ by the number of cycles per time period.

With the same assumptions, the speed of the propagation of the temperature wave, also discussed by Rose, is given by:

$$
V=(2 k \omega)^{1 / 2}
$$

Using the data discussed earlier a value of $1.26 \mathrm{~m}^{2} /$ year (or $0.004 \mathrm{~cm}^{2} / \mathrm{sec}$ ) for $k$, the thermal diffusivity, is obtained and the value for $\omega$ is 6.28 /year. A value of $V$ is therefore calculated as follows:

$$
\begin{aligned}
V & =(2 \times 12.6 \times 6.28)^{1 / 2} \\
& =(158)^{1 / 2} \\
& =12.6 \text { meters per year } \\
& =1.05 \text { meters per month }
\end{aligned}
$$

Based on these data the sinusoidal profiles penetrate downward into the soil at a rate of 1.05 meters per month.

\section{THE LYSIMETER EXPERIMENT}

The difficulties encountered with installing thermocouple psychrometers using cored or drilled holes indicated need for 
a better technique. A lysimeter experiment was designed to improve measurement capability and to provide flexibility for a variety of experiments.

The lysimeters shown schematically in Figure 20 may be visualized as cylinders of vadose zone soil, three meters in diameter by 20 meters deep, isolated by the lysimeter walls from the complexing influences of possible horizontal moisture transport. The lysimeters are equipped with redundant soil moisture measuring devices instead of an actual weighing balance in order to circumvent the difficulties of weighing. Each of the lysimeters has three aluminum tubes for neutron probe access for soil moisture content measurements and three instrumented cables with "dry-bulb" thermocouples and "wetbulb" thermocouple psychrometers. In addition, a bundle of small diameter stainless steel tubing was installed for measuring atmospheric pressure at various soil depths.

The soil removed during excavation was mixed several times in a batch plant and was carefully returned to the lysimeters to avoid differential layering. In order to have meaningful information it was essential to excavate the caisson down to a depth of about 20 meters so as to include the driest zone, which occurs from about 10 to 17 meters below ground surface.

If the input of annual meteoric water to soil were continually greater than the outgoing evaporation and evapotranspiration, then there would be a net accumulation of water in the soil. No matter how small the amount of this annual excess, in time, water would eventually percolate downward. A closed-bottom lysimeter was provided to trap and measure accumulation if it occurs. If the outgoing water exceeds the input of annual meteoric water, a net desiccation would develop in the upper soil horizons below the climatic seasonal zone. The second lysimeter has an open bottom so that communication 
and/or exchange of soil moisture can take place with the soil below. If percolation to a depth of 15 meters or more should occur, the moisture content in the soil above the bottom of the closed lysimeter would be greater than in the lysimeter. If on the other hand, the water removed by evaporation should exceed the annual precipitation, the zone above the closure would become drier. In that case percolation to the water table from the surface could not occur.

Figures 21 and 22 show the moisture profile in the closedbottom 1ysimeter for September 1973 and November 1972 and 1973, respectively. Note may be made of the development of a partially desiccated zone above three meters in September (Figure 21) as a result of the hot, dry summer 1973. Figure 22 shows the effect of a very heavy precipitation in the autumn of 1973. The effect so far is limited to the upper 1.5 meters. Figure 22 also shows that the moisture content in the upper three meters was greater in November 1972 than in November 1973. This has been ascribed to the higher rainfall during the summer 1972. 
FUTURE WORK

A partial understanding has been gained of soil moisture relationships in the vadose zone of a semi-arid site such as the Hanford reservation. The existence of a partially desiccated zone has been indicated in all approaches. On refilling the closed bottom lysimeter with well mixed soil, the partially desiccated zone and the seasonal zone were removed by mixing. Precipitation during refilling actually increased the moisture content in the upper 5 meters of soil compared to that below. Not only has this excess moisture been removed by the warm, dry spring and summer of 1973, but a partially desiccated zone at depths of 2 to 5 meters is beginning to develop. This trend must be observed for a longer period of time to determine if indeed a partially desiccated zone develops below the seasonal zone in soil free of stratification and without an initial desiccated zone.

These studies must be augmented with measurements of water potential of the soil in both lysimeters as a function of depth and time. These values may then be compared with those obtained from the naturally stratified soil at the 2 D site with 32-49 Hanford coordinates. Also, the barometric pressure at various depths in the lysimeter soil must be measured as a function of time and depth. Comparision with the atmospheric pressure will determine the extent of moisture removal by barometric pressure pumping. These measurements can best be made by completion of the instrument room at the lysimeter site and connection of the sensors already installed in the lysimeters to appropriate instruments and recorders.

Additional new sensors and instrumentation will be required to permit measurement of solar input radiation, annual precipitation at the site, evaporation and advection losses at the lysimeters. Knowledge of these values would 
permit the computation of complete heat and water balances at the lysimeter site. This will permit a check to be made on the disposition of the annual meteoric precipitation and thereby determine by another method whether or not some of the water is transported to the underground water.

The belief at present is that on the semi-arid Hanford reservation, water does not percolate to the underground water in vadose zones high above the water table, free of ponding and collection of water from surface runoff. If the annual precipitation increases, there is some critical value, ${ }_{C}$, of precipitation above which percolation to the underground water table will occur. This factor should be studied possibly using artificial rainfall experiments to determine the value of $P_{C}$ for water to percolate to the underground water.

In addition to the physical measurements, the theory of soil-water phenomena must be studied further with particular reference to the influence of temperature on water potential and water transport. 


\section{SUMMARY AND CONCLUSIONS}

Soil-moisture relationships are being studied for selected soils on the Hanford reservation to determine whether or not water from meteoric precipitation percolates to the underground water in vadose zone soil high above the deep water tables. The purpose is to establish with greater certainty the ultimate disposition of radionuclide products stored on the Hanford reservation. Observations to date indicate that the annual precipitation of meteoric water does not necessarily percolate downward through the vadose zone to the water table but may move downward only a few meters during the spring of the year and be removed by evaporation and evapotranspiration during the summer. Tritium analyses of soil moisture were used to explore the phenomenon by evaluating tritium distribution from atmospheric fallout versus soil depth.

Soil samples were recovered in 1970 from the dry drilling of wells on the Hanford site. Special techniques were used in the collection procedure to avoid contamination of soil samples with tritium from the atmosphere. Water was recovered from the soil samples by distillation and the very low tritium concentration in some samples was electrolytically increased by a factor of about 100 to permit more accurate gas counting. This technique was developed by the Teledyne Isotope, Inc. Laboratory who conducted the analyses. The results successfully demonstrated that archaic water exists in virgin soil at depths from 7 meters to the water table, indicating that percolation has been limited to lesser depths. Data for tritium analysis of water from soil samples taken from the test well may be considered to be a classic example of tritium distribution vertically in virgin areas of the vadose zone of Hanford soils. The tritium concentration decreased exponentially from the surface to a depth of 5 meters. The 
concentration ranged from $1490 \pm 50$ tritium units at the surface to $17.1 \pm 0.9$ TU at a depth of 5 meters. The tritium concentration from a depth of 7 meters to the water table was found to be 4.9 TU or less. These low values are in the range of values associated with archaic water and water isolated from atmospheric contamination for the past 25 or more years; predating atmospheric testing of nuclear weapons. To investigate these phenomena further other parameters of the soil moisture profile were studied.

The movement of soil water downward is influenced by the soil temperature. A decrease in temperature during autumn and winter increases the surface tension of water in the capillaries of the soil. This increases the radius of curvature and therfore, the volume of the miniscuses of water held at the points of soil-particle contact. This is one reason for the rise of soil moisture from a low value after a decrease in temperature. A low temperature near the surface provides a holding system that prevents transport of water downward in autumn and winter.

The reversal of temperature differences in spring and summer tend to transport water downward by the influence of temperature gradient as well as by gravity and capillary transport. A second effect of the seasonal increase in temperature is an increase in the upward removal of water by diffusion. Downward transport usually begins after melt of the winter frost which releases water and progresses downward as heat passes into the soil releasing water previously held there by capillarity and lower temperatures. This release serves to move the water front down more rapidly during February, March, and April. However, diffusion processes restrains this downward transport. Temperature gradients in autumn and winter tend to move water from depths toward the surface except for a short period during February and possibly March. During late spring 
and summer the temperature gradients in the soil near the surface reverses but upward transport of water by surface evaporation and upward capillary flow, evapotranspiration, and diffusion negates the mechanisms for downward percolation.

Measurements on the Hanford reservation have shown that the upward transport zone penetrated to a depth of three meters as early as March 5. The front for upward migration moves rapidly downward with the approach of summer, overtaking the descending front for downward percolation. The upward transport of water is considered to be the principle reason for the drier zone at depths of 7 to 17 meters at the site of the test well. Other factors such as soil breathing as a result of changes in atmospheric pressure are considered to be involved, but are believed to exert a minor influence.

To explore further the factors controlling the absences of transport of water to the water table at the arid Hanford test site other studies have been initiated. These include study of temperature and water potential from the surface to the water table over a depth of 100 meters, and the study of changes in soil moisture over a depth of 20 meters in two large lysimeters 3 meters in diameter and 20 meters deep. One lysimeter is open at the bottom, the other is closed. About two years after installation, the lysimeters indicate a slow loss of moisture in the lower zones from 3 to 20 meter depths and the development of a partially desiccated zone.

The potential forces for water transport in arid soils also are being evaluated from the theory of thermodynamics. Present results indicate the existence of potential forces previously neglected that have greater importance in arid soils than in irrigated soils.

This work has shown that there is a critical rainfall that is required to cause moisture to percolate to the water 
table. Further studies are showing that commonly accepted equations in hydrology that assume isothermal conditions are not generally applicable in arid or semi-arid regions having a deep water table. Indeed, temperature may become the primary driving force for water transport in the more arid soils.

\section{REFERENCES}

1. D. J. Brown, "Migration Characteristics of Radionuclides Through Sediments Underlying the Hanford Reservation, Disposal of Radioactive Wastes into the Ground," Proc. Symp. Vienna, 1967 IAEA, Vienna, 215 (1967).

2. S. J. Beard and W. L. Godfrey, "Waste Disposal into the Ground at Hanford, Disposal of Radioactive Wastes into the Ground, Proc. Symp. Vienna, 1967 IAEA, Vienna, 123 (1967).

3. J. E. Galley, et al., "Report of Committee on Geologic Aspects of Radioactive Waste Disposal," Nat. Acad. Sci., Nat. Res. Counci1, Wash. D.C., (May 1966).

4. "Disposal of Radioactive Waste on Land," publ. 519, National Academy of Sciences - National Research Council, Washington D.C., (1957).

5. L. von Erichsen, "Storage of Radioactive Waste in Arid Areas," Atomkernenergie, 4, 112-115, (1959).

6. D. E. Jenne, W. A. Stone, and J. M. Thorpe, "Climatography of the Hanford Area," BNW-1605, Battelle Pacific Northwest Laboratories (1972).

7. U. S. Army Corps of Engineers, "Water Resource Development of the Columbia River Basin," Volume I, June, (1958).

8. E. C. Childs, "An Introduction to the Physical Basis of Soil Water Phenomena," Wiley, New York (1969). 
9. L. A. Richards, and M. Fireman, "Pressure Plate Apparatus for Measuring Moisture Sorption and Transmission by Soils." Soil Science, 56,395 (1943).

10. J.W. Cary, "Water Flux in Moist Soil: Thermal Versus Suction Gradiants," Soil Science, 100, 168 (1965).

11. W. R. Gardner, "Soil Water Relationships in Arid and Semi-Arid Conditions: Plant-Water Relationships in Arid and Semi-Arid Conditions," UNESCO, Place de Fontenoy, Paris, 37 (1960).

12. J. W. Cary and S. A. Taylor, "Thermally Driven Liquid and Vapor Phase Transfer of Water and Energy in Soil," Soil Sci, Proc.; 417 (1962).

13. D. Zaslavsky and I. Rovina, "Review and Some Studies of Electrokinetic Phenomena," Moisture Equilibria and Moisture Changes In Soils (Proc. Symp. in Print), Butterworths, Australia, 55 (1965).

14. W. D. Kemper, "Water and Ion Movement in Thin Films as Influenced by Electrostatic Charge and Diffuse Layer of Cations Associated with Clay Mineral Surfaces," Soil Sci. Soc. Amer. Proc. 24, 10 (1960).

15. R. L. Harlin, "Analys is of Coupled Heat-Fluid Transport in Partly Frozen Soil," Water Resources Res. 9 5, 1314 (1973).

16. U. Zimmerman, 0. Ehhalt, and K. 0. Munnich, "Isotopes in Hydro1." (Proc. Symp. Vienna, 1966) IAEA, Vienna 567 (1967).

17. U. Zimmerman, K. O. Munnich and W. Roether, "Isotope Tech. Hydrol. Cycle," (Proc. Symp. U. of I11., 1965) Geophys. Monograph No. 11, AGU, Wash., D.C. 28 (1967).

18. D. B. Smith, P. L. Wearn, H. J. Richards, and P. C. Rowe, "Isotope Hydrol." 1970 (Proc. Symp. Vienna, 1970) IAEA, Vienna 73 (1970). 
19. B. L. Schmalz and W. L. Polzer, "Tritiated Water Distribution in Unsaturated Soil," Soil Sci. 108 I 43 (1969).

20. B. G. Richards, "Moisture Flow and Equilibria in Unsaturated Soils for Shallow Foundations," Permeability and Capillarity of Soils ASTM STP 417, Am. Soc. Testing Mats., Philadelphia 4 (1967).

21. B. G. Richards, "Moisture Equilibria and Moisture Change

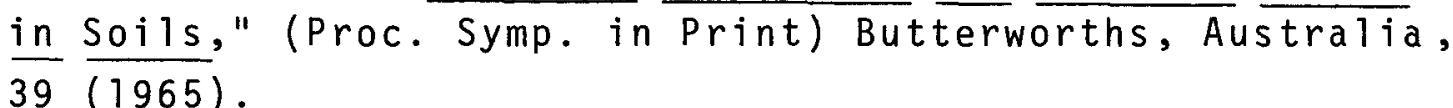

22. R. E. Isaacson, et al., "Soil Moisture Transport in Arid Site Vadose Zones," $\overline{A R H}-S A-169$, Atlantic Richfield Hanford Company (January 1974).

23. W. F. Libby, "Atmospheric Helium Three and Radiocarbon from Cosmic Radiation," Phys. Rev. 69, 671 (1946).

24. V. Faltings and P. Harteck, "Tritium Content of the Atmosphere," $\underline{\text {. Naturforsch, }}$ 5a, 428 (1950).

25. A. V. Grosse, W. H. Johnston, R. L. Wolfgang, and W. F. Libby, "Tritium in Nature," Science, 113, 1 (1951).

26. H. E. Suess, "Tritium Geophysics as an International Research Project," Science, 163, 1405 (1969).

27. D. Lal, "On Investigations of Geophysical Processes Using Cosmic Ray Produced Radioactivity," Earth Science and Meteroitics, 115 Interscience Publishers, New York, (1963).

28. F. Bergemann, "New Determination of Rates of Disintergration of Terrestrial and Natural Tritium. Origin of Natural Tritium," $\underline{Z}$. Naturforsch, 14a, 334 (1959).

29. D. Lal and B. Peters, Progress in Elementary Particles, Amsterdam, 9 (1962). 
30. E. Teller, W. K. Talley, G. H. Higgins, and G. W. Johnson, "The Constructive Uses of Nuclear Explosives," McGrawHill Book Co., New Jersey (1968).

31. H. Schultz, "Tritium Measurement Services at Isotopes," (Brochure of Isotopes) A Teledyne Co., Westwood, NJ (1969).

32. D. D. Rabinowitz and G. W. Gross, Environmental Tritium As a Hydrometerologic Tool in the Roswell Basin, New Mexico, WRR 1 Report No. 016, New Mexico Water Research Institute, New Mexico State University, Las Cruces, New Mexico (1972).

33. B. Bosch, et al., "Geodynamics - The Cycle of Tritium in the Atmosphere - Hydrosphere at Mean Latitudes after 1952," Compte Rendus Acad. Sci. Paris, 270, Series D, 267 (1970).

34. J. M. Hales, Scavenging of Gaseous Tritium Compounds by Rain, BNWL-1659 Battelle Pacific Northwest Laboratories (1972).

35. J. Tadmor, "Deposition of ${ }^{85} \mathrm{Kr}$ and Tritium Released from a Nuclear Fuel Reprocessing Plant," Health Physics, 24, 37 Pergamon Press, (1973).

36. C. G. Enfield and J.J.C. Hsieh, Application of Thermocouple Psychrometers to Soil Water Transport,BNWL-SA-3692 Battelle Pacific Northwest Laboratories (1970). Water Resources Research, 7, No. 5, 134 (1971).

37. C. W. Rose, Agricultural Physics, Pergamon London, 30 (1969).

38. R. Geiger, The Climate Near The Ground, Harvard University Press, Cambridge, Mass. (1966).

39. J. Crank, The Mathematics of Diffusion, Claredon Press, oxford, England (1956). 
This page is intentionally blank 


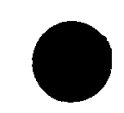

\section{APPENDIXES}


APPENDIX A

COMMENTS FROM THE NATIONAL ACADEMY OF SCIENCE

NATIONAL RESEARCH COUNCIL $(3,4)$

\section{CONCERNING PERCOLATION}

"The protection afforded by aridity can lead to overconfidence: At both sites (Hanford and NRTS) it seemed to be assumed that no water from surface precipitation percolated downward to the water table, whereas there appears to be as yet no conclusive evidence that this is the case...."

:The movement of fluids through the vadose zone and the consequent movement of the radioisotopes are not sufficiently understood to insure safety...."(3)

\section{CONCERNING THE STORAGE OF WASTES}

"The most promising method of long-term storage of highlevel fission product wastes at the present time seems to be in salt deposits. . ."

"The second most promising method seems to be in forming silicate brick or slag which would hold all radionuclides in virtually insoluble blocks. These could be stored in sheds (shielded) on (or near) the surface in arid areas or in dry mines." (4)

In 1965, the Committee commented regarding storage at arid sites (pages $10,67,71$, and 82 of reference 3 ). "The Committee was concerned over the prevailing belief that the unconsolidated soil, sand, and gravel that comprise the surficial materials to a depth of several hundred feet provide a reservoir for safe storage of tremendous quantities of wastes of all levels of radioactivity, and that no hazardous amounts of radioactivity will percolate down to the water table. The inadequacy of present understanding of hydrology in unsaturated earth materials (the vadose zone) was generally 
recognized.." (reference 3, page 10).

"The Committee is also dubious about the concept that in arid and semi-arid lands meteoric water does not percolate downward as far as the water table but instead is lost entirely by evaporation and plant transpiration. Operations conducted under this concept are saturating tangible volumes of soils with radionuclides, some of them long-lived, which in the course of a century or two may be carried to the water table by catastrophic "one-a-centry" deluges. Especially in areas having centripetal surface-drainage systems and where innumberable location topographic depressions collect runoff, contamination at or near the surface may be subject eventually to transportation downward to the water table in the event of a rare calamitous flood. The Committee is not aware of any past or present research that might aid in determining the extent of this risk. It is a field of investigation which should not be overlooked as a part of the research pertinent to ground disposals of long-lived radioactivity. . ." (reference 3 , page 67).

"Further in regard to the geohydrology at the semiarid sites in the Columbia Plateau, we reiterate our concern about the prevailing concept of the "dry soil" zone above the water table as a zone which is never completely penetrated by rain water or snow melt and which therefore is a safe container for absorbed radionuclides. We urge that AEC arrange for continuation and intensification of field investigations to determine the amount and rate of precipitation necessary to establish percolation to the water table in various types and thicknesses of soil and rock, both at Hanford and at NRTS. A study also should be made to determine the possible extent of upward movement of radionuclides to the root zone and thence to the surface along with water which reaches the surface and is transpired or evaporated..." (reference 3 , page 71 ). 
The Committee recommended that "The movement of water, both upward and downward, under varying conditions of wetting in the zone of aeration at NRTS and HAPO should be thoroughly studied, particularly with reference to questions about percolation of rain water and snow melt to the water table..." (reference 3 , page 82 ). 
This page intentionally blank 


\title{
APPENDIX B
}

\author{
Climatological Data \\ for Hanford (1971-1973)
}


TABLE B-1

WEATHER DATA DURING THE 1971-73 STUDY(6)

\begin{tabular}{|c|c|c|c|c|c|c|c|c|}
\hline \multirow[b]{3}{*}{$\begin{array}{l}\text { 돈 } \\
\text { 올 }\end{array}$} & \multicolumn{6}{|c|}{ Precipitation (CM) } & \multirow{2}{*}{\multicolumn{2}{|c|}{$\begin{array}{c}\text { Relative } \\
\text { Humidity }(\%)\end{array}$}} \\
\hline & & & & & Snow, & Ice Pellets & & \\
\hline & 㸃 & 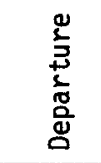 & 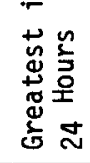 & 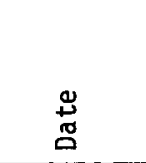 & \% & 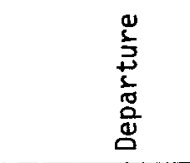 & 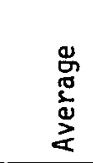 & $\begin{array}{l}0 \\
5 \\
5 \\
\frac{2}{2} \\
\frac{0}{8} \\
0 \\
0\end{array}$ \\
\hline \multirow[t]{2}{*}{$\begin{array}{l}J \\
F \\
M \\
A \\
M \\
J \\
J \\
A \\
S \\
0 \\
N \\
D\end{array}$} & $\begin{array}{r}1.98 \\
.25 \\
2.59 \\
.18 \\
1.42 \\
1.80 \\
.33 \\
.23 \\
2.87 \\
.46 \\
1.12 \\
2.72\end{array}$ & $\begin{array}{l}-0.51 \\
-1.35 \\
+1.37 \\
-0.76 \\
+0.15 \\
+0.36 \\
-0.03 \\
-0.25 \\
+2.12 \\
-1.02 \\
-0.99 \\
+0.53\end{array}$ & $\begin{array}{l}1.35 \\
0.15 \\
1.30 \\
0.15 \\
0.91 \\
0.99 \\
0.33 \\
0.23 \\
1.32 \\
0.41 \\
0.31 \\
0.81\end{array}$ & $\begin{array}{c}16 \\
9 \\
25-26 \\
24 \\
30-31 \\
2-3 \\
9 \\
22 \\
1-2 \\
29-30 \\
11=12 \\
8\end{array}$ & $\begin{array}{c}5.1 \\
T \\
1.5 \\
0 \\
0 \\
0 \\
0 \\
0 \\
0 \\
1.5 \\
T \\
20.6\end{array}$ & $\begin{array}{c}-8.4 \\
-4.6 \\
+0.3 \\
0 \\
0 \\
0 \\
0 \\
0 \\
0 \\
+1.5 \\
-2.8 \\
+10.2\end{array}$ & $\begin{array}{l}72 \\
62 \\
56 \\
43 \\
37 \\
41 \\
27 \\
30 \\
45 \\
51 \\
73 \\
78\end{array}$ & $\begin{array}{r}-4 \\
-8 \\
0 \\
-4 \\
-5 \\
+1 \\
-5 \\
-5 \\
+4 \\
-7 \\
0 \\
-2\end{array}$ \\
\hline & 16.00 & -0.38 & 1.35 & $\begin{array}{l}\text { Jan } \\
16\end{array}$ & 28.7 & -3.8 & $\begin{array}{c}\text { Dec } \\
8\end{array}$ & -3.5 \\
\hline \multirow[t]{2}{*}{$\begin{array}{l}J \\
F \\
M \\
A \\
M \\
J \\
J \\
A \\
S \\
0 \\
N \\
D\end{array}$} & $\begin{array}{l}.48 \\
.69 \\
1.47 \\
.25 \\
5.16 \\
1.68 \\
0.41 \\
1.42 \\
0.05 \\
T \\
1.40 \\
3.23\end{array}$ & $\begin{array}{l}-1.98 \\
-0.79 \\
+0.51 \\
-0.86 \\
+3.81 \\
+0.10 \\
+0.02 \\
+0.89 \\
-0.71 \\
-1.55 \\
-0.64 \\
+1.16\end{array}$ & $\begin{array}{l}0.23 \\
0.23 \\
0.56 \\
0.20 \\
3.53 \\
0.66 \\
0.13 \\
1.07 \\
0.02 \\
\mathrm{~T} \\
0.38 \\
0.63\end{array}$ & $\begin{array}{c}23-24 \\
4-5 \\
12 \\
11 \\
20-21 \\
23=24 \\
18+ \\
15 \\
22+ \\
29+ \\
3 \\
11-12\end{array}$ & $\begin{array}{r}12.4 \\
3.6 \\
.3 \\
T \\
0 \\
0 \\
0 \\
0 \\
0 \\
0 \\
T \\
18.3\end{array}$ & $\begin{array}{c}-0.4 \\
-0.4 \\
-0.4 \\
0 \\
0 \\
0 \\
0 \\
0 \\
0 \\
0 \\
-2.8 \\
+7.9\end{array}$ & $\begin{array}{l}70 \\
75 \\
61 \\
43 \\
48 \\
48 \\
34 \\
37 \\
45 \\
51 \\
88 \\
76\end{array}$ & $\begin{array}{r}-6 \\
+5 \\
+5 \\
-4 \\
+6 \\
+8 \\
+2 \\
+2 \\
+4 \\
-7 \\
+15 \\
-4\end{array}$ \\
\hline & 16.23 & -0.23 & 3.53 & $20^{\text {May }}-21$ & 34.5 & +2.0 & 56 & +2 \\
\hline \multirow[t]{2}{*}{$\begin{array}{l}J \\
F \\
M \\
A \\
M \\
J \\
J \\
A \\
S \\
O \\
N \\
D\end{array}$} & $\begin{array}{l}2.29 \\
0.53 \\
0.20 \\
T \\
0.61 \\
0.03 \\
T \\
0.05 \\
1.09 \\
4.37 \\
6.71 \\
5.13\end{array}$ & $\begin{array}{l}-0.18 \\
-0.94 \\
-0.76 \\
-1.12 \\
-0.74 \\
-1.75 \\
-0.38 \\
-0.48 \\
+0.33 \\
+2.82 \\
+4.67 \\
+3.07\end{array}$ & $\begin{array}{l}0.81 \\
0.38 \\
0.20 \\
T \\
0.20 \\
0.03 \\
T \\
0.03 \\
0.66 \\
1.63 \\
1.63 \\
1.12\end{array}$ & $\begin{array}{c}12 \\
10 \\
1 \\
19+ \\
23-24 \\
23 \\
20 \\
31+ \\
19 \\
31 \\
11-12 \\
20-21\end{array}$ & $\begin{array}{c}10.9 \\
4.3 \\
0 \\
0 \\
0 \\
0 \\
0 \\
0 \\
0 \\
3.8 \\
16.8 \\
19.1\end{array}$ & $\begin{array}{r}-2.5 \\
-0.3 \\
-1.3 \\
- \\
- \\
- \\
- \\
- \\
- \\
+3.8 \\
+14.0 \\
+8.6\end{array}$ & $\begin{array}{l}78 \\
76 \\
52 \\
40 \\
36 \\
35 \\
28 \\
31 \\
44 \\
59 \\
77 \\
82\end{array}$ & $\begin{array}{l}+2 \\
+6 \\
-4 \\
-7 \\
-6 \\
-5 \\
-4 \\
-4 \\
+3 \\
+1 \\
+4 \\
+2\end{array}$ \\
\hline & 21.0 & +4.55 & 1.63 & $11^{\text {Nov }}-12+$ & 54.9 & +22.4 & 53 & -1 \\
\hline
\end{tabular}


TABLE B-I I

TEMPERATURE AND MEAN SKY COVER DURING 1971-73 STUDY(6)

\begin{tabular}{|c|c|c|c|c|c|c|c|c|c|c|c|}
\hline & \multicolumn{9}{|c|}{ Temperature $\left({ }^{\circ} \mathrm{C}\right)$} & \multirow{2}{*}{\multicolumn{2}{|c|}{$\begin{array}{l}\text { Mean Sky } \\
\text { Cover } 1 \\
\text { (tenths) }\end{array}$}} \\
\hline & \multicolumn{4}{|c|}{ Averages } & \multicolumn{5}{|c|}{ Extreme } & & \\
\hline & $\begin{array}{l}\frac{5}{+} \\
\text { 올 }\end{array}$ & 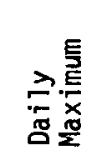 & $\underset{\frac{E}{E}}{\stackrel{E}{E}}$ & $\begin{array}{l}\frac{\lambda}{c} \\
\frac{1}{5} \\
\frac{0}{2}\end{array}$ & 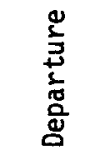 & 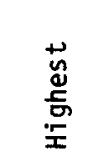 & $\underset{\Xi}{\mathbb{0}}$ & $\begin{array}{l}\text { 怘 } \\
\text { 章 } \\
\underline{J}\end{array}$ & $\underset{\mathbb{D}}{\stackrel{\Phi}{0}}$ & $\begin{array}{l}0 \\
0 \\
0 \\
\frac{0}{2} \\
\geq\end{array}$ & 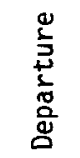 \\
\hline ๙ & $\begin{array}{l}J \\
F \\
M \\
A \\
M \\
J \\
J \\
A \\
S \\
0 \\
N \\
D\end{array}$ & $\begin{array}{r}7.2 \\
9.8 \\
11.2 \\
18.6 \\
25.5 \\
25.9 \\
34.8 \\
35.9 \\
24.1 \\
18.1 \\
9.6 \\
3.3\end{array}$ & $\begin{array}{r}-3.3 \\
-1.9 \\
-1.5 \\
3.7 \\
10.1 \\
11.0 \\
17.1 \\
17.9 \\
8.7 \\
3.8 \\
-0.3 \\
-4.9\end{array}$ & $\begin{array}{r}2.1 \\
3.9 \\
4.3 \\
11.1 \\
17.8 \\
18.5 \\
25.9 \\
26.9 \\
16.4 \\
10.9 \\
4.7 \\
-.8\end{array}$ & $\begin{array}{l}+3.4 \\
+2.0 \\
-2.1 \\
-0.8 \\
+0.9 \\
-2.3 \\
+1.3 \\
+3.5 \\
-2.1 \\
-0.8 \\
+0.2 \\
-1.1\end{array}$ & $\begin{array}{l}22.2 \\
18.9 \\
18.3 \\
24.4 \\
33.3 \\
37.2 \\
43.9 \\
44.4 \\
32.9 \\
29.4 \\
17.8 \\
10.0\end{array}$ & $\begin{array}{r}31 \\
13 \\
29 \\
6 \\
12 \\
22 \\
31 \\
9 \\
5 \\
4 \\
3 \\
21+\end{array}$ & $\begin{array}{r}-13.3 \\
-9.4 \\
-9.4 \\
-2.8 \\
2.2 \\
6.7 \\
6.7 \\
10.6 \\
3.3 \\
-10.6 \\
-6.1 \\
-15.0\end{array}$ & $\begin{array}{c}4 \\
6 \\
2+ \\
1 \\
20 \\
8 \\
6 \\
23 \\
21 \\
29 \\
5 \\
29\end{array}$ & $\begin{array}{l}8.1 \\
7.0 \\
7.1 \\
6.7 \\
6.0 \\
6.6 \\
2.5 \\
2.1 \\
3.5 \\
5.8 \\
7.4 \\
8.5\end{array}$ & $\begin{array}{l}+0.3 \\
-0.4 \\
+0.4 \\
+0.3 \\
+0.2 \\
+1.4 \\
-0.2 \\
-1.2 \\
-0.6 \\
-0.1 \\
-0.1 \\
+0.4\end{array}$ \\
\hline ลำ & & 18.7 & 5.1 & 11.9 & +0.2 & 44.4 & $\begin{array}{c}\text { Aug } \\
9\end{array}$ & -15.0 & $\begin{array}{l}\text { Dec } \\
29\end{array}$ & 5.9 & +0.4 \\
\hline$\underset{N}{N}$ & $\begin{array}{l}J \\
F \\
M \\
A \\
M \\
J \\
J \\
A \\
S \\
0 \\
N \\
D\end{array}$ & $\begin{array}{r}4.0 \\
6.7 \\
15.3 \\
17.2 \\
25.5 \\
28.4 \\
32.9 \\
33.8 \\
24.8 \\
18.9 \\
11.6 \\
2.2\end{array}$ & $\begin{array}{r}-5.7 \\
-3.5 \\
1.3 \\
2.3 \\
10.4 \\
.13 .5 \\
16.2 \\
16.8 \\
7.9 \\
3.6 \\
0.8 \\
-7.4\end{array}$ & $\begin{array}{r}-.8 \\
1.6 \\
8.3 \\
9.8 \\
17.9 \\
20.9 \\
24.6 \\
25.3 \\
16.3 \\
11.3 \\
4.4 \\
-2.6\end{array}$ & $\begin{array}{l}+0.6 \\
-1.4 \\
+1.6 \\
-1.6 \\
+1.4 \\
+0.3 \\
-0.2 \\
+1.7 \\
-2.7 \\
-0.4 \\
-0.2 \\
-3.2\end{array}$ & $\begin{array}{l}15.0 \\
20.0 \\
24.4 \\
25.6 \\
35.6 \\
36.7 \\
39.4 \\
43.3 \\
35.0 \\
28.3 \\
14.4 \\
18.3\end{array}$ & $\begin{array}{l}20 \\
27 \\
16-17 \\
27 \\
29 \\
28 \\
30+ \\
8 \\
4 \\
1 \\
5 \\
1\end{array}$ & $\begin{array}{r}-20.0 \\
-18.3 \\
-4.4 \\
-3.3 \\
2.2 \\
7.2 \\
10.0 \\
9.4 \\
-1.1 \\
-6.7 \\
-4.4 \\
-22.2\end{array}$ & $\begin{array}{r}28 \\
3 \\
25 \\
3 \\
1 \\
12 \\
9 \\
16 \\
27+ \\
30 \\
29 \\
10\end{array}$ & $\begin{array}{l}7.8 \\
8.2 \\
7.5 \\
6.3 \\
6.1 \\
6.3 \\
3.4 \\
2.1 \\
4.7 \\
4.9 \\
9.1 \\
7.1\end{array}$ & $\begin{array}{r}0.0 \\
+0.8 \\
+0.8 \\
-0.1 \\
+0.3 \\
+1.1 \\
+0.7 \\
-1.1 \\
+0.6 \\
-1.0 \\
+1.6 \\
-1.0\end{array}$ \\
\hline$N$ & & 18.1 & 4.7 & 11.4 & -0.3 & 43.3 & $\begin{array}{c}\text { Aug } \\
8\end{array}$ & -22.2 & $\begin{array}{l}\text { Dec } \\
10\end{array}$ & 6.1 & +0.2 \\
\hline$\stackrel{m}{\mathscr{n}}$ & $\begin{array}{l}J \\
F \\
M \\
A \\
M \\
J \\
J \\
A \\
S \\
0 \\
N \\
D\end{array}$ & $\begin{array}{r}2.8 \\
8.2 \\
15.4 \\
20.2 \\
25.9 \\
28.6 \\
34.6 \\
32.4 \\
26.2 \\
17.5 \\
7.1 \\
6.8\end{array}$ & $\begin{array}{r}-6.0 \\
-1.0 \\
1.7 \\
3.8 \\
8.7 \\
12.1 \\
16.8 \\
14.2 \\
11.2 \\
5.2 \\
0.1 \\
-0.1\end{array}$ & $\begin{array}{r}-1.6 \\
3.6 \\
8.6 \\
12.0 \\
17.3 \\
20.4 \\
25.7 \\
23.3 \\
18.7 \\
11.3 \\
3.6 \\
3.4\end{array}$ & $\begin{array}{l}-0.2 \\
+0.6 \\
+1.8 \\
+0.6 \\
+0.8 \\
-0.3 \\
+0.9 \\
-0.4 \\
-0.3 \\
-0.3 \\
-1.0 \\
+2.8\end{array}$ & $\begin{array}{l}10.6 \\
16.1 \\
20.0 \\
26.7 \\
36.7 \\
40.0 \\
41.1 \\
40.0 \\
36.7 \\
24.4 \\
16.7 \\
14.4\end{array}$ & $\begin{array}{c}17 \\
27 \\
25 \\
26 \\
14 \\
22 \\
15,29 \\
1 \\
11 \\
18 \\
28 \\
7\end{array}$ & $\begin{array}{r}-18.3 \\
-6.1 \\
-3.3 \\
-2.8 \\
1.1 \\
7.2 \\
7.8 \\
7.8 \\
6.1 \\
-18.3 \\
-8.9 \\
-10.0\end{array}$ & $\begin{array}{c}8 \\
8 \\
14 \\
8 \\
9 \\
18+ \\
1 \\
24 \\
26 \\
9 \\
4 \\
31\end{array}$ & $\begin{array}{l}7.4 \\
7.5 \\
6.9 \\
5.6 \\
4.8 \\
6.3 \\
2.2 \\
2.3 \\
4.7 \\
7.1 \\
8.9 \\
8.2\end{array}$ & $\begin{array}{l}-0.4 \\
+0.1 \\
+0.2 \\
-0.8 \\
-1.0 \\
+1.1 \\
-0.5 \\
-1.0 \\
+0.6 \\
+1.2 \\
+0.1 \\
-0.1\end{array}$ \\
\hline$\stackrel{m}{2}$ & & 18.8 & 5.6 & 12.2 & +0.4 & 41.1 & $\begin{array}{l}J u 1 \\
29+\end{array}$ & -18.3 & $\begin{array}{c}\text { Jan } \\
8\end{array}$ & 6.0 & +0.1 \\
\hline
\end{tabular}


SOLAR RADIATION AND WIND ACTIVITY
DURING THE 1971-73 STUDY $(6)$

\begin{tabular}{|c|c|c|c|c|c|c|c|c|c|c|c|}
\hline \multicolumn{6}{|c|}{ Solar Radiation (Langleys) } & \multicolumn{6}{|c|}{ Wind (kmph) } \\
\hline $\begin{array}{l}\text { 돔 } \\
\text { 올 }\end{array}$ & 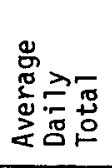 & 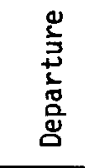 & 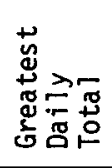 & 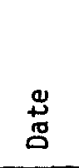 & 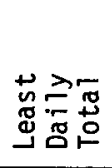 & $\underset{+}{ \pm}$ & 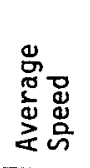 & 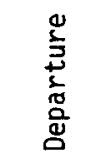 & 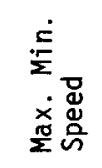 & 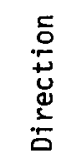 & 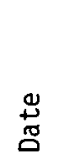 \\
\hline \multirow[t]{2}{*}{$\begin{array}{l}J \\
F \\
M \\
A \\
M \\
J \\
J \\
A \\
S \\
0 \\
N \\
D\end{array}$} & $\begin{array}{r}114 \\
211 \\
325 \\
488 \\
589 \\
619 \\
686 \\
602 \\
448 \\
286 \\
148 \\
96\end{array}$ & $\begin{array}{r}-4 \\
+11 \\
-15 \\
+18 \\
+18 \\
-7 \\
+27 \\
+51 \\
+30 \\
+24 \\
+13 \\
+5\end{array}$ & $\begin{array}{l}239 \\
329 \\
514 \\
681 \\
755 \\
821 \\
802 \\
703 \\
573 \\
430 \\
295 \\
185\end{array}$ & $\begin{array}{r}31 \\
28 \\
31 \\
26 \\
28 \\
14 \\
2 \\
3 \\
4 \\
1 \\
1 \\
7\end{array}$ & $\begin{array}{r}16 \\
54 \\
82 \\
153 \\
156 \\
220 \\
253 \\
242 \\
121 \\
58 \\
44 \\
37\end{array}$ & $\begin{array}{r}16 \\
9 \\
10 \\
24 \\
31 \\
3 \\
9 \\
22 \\
28 \\
30 \\
26 \\
2\end{array}$ & $\begin{array}{r}12.9 \\
13.8 \\
14.3 \\
13.5 \\
16.3 \\
13.5 \\
13.4 \\
12.6 \\
12.9 \\
11.6 \\
8.7 \\
10.9\end{array}$ & $\begin{array}{l}+2.7 \\
+2.6 \\
+0.8 \\
-1.0 \\
+2.1 \\
-1.3 \\
-0.5 \\
-0.3 \\
+0.8 \\
+0.8 \\
-1.3 \\
+1.3\end{array}$ & $\begin{array}{r}95 \\
105 \\
100 \\
80 \\
90 \\
63 \\
58 \\
60 \\
64 \\
66 \\
71 \\
72\end{array}$ & $\begin{array}{c}\text { WSW } \\
\text { SW } \\
\text { SSW } \\
\text { WSW } \\
\text { SSW } \\
\text { WSW } \\
\text { NW } \\
\text { SW } \\
\text { NNE } \\
\text { SSW } \\
\text { SW } \\
\text { SSW }\end{array}$ & $\begin{array}{c}9 \\
24 \\
26 \\
11 \\
12 \\
13 \\
4 \\
30 \\
19+ \\
19 \\
4 \\
13\end{array}$ \\
\hline & 385 & +171 & 821 & $\begin{array}{l}\text { Jun } \\
14\end{array}$ & 16 & $\begin{array}{l}\text { Jan } \\
16\end{array}$ & 12.9 & +0.4 & 105 & SW & $\begin{array}{l}\text { Feb } \\
24\end{array}$ \\
\hline \multirow[t]{2}{*}{$\begin{array}{l}J \\
F \\
M \\
A \\
M \\
J \\
J \\
A \\
S \\
0 \\
N \\
D\end{array}$} & $\begin{array}{l}134 \\
207 \\
343 \\
528 \\
595 \\
617 \\
654 \\
588 \\
428 \\
282 \\
103 \\
114\end{array}$ & $\begin{array}{r}+16 \\
+7 \\
+3 \\
+58 \\
+24 \\
-9 \\
-5 \\
+37 \\
+10 \\
+20 \\
-32 \\
+23\end{array}$ & $\begin{array}{l}249 \\
368 \\
536 \\
704 \\
752 \\
797 \\
796 \\
703 \\
565 \\
404 \\
233 \\
196\end{array}$ & $\begin{array}{l}29 \\
29 \\
29+ \\
28 \\
26 \\
18 \\
9 \\
1 \\
2+ \\
3 \\
5 \\
4\end{array}$ & $\begin{array}{r}50 \\
76 \\
47 \\
300 \\
158 \\
264 \\
118 \\
261 \\
136 \\
122 \\
38 \\
29\end{array}$ & $\begin{array}{r}20 \\
18 \\
1 \\
5 \\
21 \\
10 \\
8 \\
15 \\
21 \\
31 \\
30 \\
26\end{array}$ & $\begin{array}{r}16.6 \\
11.7 \\
12.1 \\
17.9 \\
13.5 \\
13.4 \\
13.8 \\
11.7 \\
12.4 \\
9.5 \\
6.8 \\
10.5\end{array}$ & $\begin{array}{c}+6.4 \\
+0.5 \\
-1.4 \\
+3.4 \\
-0.6 \\
-1.4 \\
0 \\
-1.1 \\
+0.3 \\
-1.3 \\
-3.2 \\
+0.8\end{array}$ & $\begin{array}{r}129 \\
103 \\
98 \\
117 \\
65 \\
74 \\
65 \\
58 \\
65 \\
55 \\
65 \\
71\end{array}$ & $\begin{array}{r}\text { SW } \\
\text { SW } \\
\text { SW } \\
\text { SSW } \\
\text { WNW } \\
\text { SW } \\
\text { SW } \\
\text { WNW } \\
\text { SSW } \\
N \\
\text { WNW } \\
\text { SW }\end{array}$ & $\begin{array}{r}11 \\
27 \\
5 \\
5 \\
31 \\
3 \\
12 \\
1 \\
19 \\
4 \\
26 \\
24\end{array}$ \\
\hline & 383 & +13 & 797 & $\begin{array}{l}\text { Jun } \\
18\end{array}$ & 29 & $\begin{array}{l}\text { Dec } \\
26\end{array}$ & 12.6 & -0.3 & 129 & SW & $\begin{array}{l}\text { Jan } \\
11\end{array}$ \\
\hline \multirow[t]{2}{*}{$\begin{array}{l}J \\
F \\
M \\
A \\
M \\
J \\
J \\
A \\
S \\
0 \\
N \\
D\end{array}$} & $\begin{array}{r}136 \\
208 \\
367 \\
535 \\
612 \\
644 \\
714 \\
588 \\
417 \\
255 \\
116 \\
86\end{array}$ & $\begin{array}{r}+18 \\
+8 \\
+27 \\
+65 \\
+41 \\
+18 \\
+55 \\
+37 \\
-1 \\
-7 \\
-19 \\
-5\end{array}$ & $\begin{array}{l}236 \\
341 \\
501 \\
681 \\
772 \\
788 \\
783 \\
689 \\
578 \\
434 \\
221 \\
173\end{array}$ & $\begin{array}{l}31+ \\
21 \\
23 \\
28 \\
31 \\
18 \\
1 \\
2 \\
1 \\
2 \\
17 \\
3\end{array}$ & $\begin{array}{r}52 \\
65 \\
157 \\
364 \\
219 \\
272 \\
543 \\
281 \\
92 \\
41 \\
31 \\
9\end{array}$ & $\begin{array}{r}20 \\
12 \\
12 \\
4 \\
24 \\
8 \\
20 \\
30 \\
22 \\
31 \\
11 \\
12\end{array}$ & $\begin{array}{r}10.1 \\
9.7 \\
13.2 \\
15.0 \\
15.1 \\
17.1 \\
14.6 \\
13.5 \\
11.4 \\
10.8 \\
12.1 \\
10.8\end{array}$ & $\begin{array}{r}0.0 \\
-2.6 \\
-0.3 \\
+0.5 \\
+1.0 \\
+2.2 \\
+0.8 \\
+0.6 \\
-0.6 \\
0.0 \\
+2.1 \\
+1.1\end{array}$ & $\begin{array}{l}60 \\
55 \\
68 \\
66 \\
69 \\
77 \\
63 \\
69 \\
61 \\
72 \\
82 \\
82\end{array}$ & $\begin{array}{r}\text { SW } \\
\text { SSW } \\
\text { WSW } \\
\text { SW } \\
\text { SW } \\
\text { WNW } \\
\text { WSW } \\
\text { WNW } \\
\text { WNW } \\
\text { SW } \\
\text { SW } \\
\text { SSW }\end{array}$ & $\begin{array}{c}24 \\
25 \\
10 \\
16 \\
8 \\
30+ \\
4 \\
4 \\
7 \\
6 \\
16 \\
11\end{array}$ \\
\hline & 390 & +20 & 788 & $\begin{array}{l}\text { Jun } \\
18\end{array}$ & 9 & $\begin{array}{l}\text { Dec } \\
12\end{array}$ & 12.7 & +0.5 & 82 & SSW & $\begin{array}{l}\text { Dec } \\
11+\end{array}$ \\
\hline
\end{tabular}




\section{APPENDIX C}

Geothermal Gradients at 32-49 Coordinates 


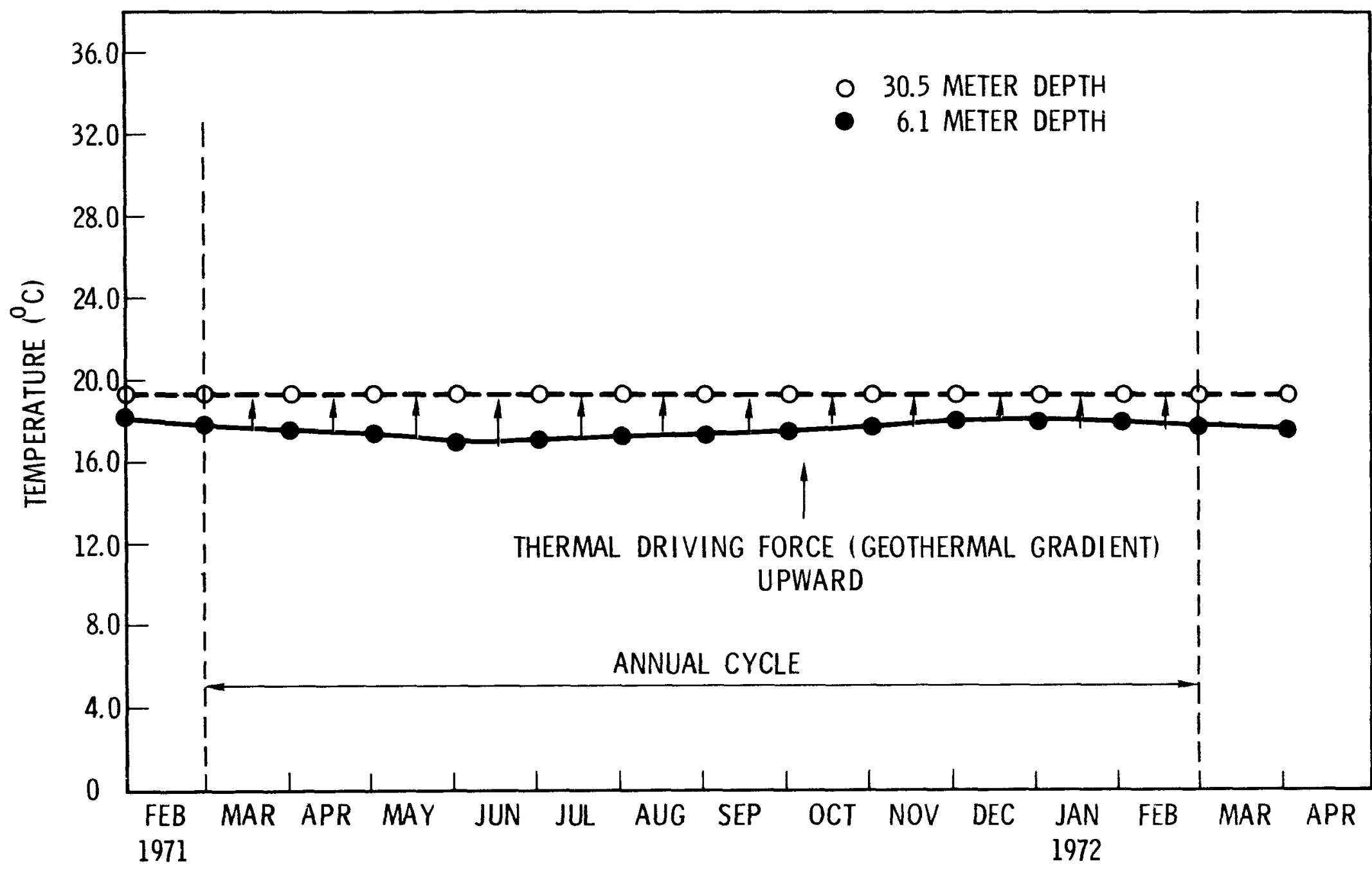

\section{FIGURE C -1}




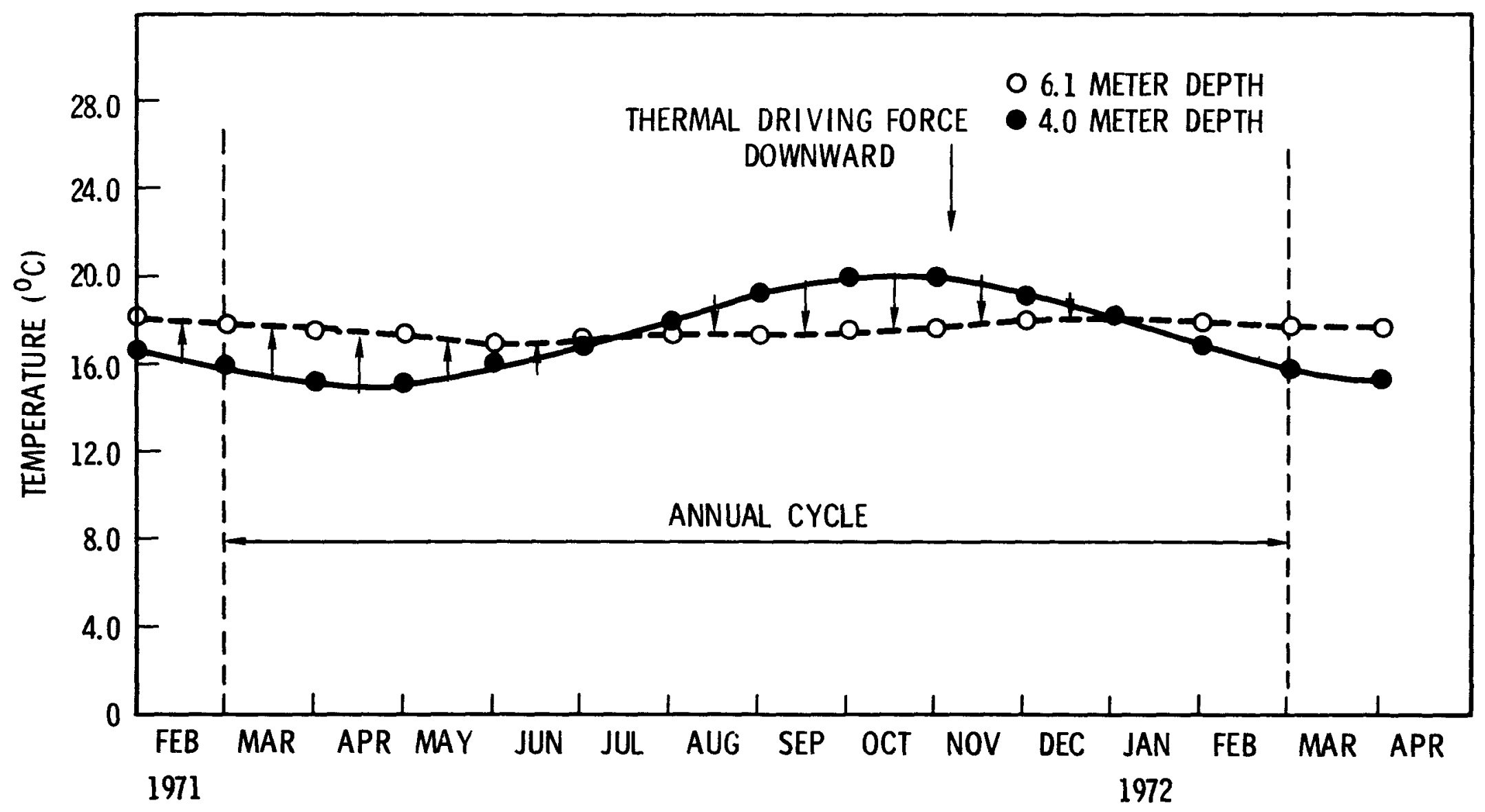

FIGURE $\quad$ C-2

ANNUAL CYCLIC THERMAL DRIVING FORCE AT 32-49 COORDINATES

BETWEEN 6.1 TO 4.0 DEPTHS 


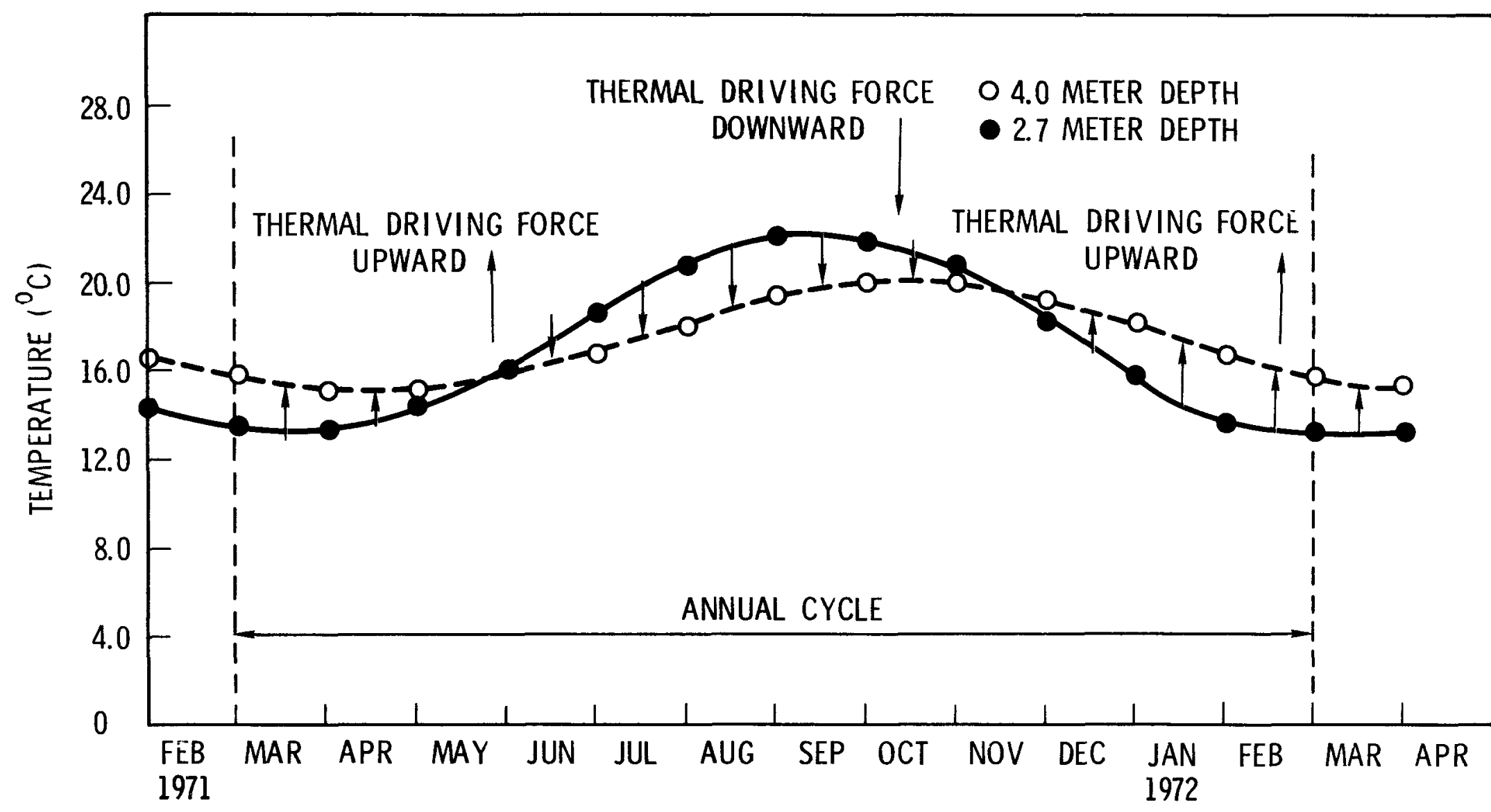

FIGURE $\quad C-3$

ANNUAL CYCLIC THERMAL DRIVING FORCE AT $32-49$ COORDINATES

BETWEEN 4.0 TO 2.7 METER DEPTH 


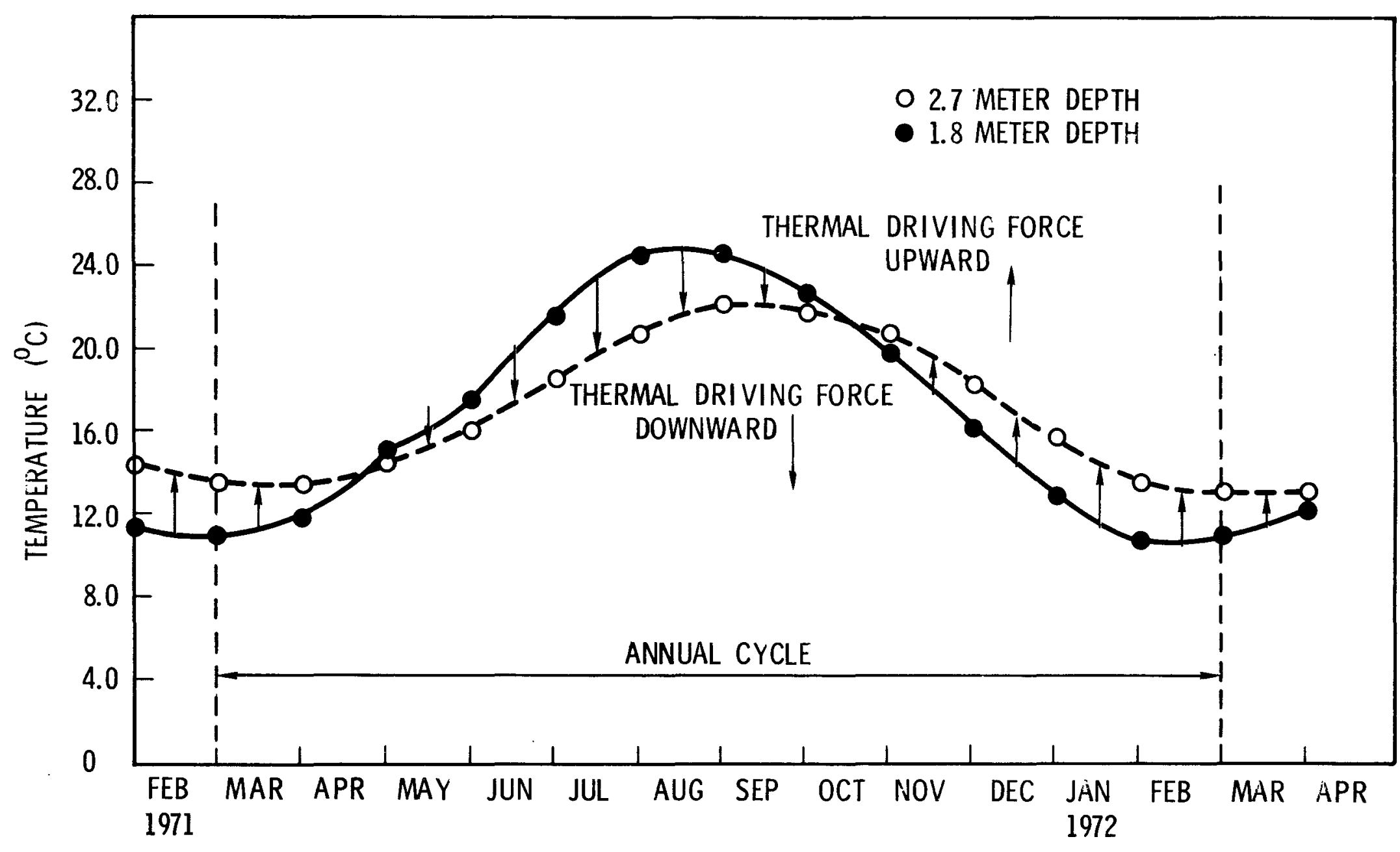

\section{FIGURE $\quad$ C-4}

ANNUAL CYCLIC THERMAL DRIVING FORCE AT 32-49 COORDINATES

BETWEEN 2.7 TO 1.8 METERS 


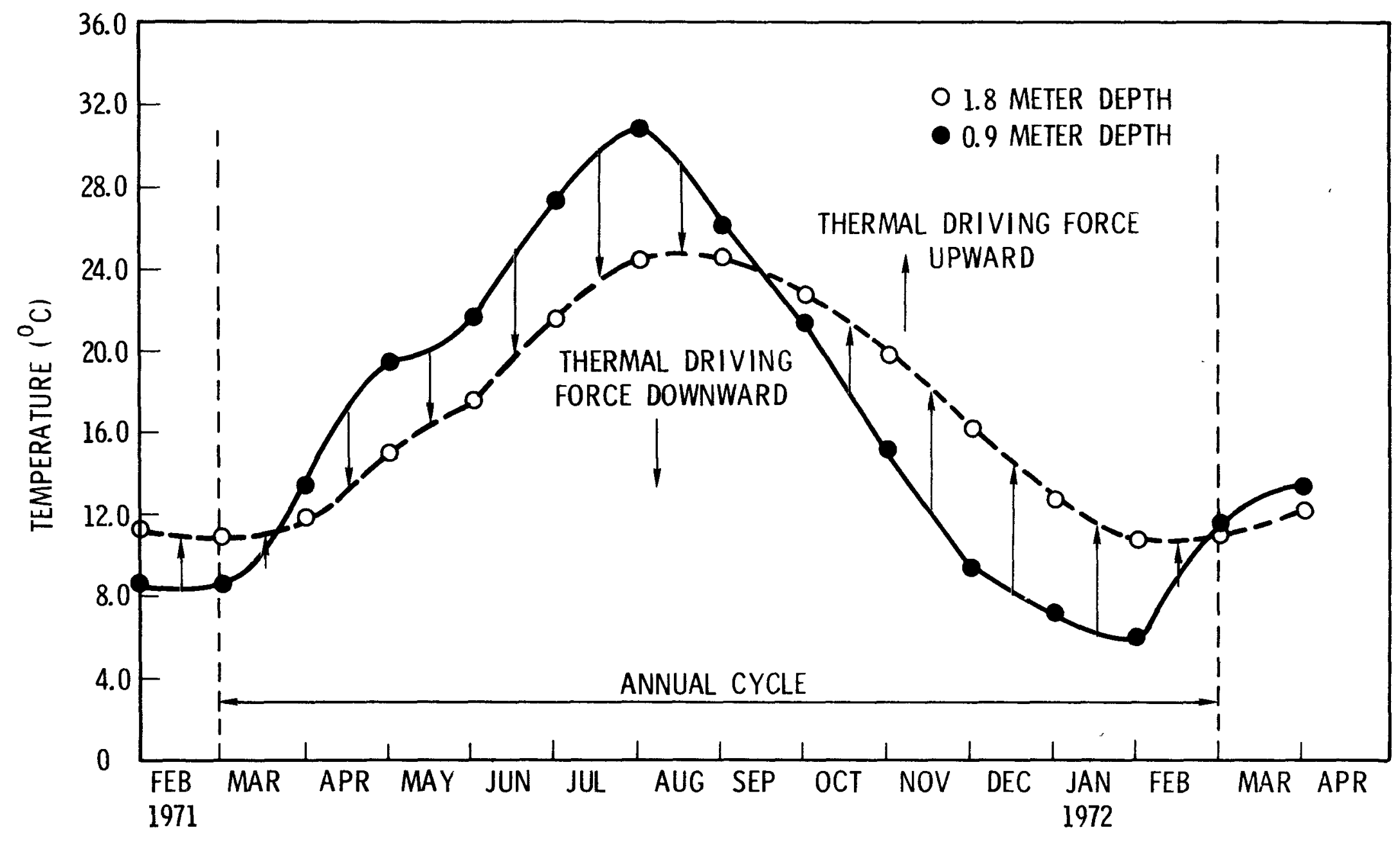

\section{FIGURE $\quad$ C-5}

ANNUAL CYCLIC THERMAL DRIVING FORCE AT 32-49 COORDINATE BETWEEN 1.8 TO 0.9 METER DEPTH 


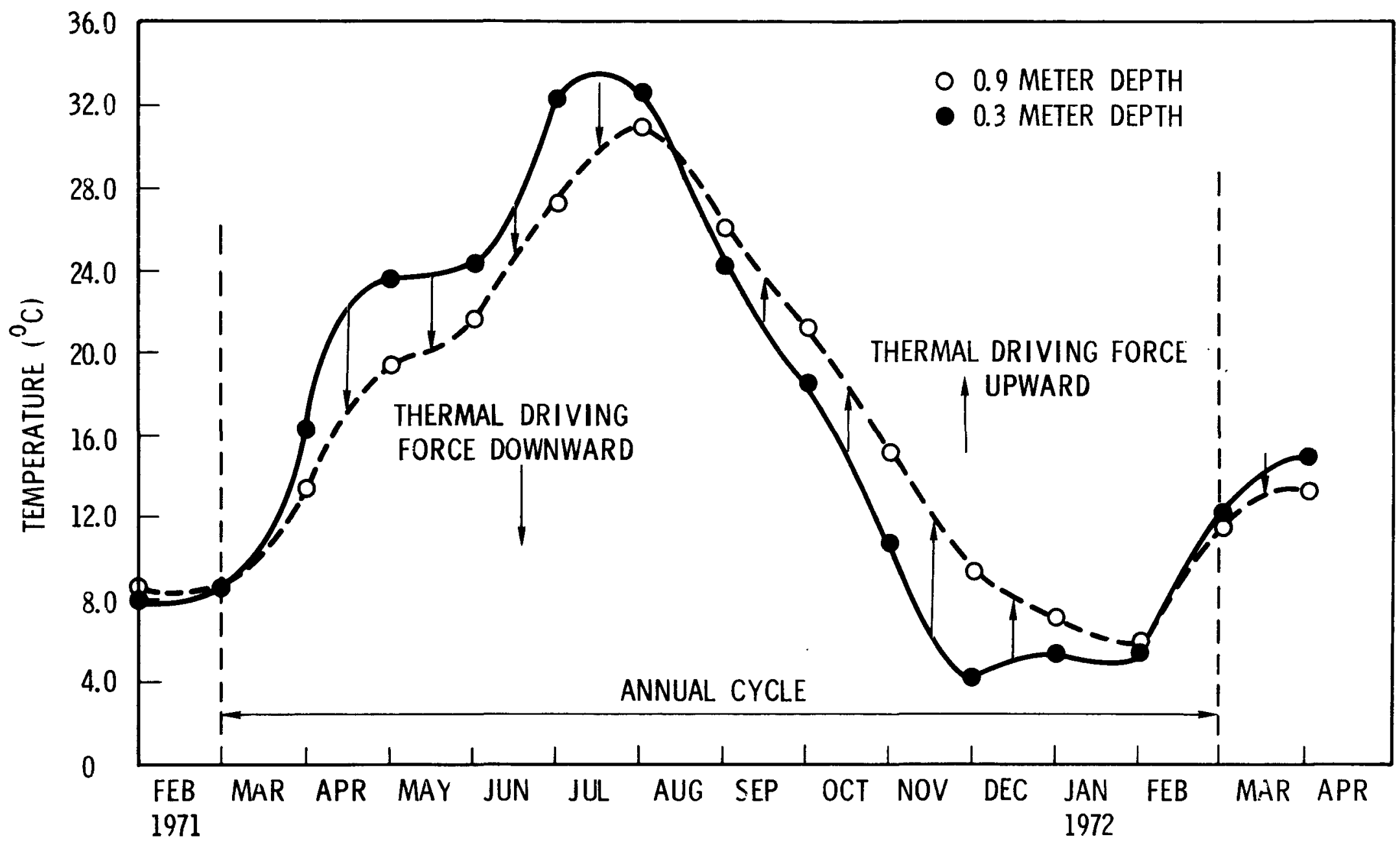

FIGURE C-6

ANNUAL CYCLIC THERMAL DRIVING FORCE AT 32-49 COORDINATES

BETWEEN 0.9 TO 0.3 METER DEPTHS 


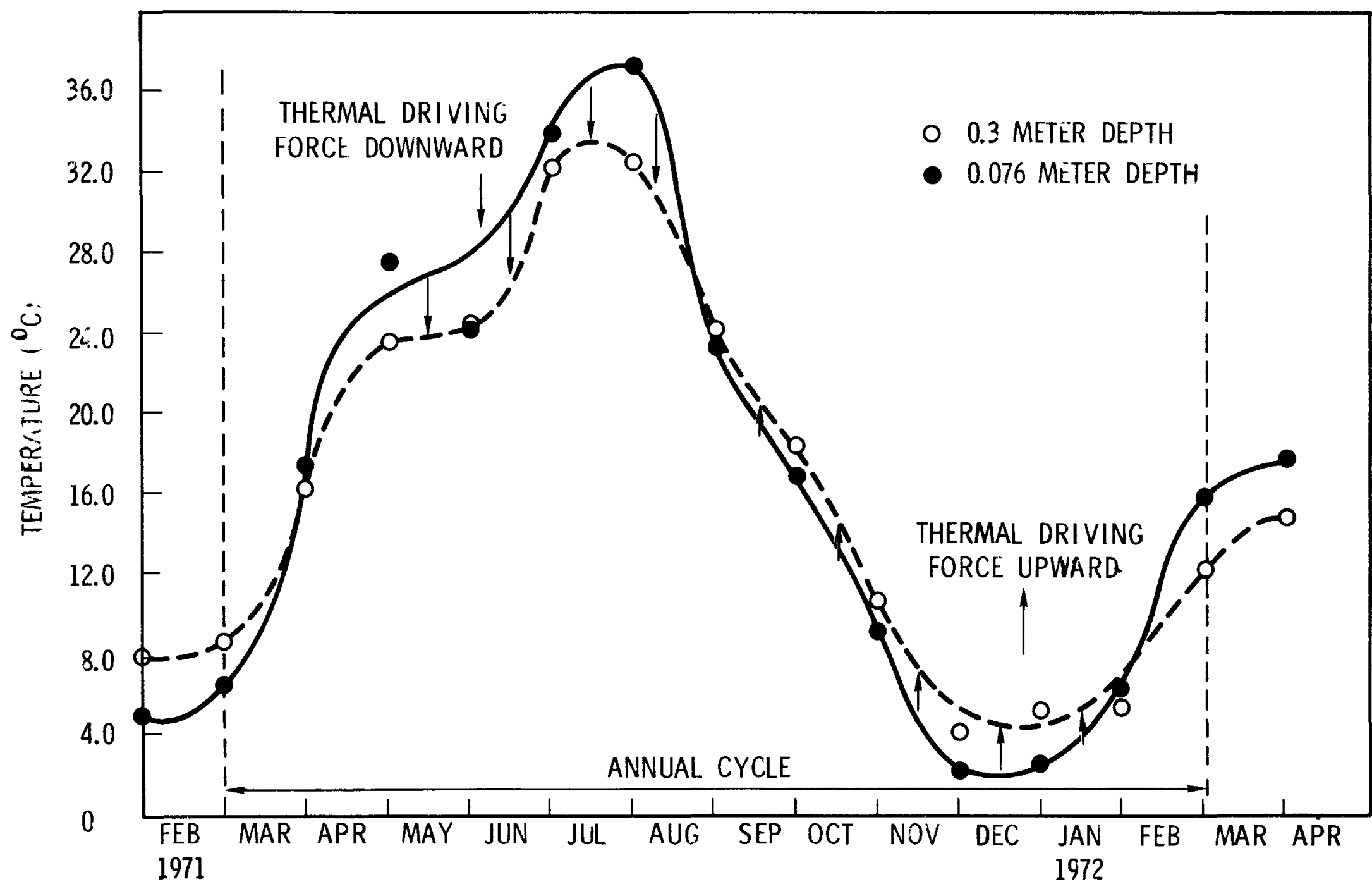

FIGURE $\quad$ C - 7

ANNUAL CYCLIC THERMAL DRIVING FORCE AT 32-49 COORDINATES

BETWEEN 0.3 TO 0.076 METER DEPTH 


\section{APPENDIX D}

\section{DIURNAL EFFECT}

As pointed out earlier in this report the soil temperature near the surface is highly influenced by daily variations of the climatic conditions in the atmosphere. During the daylight hours the surface soil temperature will increase steadily as heat is absorbed from the sun. During the night the surface of the earth radiates heat to outer space and loses heat to the atmosphere by radiation, convection and conduction. As a result heat is removed from the soil producing a steady reduction of the soil surface temperature at night (see figures $D-1$ and $D-2$ ). The magnitude of the daily variations in the soil temperature is greater during the summer months than during the winter months due to the greater heating effect of the sun during the summer. (38) The amplitudes of these daily temperature variations on the Hanford Reservation of a depth of $1.2 \mathrm{~cm}$ changes from approximately $5{ }^{\circ} \mathrm{C}$ in January to $30^{\circ} \mathrm{C}$ in July. At a depth of $38 \mathrm{~cm}$ the variation in the soil temperature due to the diurnal effect is negligible.

An equation, similar in form to the yearly sinusoidal equation, may be derived to predict the diurnal effect on soil temperature at the Hanford Reservation:

$$
T_{d}=A e^{-B} p^{d} \sin \left(B t_{n}+C\right)
$$

The term A, the amplitude, will be of a more complicated form than the amplitude of the yearly sinusoidal wave since it is a function of the time(month). The variations in the amplitude, although it does not follow an ideal sine curve, may be approximated by a sine function.

The term $B_{1}$ may be obtained from the calculations derived 
earlier in the report. Since:

$$
\begin{gathered}
\mathrm{B}_{1}=(\omega / 2 \mathrm{k}) 1 / 2[38] \text {, where } \mathrm{k}=0.004 \mathrm{~cm}^{2} / \mathrm{sec} \text { and } \\
\omega=\frac{2 \pi}{\text { i cycle } / 86400 \mathrm{secs}}=7.27 \times 10^{-5}
\end{gathered}
$$

The calculated value of $B_{1}$ is therefore $.095 \mathrm{~cm}^{-1}$. The term $B=15$ and the term C - 105 where the time in hours, $t_{n}$, is based on $t=0$ at midnight PST and each hour $t$ is incremented by 1 until 24 hours is reached. Therefore, the final equation predicting the diurnal effect on the soil temperature takes the form:

$$
T_{d}=\left[11 \sin \left(30 t_{m}-90\right) e^{-0.095 d n} \sin \left(15 t_{n}-105\right)\right.
$$

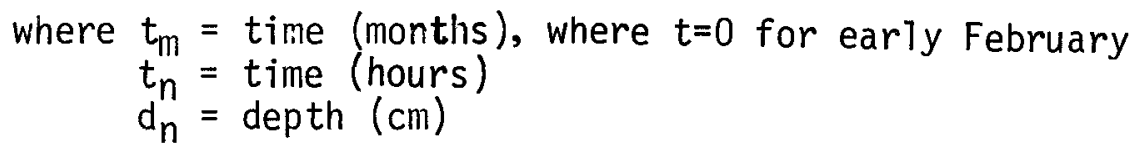

This equation may then be superimposed onto the yearly sinusoidal temperature equation to predict the hourly temperature of the soil as well as the seasonal temperature. The diurnal effect decreases to about $5 \%$ of its original magnitude at a depth of $31 \mathrm{~cm}$, thus becoming insignificant below this depth. Additional study may permit the development of more accurate equations to fit the data using Fourier series or similar techniques. 


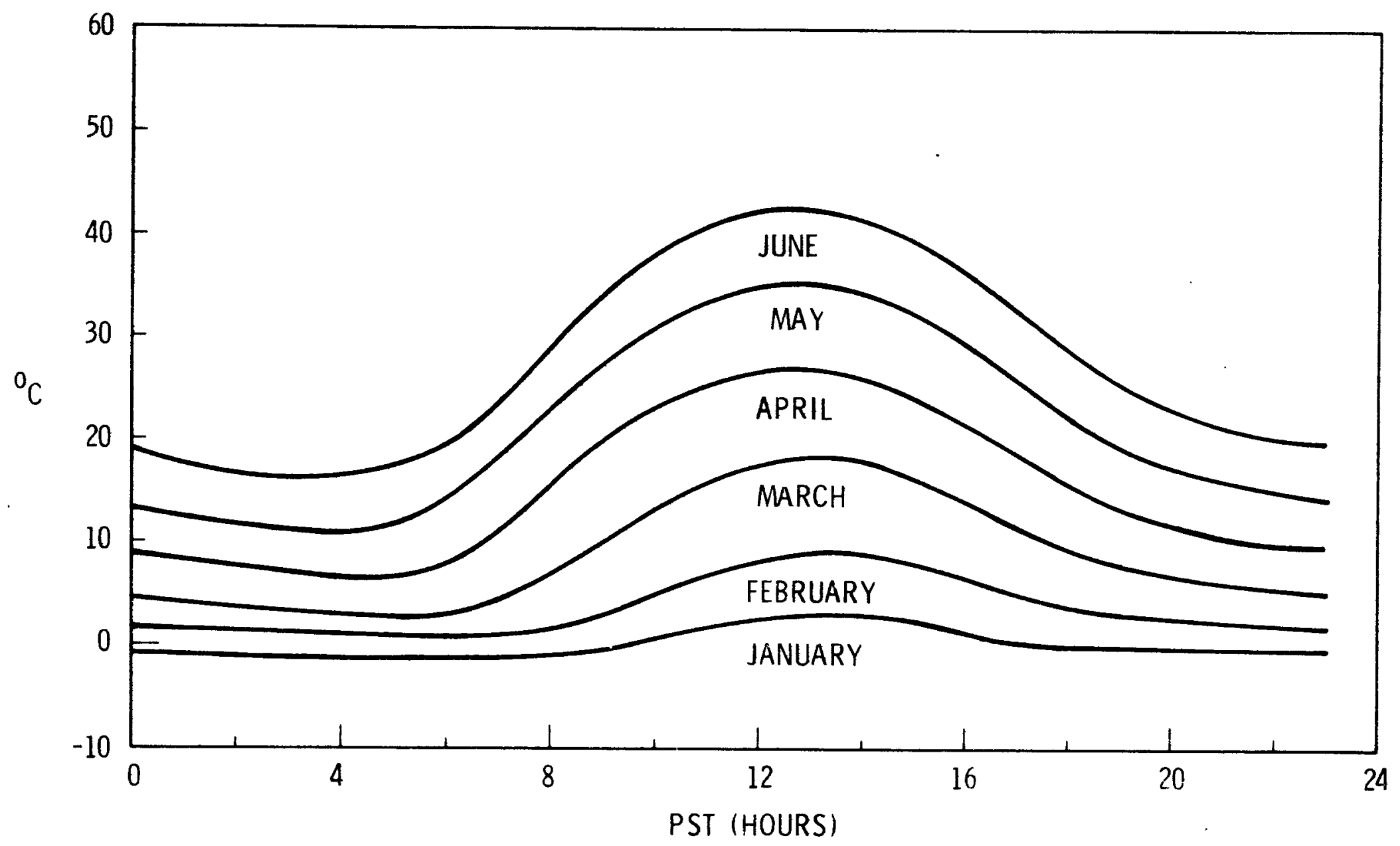

FIGURE D-1

AVERAGE HOURLY TEMPERATURES (1955-1970)

FOR THE FIRST SIX MONTHS OF YEAR 


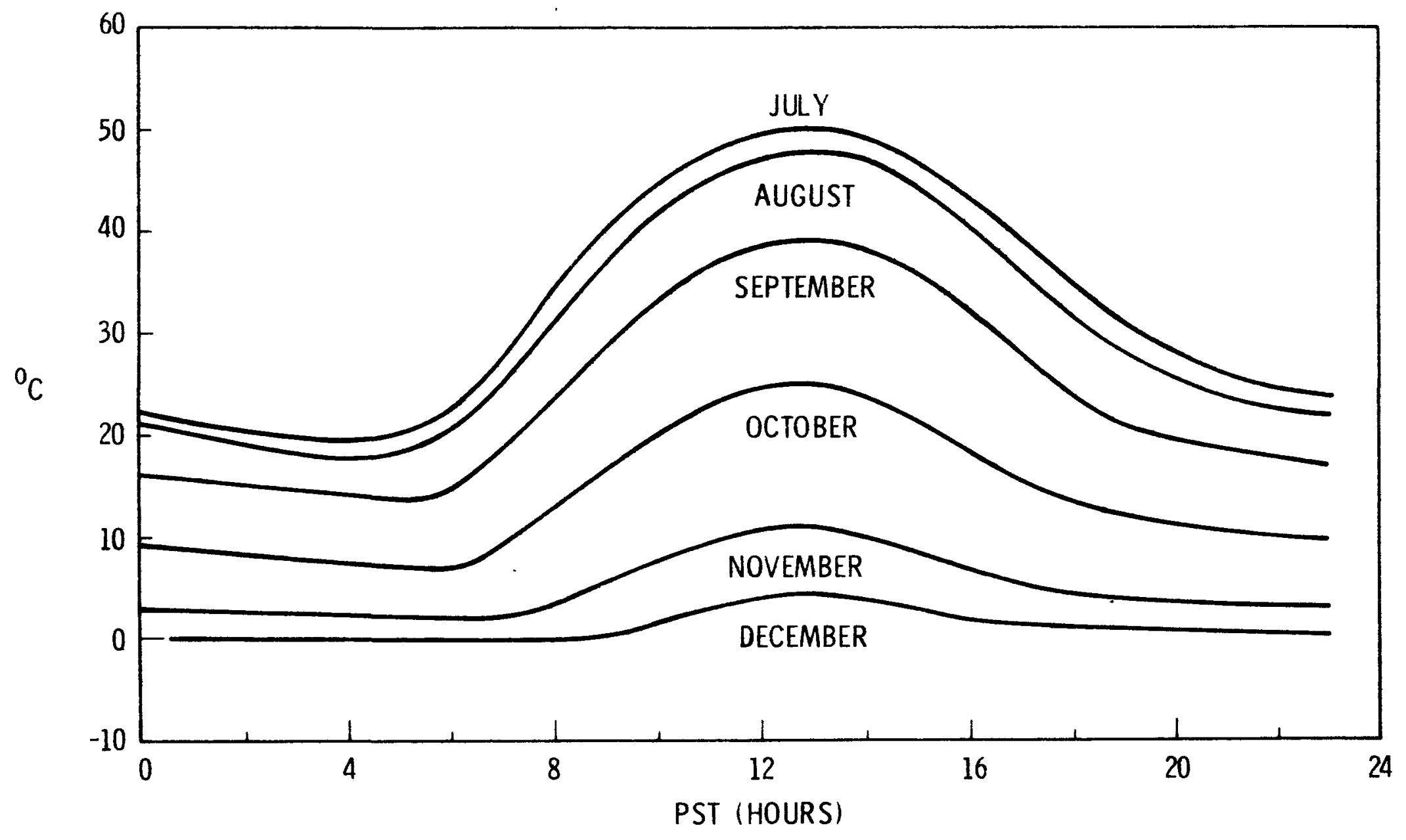

FIGURE D-2

AVERAGE HOURLY TEMPERATURES (1955-1970)

FOR LAST SIX MONTHS OF YEAR 


\section{APPENDIX E}

\section{NUMERICAL APPROACH FOR THE CALCULATIONS OF SOIL TEMPERATURES}

It is possible to predict soil temperatures as a function of depth and time based upon numerical techniques. This type of approach is desired when the surface soil temperatures fail to follow a sinusoidal pattern as is the case mentioned earlier. A possible method to do this is to use the Crank-Nicolson method. (39)

To use this method we start with the equation of Heat Transfer:

$$
\frac{\partial T}{\partial t}=k \frac{\partial^{2} T}{\partial x^{2}}
$$

The Crank-Nicholson technique uses the principle of finite differences to approximate the partial and second partial of temperature with respect to time and distance respectively.

First, a grid pattern is established letting the horizontal lines represent time and the vertical lines represent distance from the top of the surface as follows:

\begin{tabular}{|c|c|c|c|c|c|}
\hline & 1 & 2 & 3 & 4 & • \\
\hline 1 & $\mathrm{~T}_{1,1}$ & $T_{1,2}$ & $\mathrm{~T}_{1,3}$ & • & . \\
\hline & $T_{2,1}$ & $\mathrm{~T}_{2,2}$ & $\mathrm{~T}_{2,3}$ & • & • \\
\hline & $T_{3,1}$ & $T_{3,2}$ & $\mathrm{~T}_{3,3}$ & - & • \\
\hline & $T_{4,1}$ & $T_{4,2}$ & $T_{4,3}$ & • & $\bullet$ \\
\hline & • & • & - & • & • \\
\hline & • & • & • & . & • \\
\hline
\end{tabular}


$T_{1,1}$ represents the temperature at the surface at the original time; $T_{2,1}$ represents the temperature at a small finite distance below the surface at the original time, etc.

To use this method it is first necessary to know or approximate the values of $T_{i, 1}$ as $i$ varies from the surface depth to a depth, $n$, where $T$ is considered constant (approximately $30 \mathrm{~cm}$ for diurnal calculations and 7 meters for seasonal calculations). Also $T_{1,2}$, the new surface temperature, and $T_{n, 2}$ the lower limit temperature, is required.

As an example, assume that the second partial of $T$ with respect to distance is desired in order to obtain the new temperature at $T_{3,2}$. The Crank-Nicholson method begins by approximating $\partial^{2} \mathrm{~T} / \partial \mathrm{Z}^{2}$ as follows:

$$
\begin{aligned}
& \frac{\partial^{2} T}{\partial z^{2}}=\frac{\frac{T_{4,1}+T_{4,2}}{2}-\frac{T_{3,1}+T_{3,2}}{2}-\frac{T_{3,1}+T_{3,2}-\frac{T_{2,1}+T_{2,2}}{2}}{\Delta z}}{\Delta z} \\
& =\frac{1}{2(\Delta z)^{2}}\left(T_{4,1}+T_{4,2}+T_{2,1}+T_{2,2}-2 T_{3,1}-2 T_{3,2}\right)
\end{aligned}
$$

The first partial of $T$ with respect to time is approximated by :

$$
\frac{\partial T}{\partial t}=\frac{T_{3,2}-T_{3,1}}{\Delta t}
$$

Substituting equations 2 and 3 into 1 and rearranging gives:

$$
T_{3,2}=\frac{\Delta t_{k}}{2(\Delta z)^{2}} \frac{\left(T_{4,1}+T_{4,2}+T_{2,1}+T_{2,2}-2 T_{3,1}\right)+T_{3,1}}{1+\frac{k \Delta t}{(\Delta z)^{2}}}
$$


65

AR -2983

$$
\begin{aligned}
& \text { In general case we have: } \\
& T_{i j}=\frac{\Delta t_{k j}}{2(\Delta z)^{2}} \\
& \left(T_{i+1 ; j-1}+T_{i+1, j}+T_{i-1, j-1}+T_{i-1, j}-2 T_{i, j-1}\right)+T_{i, j-1} \\
& 1+\frac{k_{i} \Delta t}{(\Delta z)^{2}}
\end{aligned}
$$

where $k_{i}$ is in the thermal diffusivity at various depths. There will be an equation of the same format as (5). for each depth being considered except for the surface and the depth where $i=n$. At these two points the temperature is known.

These series of equations may be solved by using matrix algebra. We will start out by developing the following constants:

$$
\begin{aligned}
& N_{i}=\frac{\Delta t_{\kappa_{j}}}{(\Delta z)^{2}} \\
& c_{i}=T_{i+1, j-1}+T_{i-1, j-1}-2 T_{i, j-1} \\
& c_{i}=T_{i, j-1}
\end{aligned}
$$

Since the values of $T_{i, j}$ are being calculated for only one time period at a time, replace $T_{i, j}$ by $T_{i}$ ( $j$ is constant during one time period).

Equation 5 now becomes:

$$
\begin{aligned}
& T_{i}=\frac{\frac{1}{2} C_{1}\left(C_{i}+T_{i+1}+T_{i-1}\right)+C_{i}}{1+N_{i}} \\
& =\frac{\frac{1}{2} N_{i} C_{i}}{1+N_{i}}+\frac{1 N_{i} T_{i+1}}{1+N_{i}}+\frac{\frac{1}{2} N_{i} T_{i-1}}{1+N_{i}}+\frac{C_{i}}{1+N_{i}}
\end{aligned}
$$




$$
\text { Let } \begin{aligned}
Y_{i} & =\frac{\frac{1}{2} N_{i} C_{j}}{1+N_{i}}+\frac{C_{i 1}}{1+N_{i}} \\
a_{i} & =\frac{\frac{1}{2} N_{i}}{\frac{1+N}{1+N_{i}}}
\end{aligned}
$$

Substituting these values into (7) gives:

$$
T_{i}=Y_{i}+a_{i} T_{i+1}+a_{i} T_{i-1}
$$

Rearranging yields:

$$
-a_{i} T_{j-1}+T_{i} \quad-a_{j} T_{i+1}=Y_{i}
$$

There will be $n-2$ number of equations in the form as above with $n$ number of temperatures being considered. Putting these equations in matrix form will give:

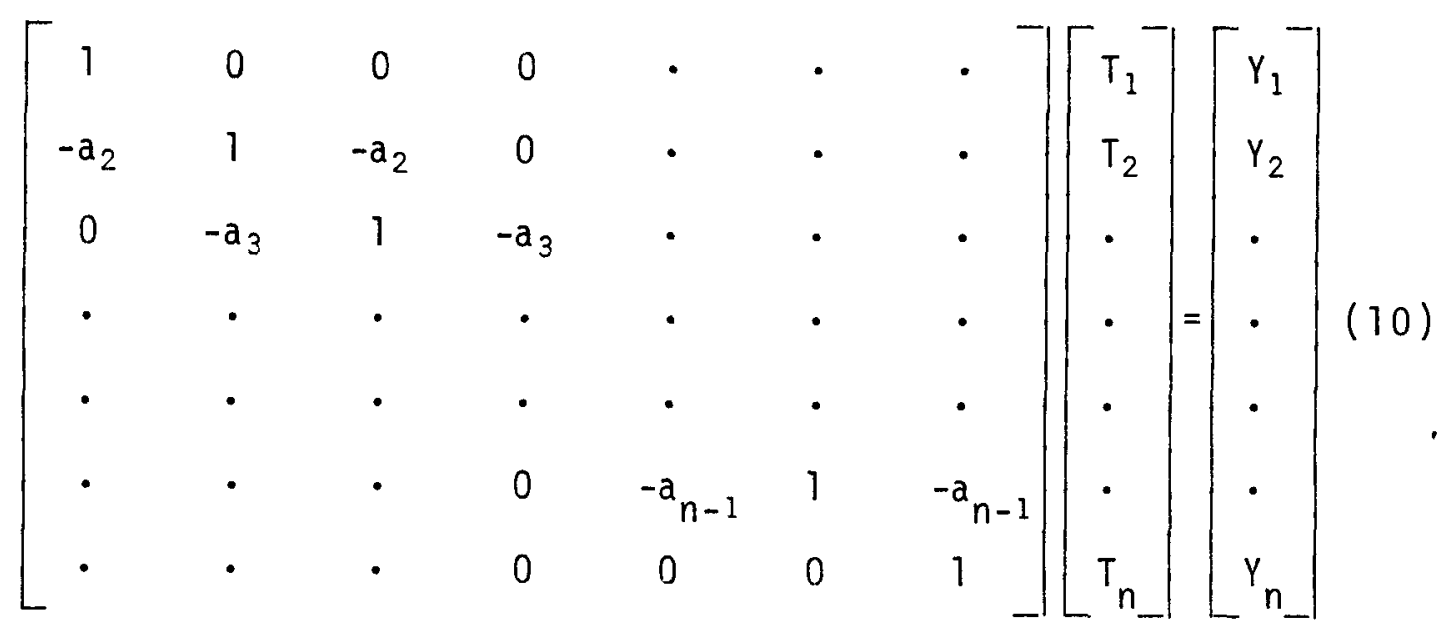

This equation may be represented in the following form:

$$
A T=Y
$$


To solve for the values of $T$ it is first necessary to obtain an inverse matrix of $A$, represented by $A^{-1}$. AT and $Y$ are then multiplied by $A^{-1}$ yielding:

$$
T=A^{-1} Y
$$

In this way it is possible to obtain the new temperature profile and to use these new values of temperatures to calculate the temperatures at a time $\Delta t$ from the time of the last calculation.

It is possible to vary the value of $k$, the thermal diffusivity, for various depths if the effect of soil stratification is significant. If the soil stratification is not considered significant then $\kappa$ can be assumed a constant. This will simplify the matrix operations, also, assuming $\Delta t$ and $\Delta z$ are constant, since all values of $a_{j}$ will be the same. 
This page is intentionally blank 
CONTAMINATION OF SOIL WATER DURING SAMPLING

In the initial sampling of soil samples from the drilling of dry wells on the Hanford plateau, the soil was recovered from the drill pipe and stored in plastic tags in the field. Data for these samples on the tritium analyses in tritium units versus the weight percent moisture in the sample are plotted in the right side of Figure F-l. The low moisture content samples approximately 1.0 wt\% had tritium contents of 60 to $80 \mathrm{TU}$; tritium counts were lower in soils containing greater moisture. These data were interpreted as indicative of contamination during sampling. For example, a soil with $2.8 \mathrm{wt} \%$ had a moisture tritium content of 11 TU as compared to $88 \mathrm{TU}$ for samples with only about $1.0 \mathrm{wt} \%$ moisture.

The use of glass containers rather than plastic bags, the removal of absorbed water by washing with acetone, use of surgeon's gloves in handling the samples, and flushing the containers with dry argon reduced contamination by a factor of about ten. If this is indeed the case, the contamination in terms of the tritium content would continue to be influenced by the amount of moisture in the soil samples. The dashed line to the left of Figure F-l shows the relationships of tritium contamination to absolute moisture. This indicates that even with improved procedures some finite contamination is involved, possibly ranging from 2 to 8 TU for soil samples with moisture contents from 2.4 to 1.0 wt\% water. 


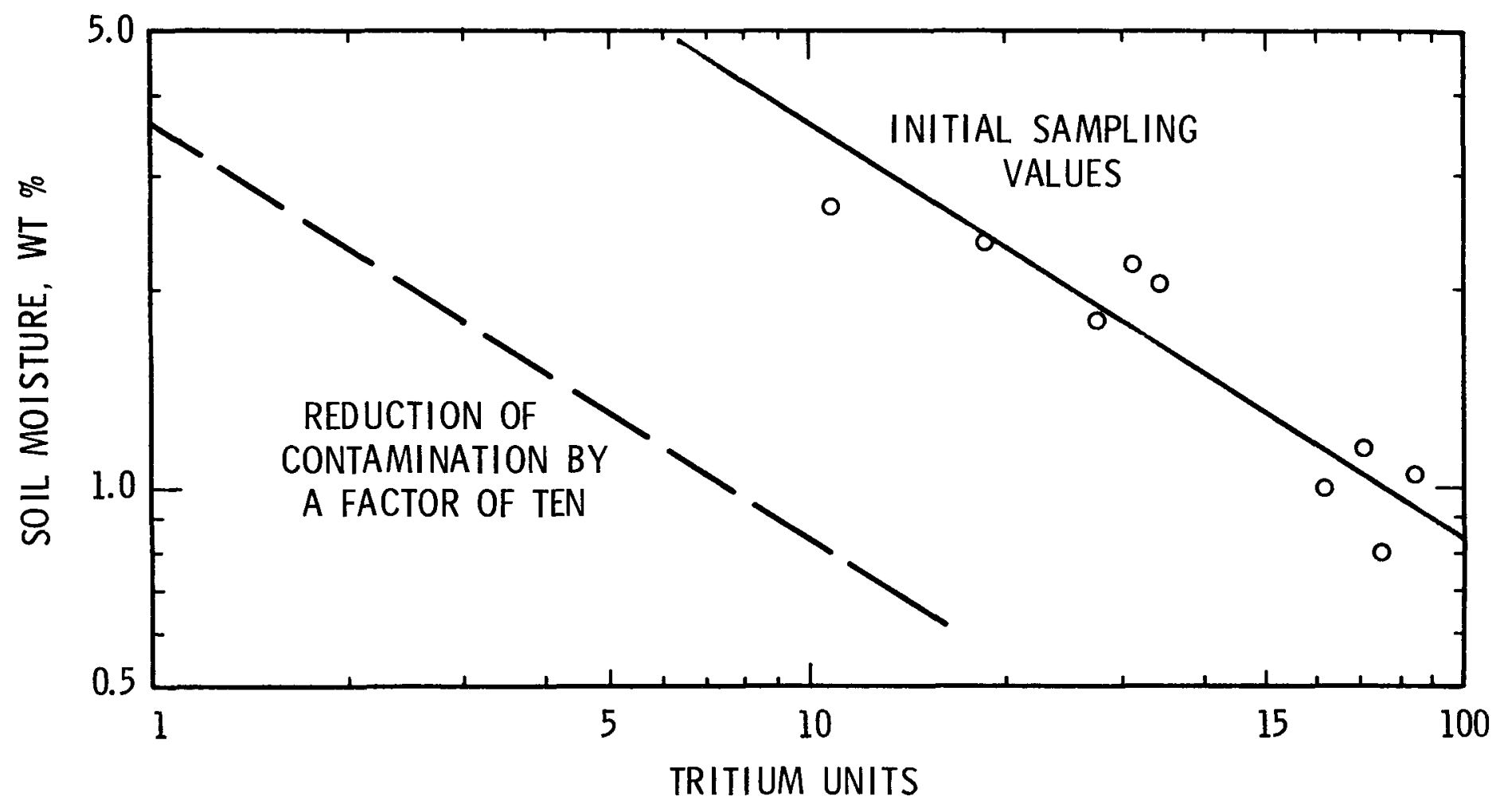

ò

FIGURE $F-1$

TRITIUM ANALYSES OF SOIL MOIASTURE IN SOIL SAMPLES

FROM WELL $12-48$ 


\section{FIGURES}




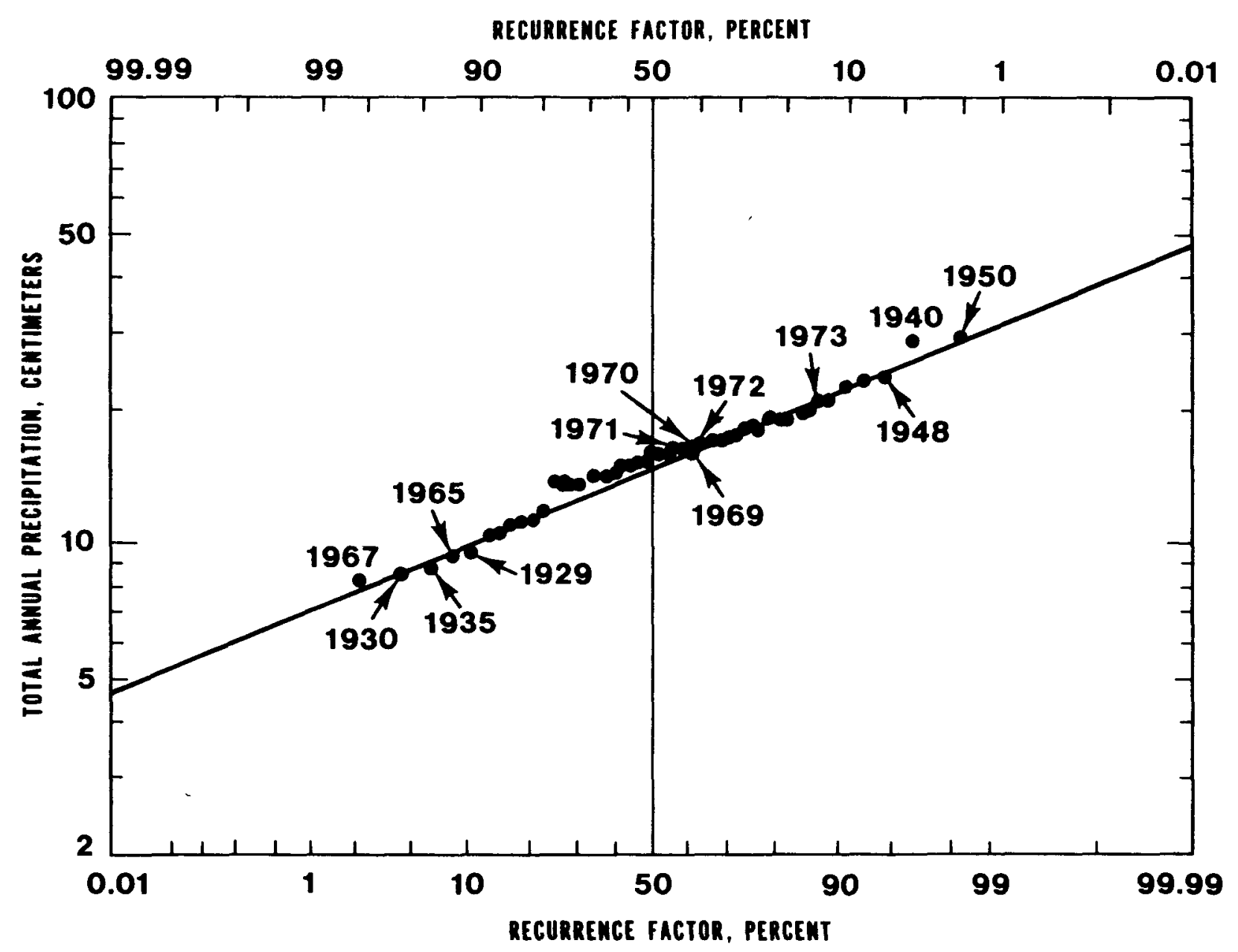

FIGURE 1

TOTAL ANNUAL PRECIPITATION (1913-1973) FOR THE 200 AREA PLATEAU

AT HANFORD RESERVATION

[AFTER JENNE (6) ] 


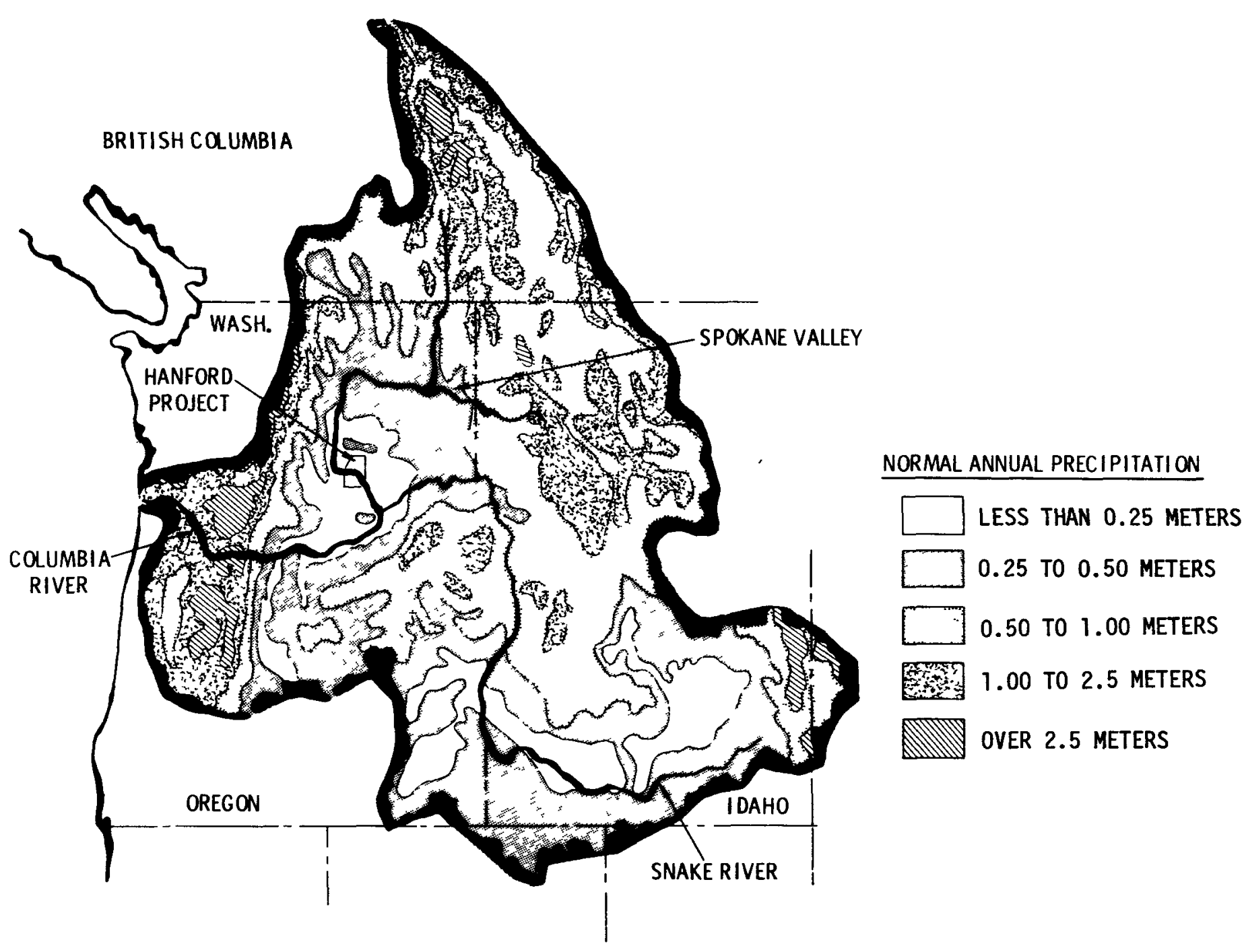

\section{FIGURE 2}

ANNUAL PRECIPITATION WITHIN THE COLUMBIA RIVER DRAINAGE BASIN [AFTER U. S. ARMY CORPS OF ENGINEERS $(7)$ ] 


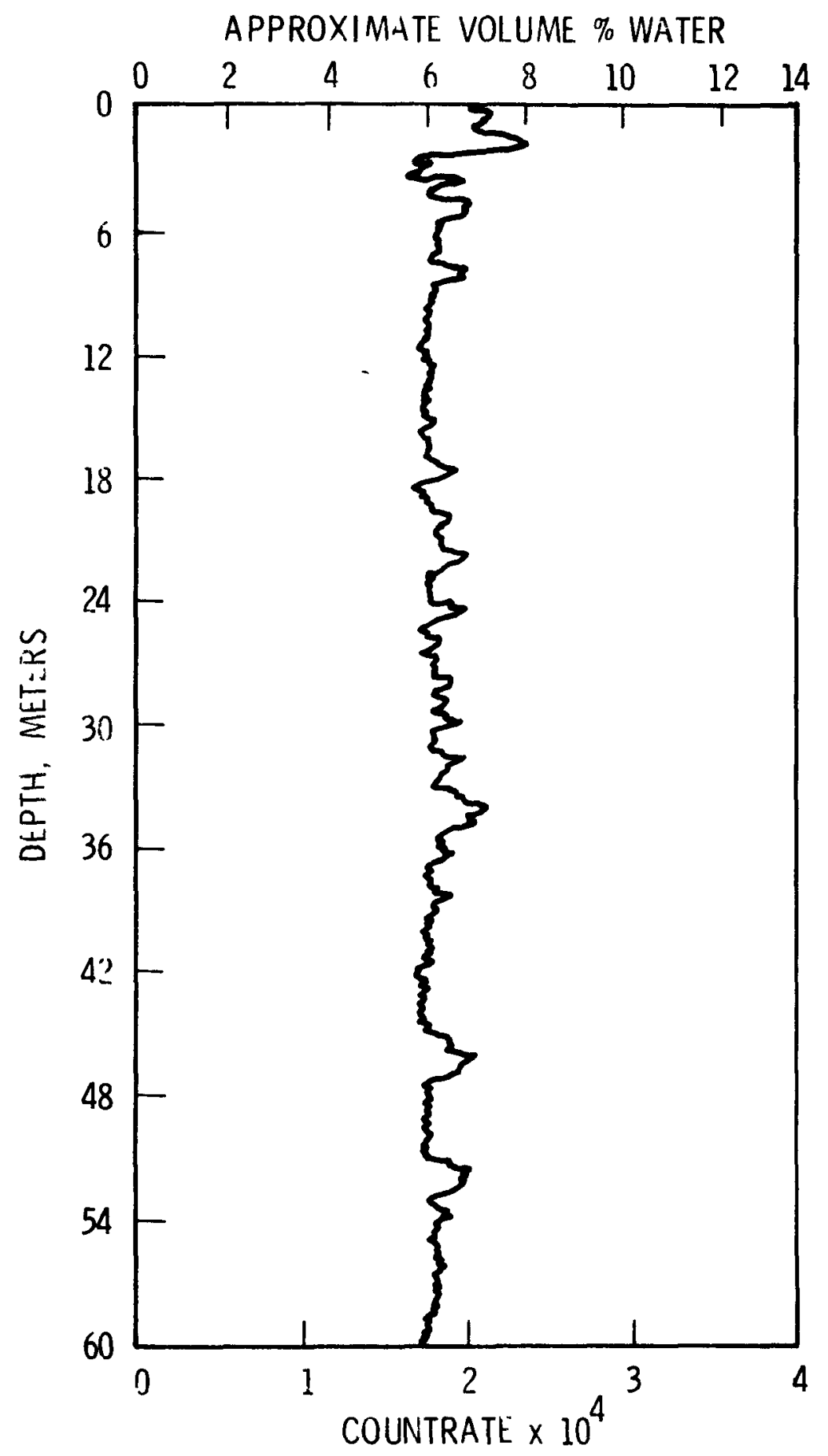

FIGURE 3

NEUTRON LOG OF WELL $2 A(32-49 A)$ 


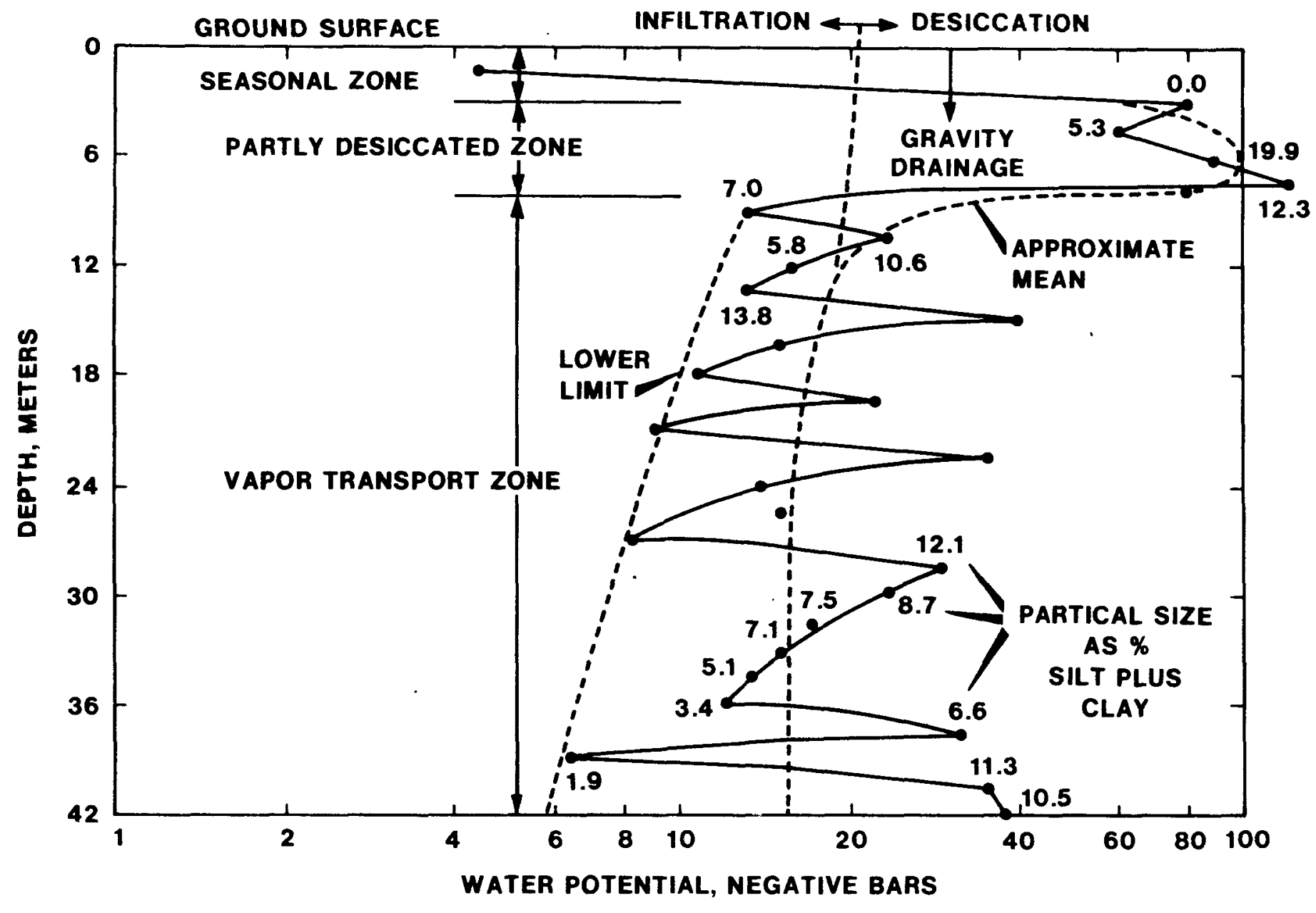

$\underline{\text { F I GURE } 4}$

WATER POTENTIAL VERSUS DEPTH FOR WELL $2 A$ (32-49A) 


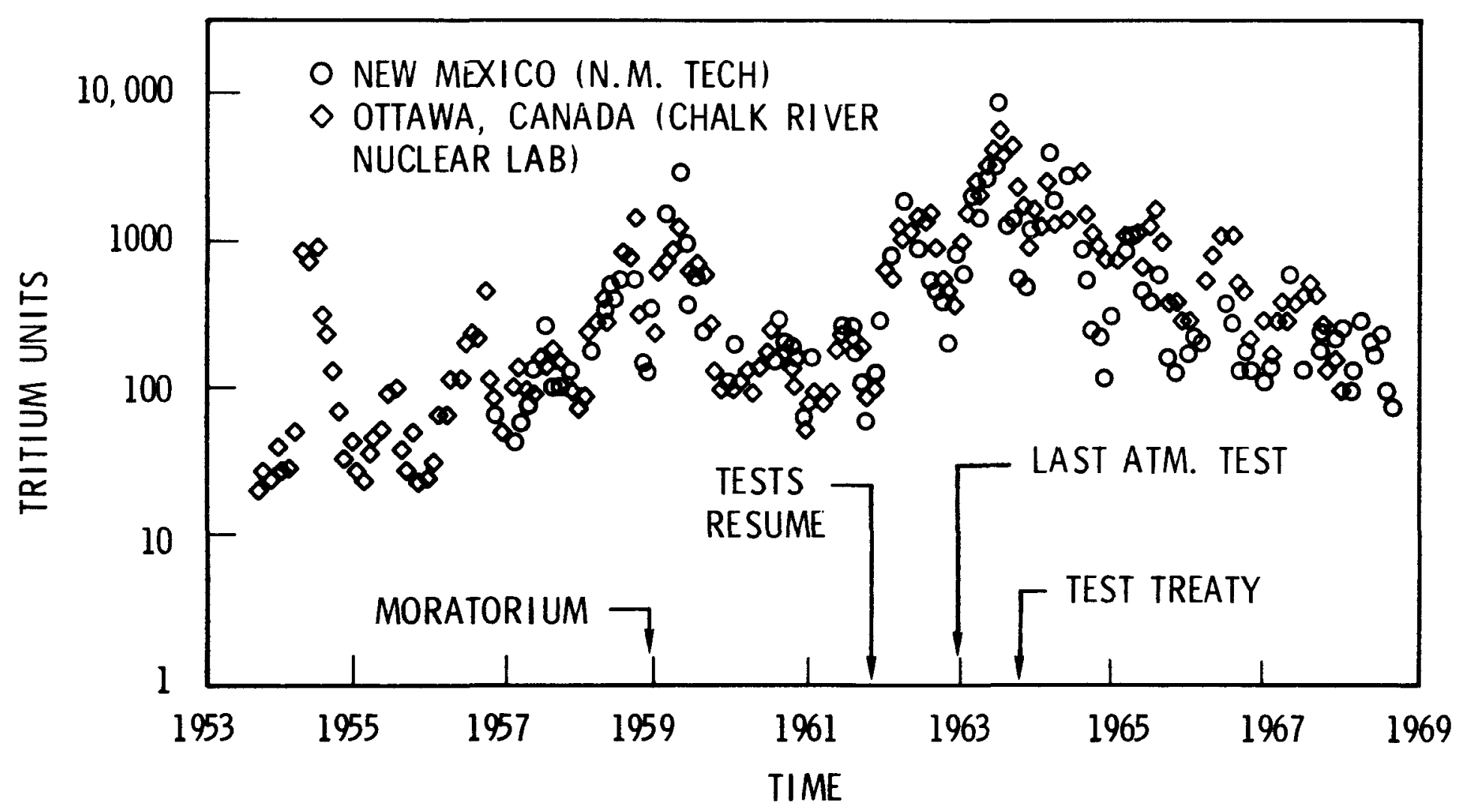

FIGURE 5

MEAN MONTHLY TRITIUM CONCENTRATION

OTTAWA, CANADA AND CENTRAL NEW MEXICO 


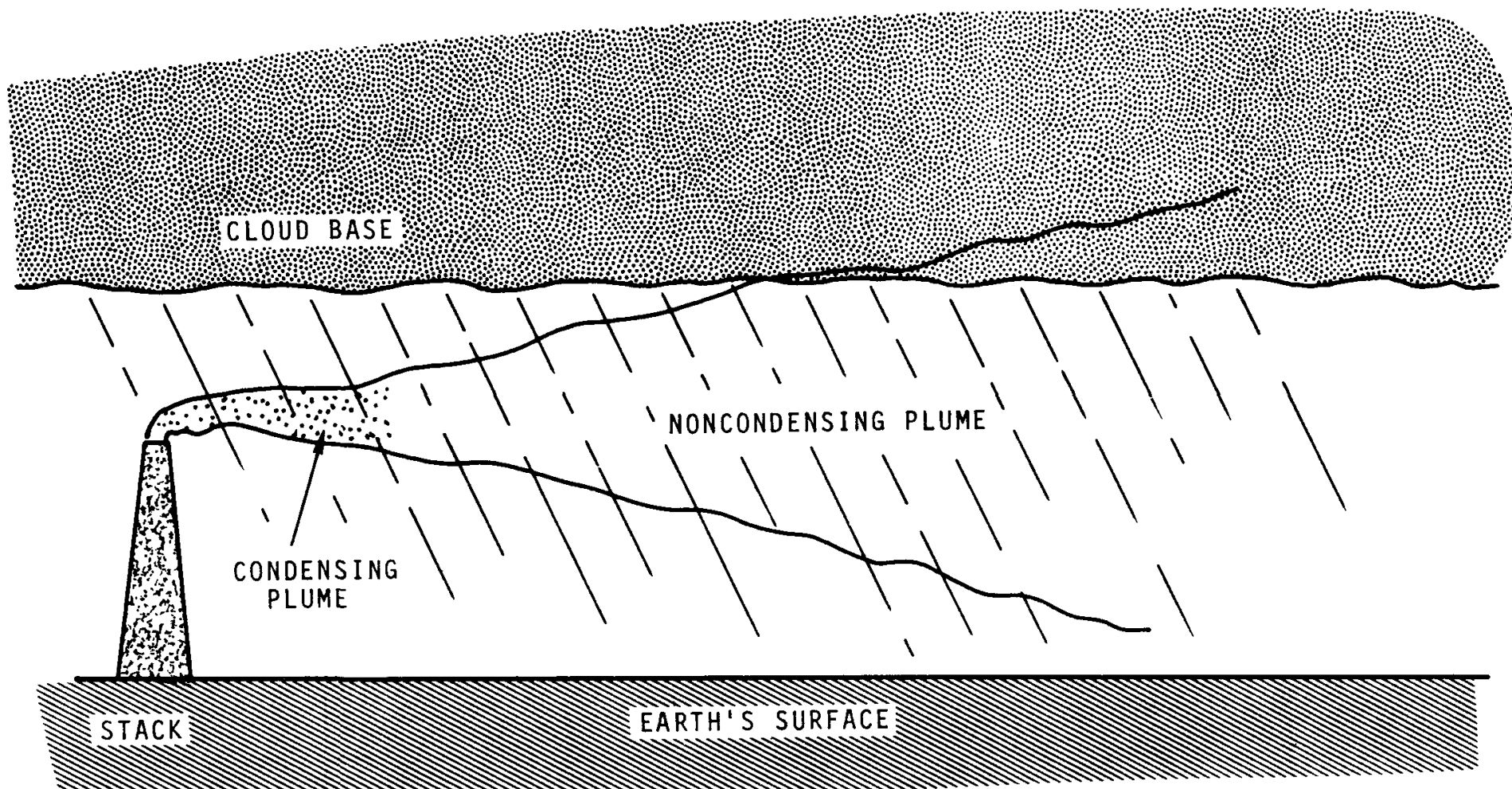

\section{FIGURE 6}

SCHEMATIC OF PRECIPITATION-PLUME INTERACTION

ON HANFORD SITE 


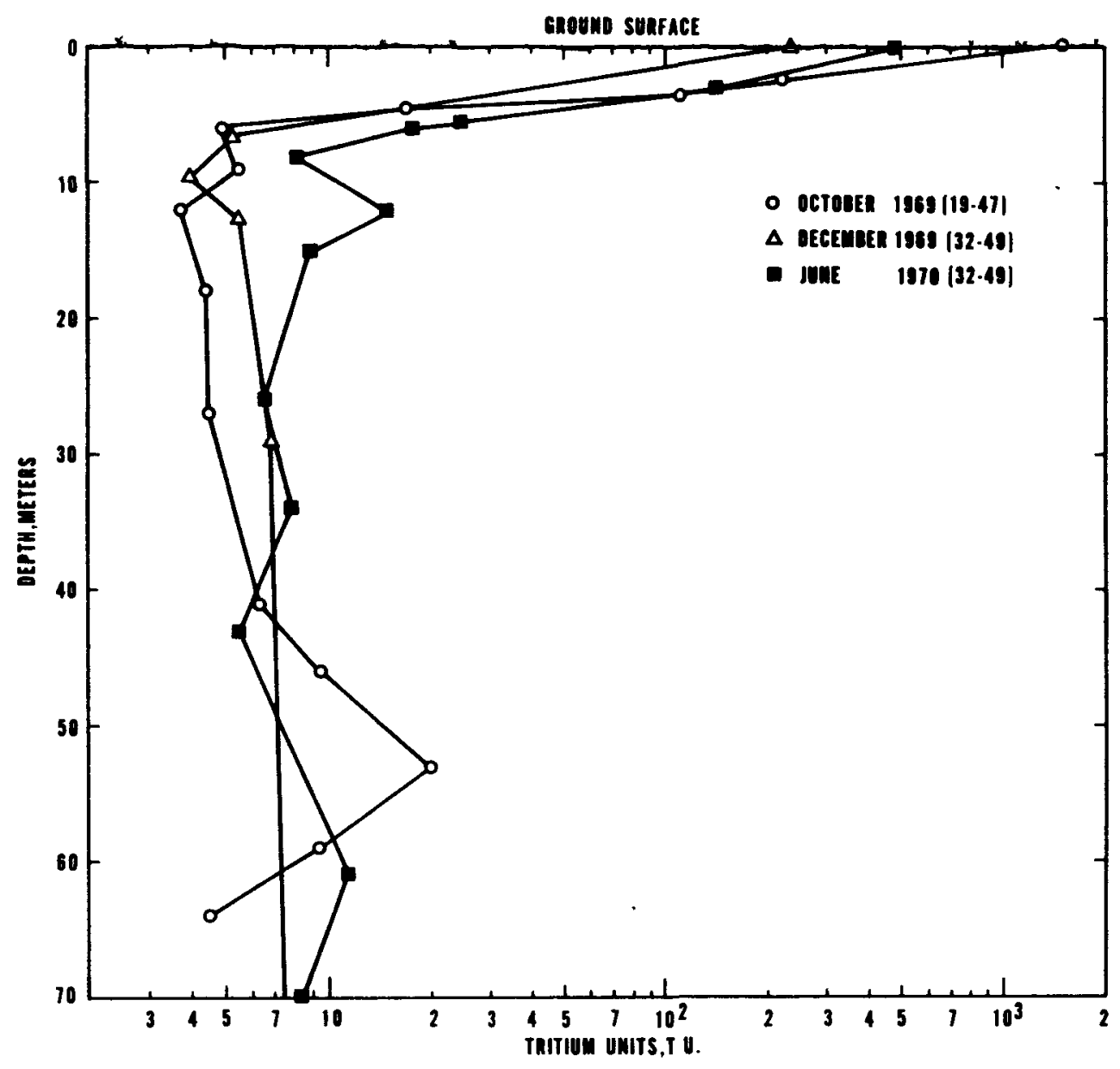

FIGURE 7 


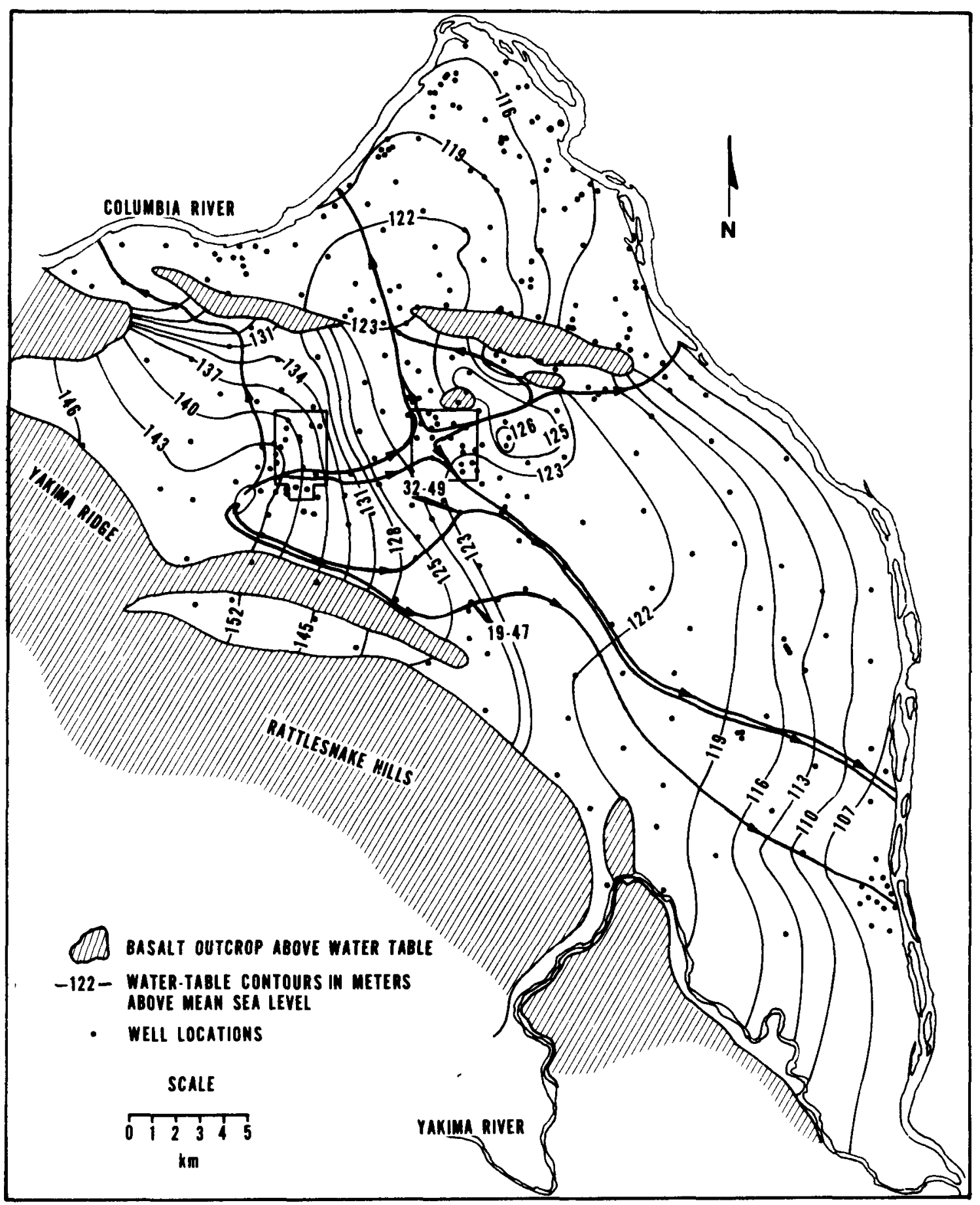

FIGURE 8

GROUNDWATER ELEVATIONS AND FLOW PATHS ON HANFORD RESERVATION 

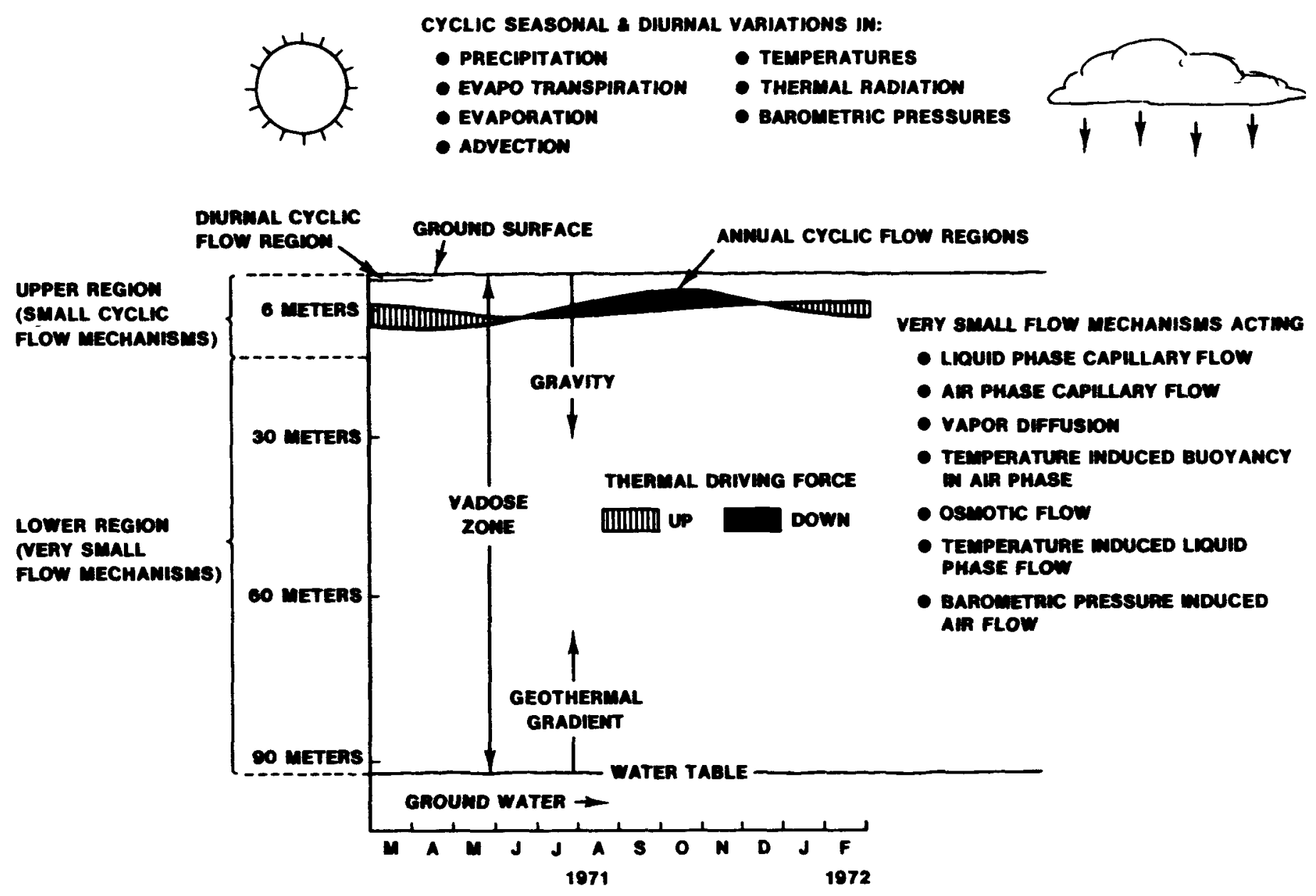

\section{FIGURE 9}

TRANSPORT MECHANISMS BASIC TO MOISTURE REDISTRIBUTION

IN SEMI-ARID VADOSE ZONES 


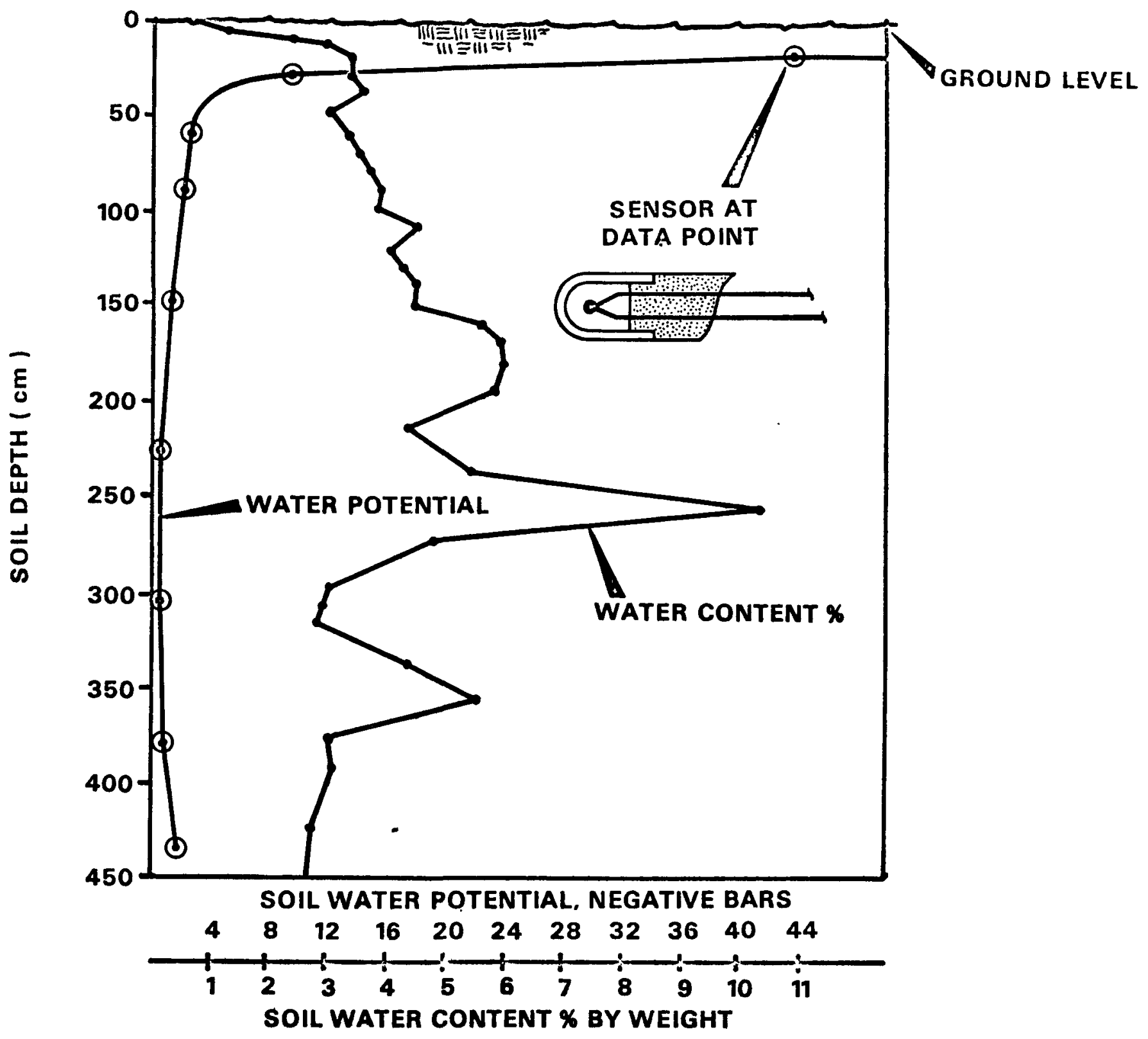

\section{FIGURE 10}

WEIGHT PERCENT SOIL MOISTURE AND AVERAGE WATER POTENTIAL PROFILES 


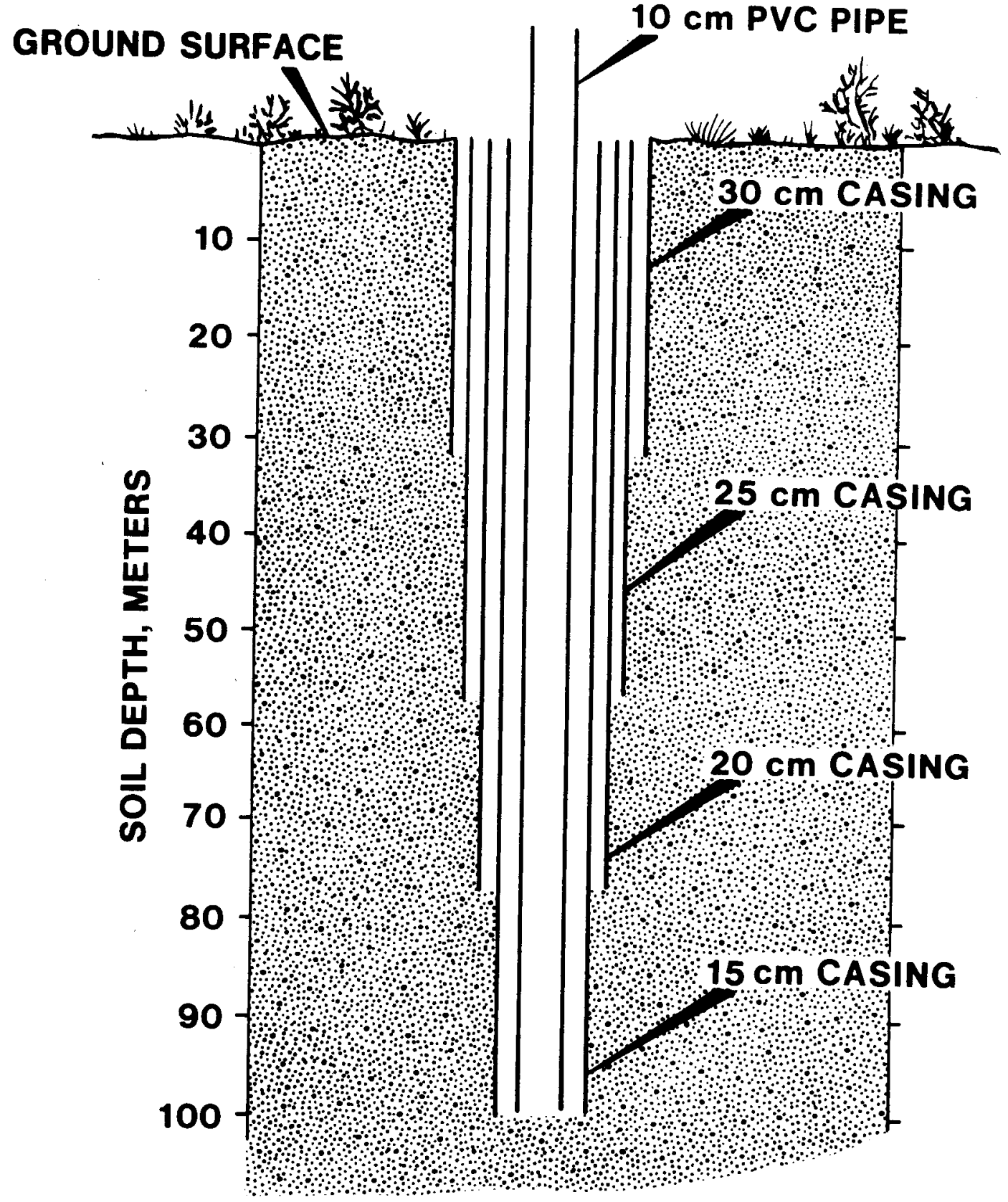

FIGURE 11

CONCENTRIC CASING METHOD USED

AT WELL 32-49D 


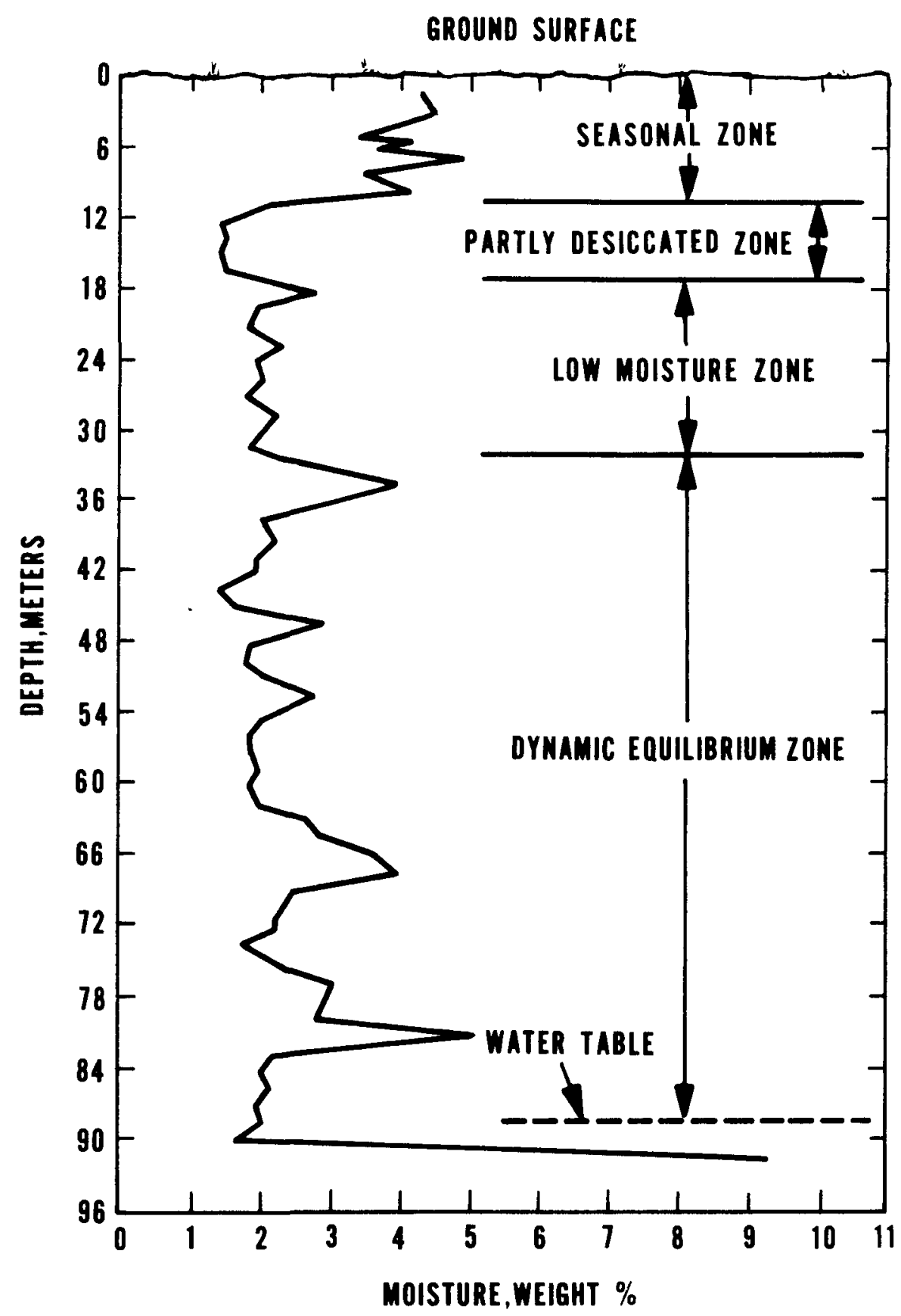

FIGURE 12

SOIL MOISTURE PROFILES

IN WELL 32-49D 


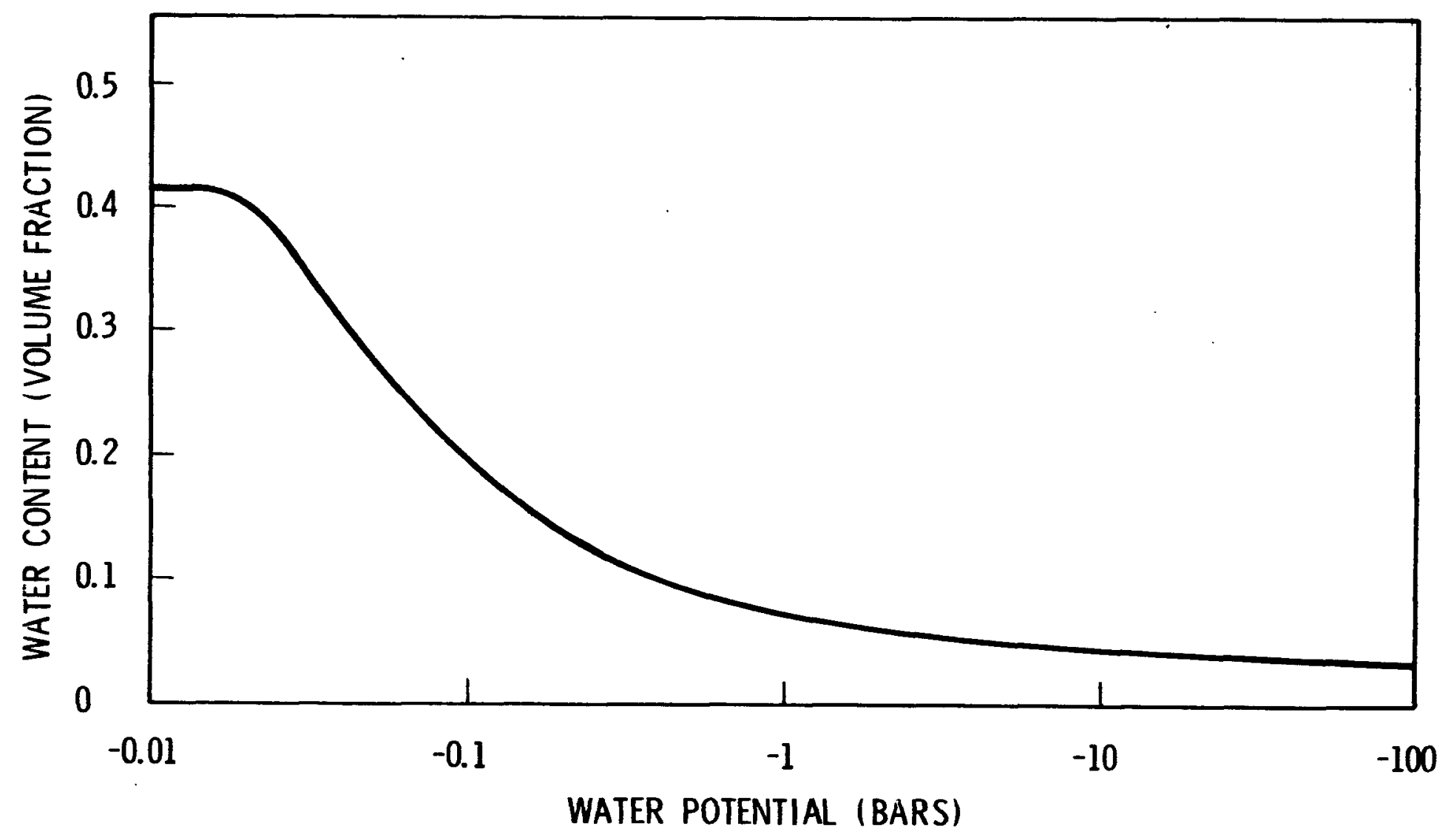

FIGURE 13

WATER POTENTIAL AS A FUNCTION OF MOISTURE CONTENT

FROM WELL 32-49D 


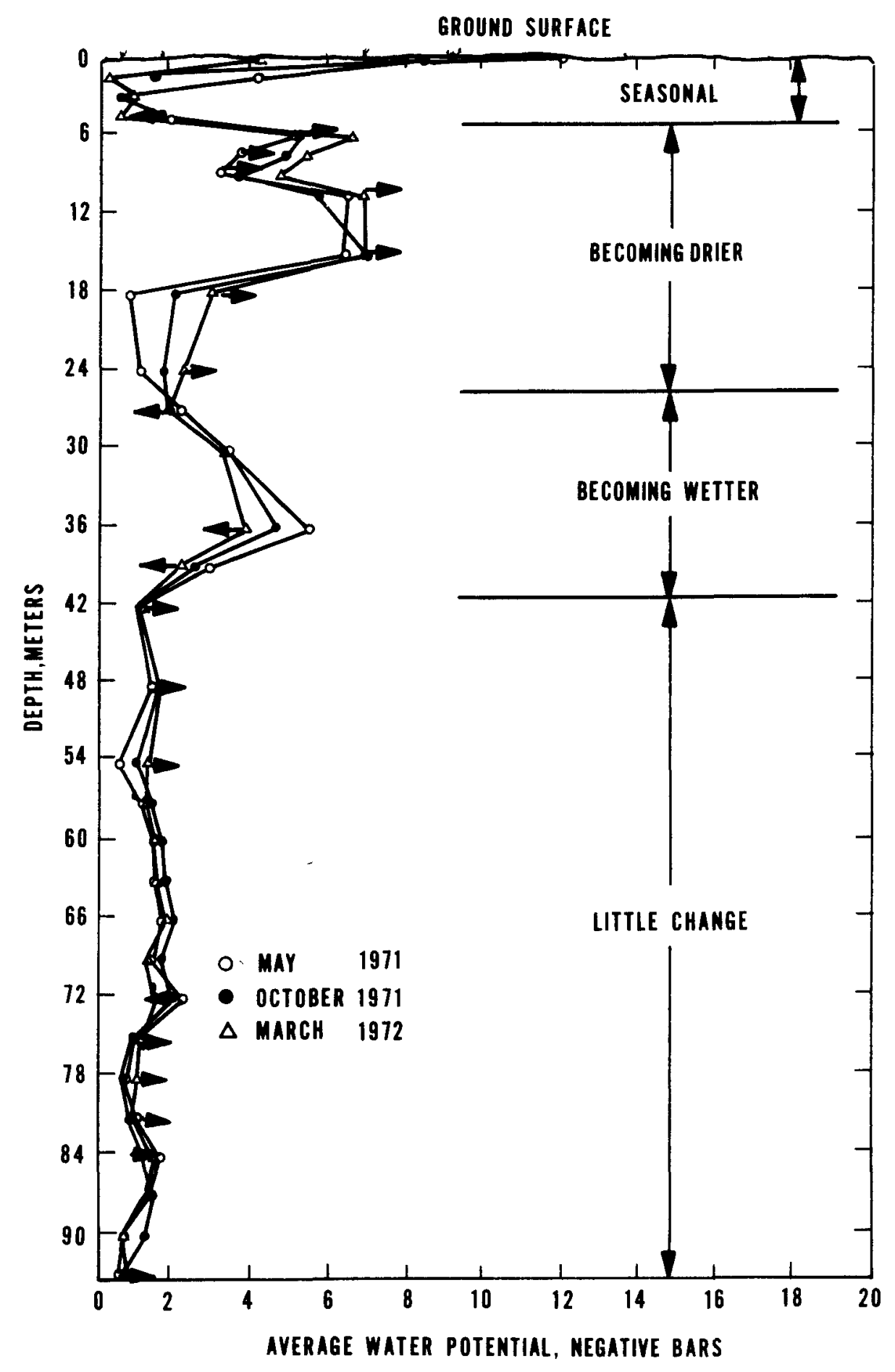

FIGURE 14

AVERAGE IN-SITU WATER POTENTIAL PROFILE FOR WELL 32-49D 


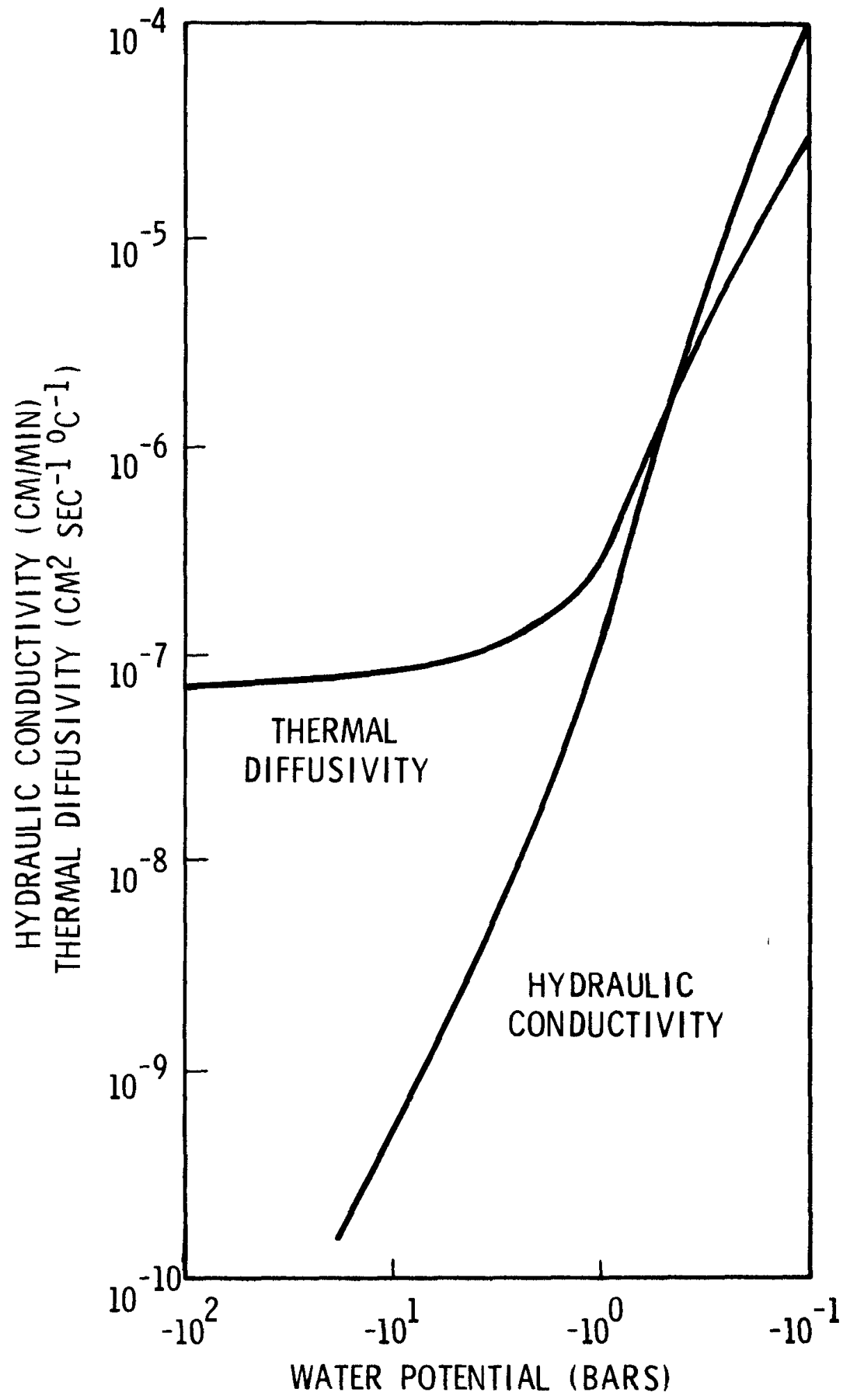

FIGURE 15

HYDRAULIC CONDUCTIVITY AND THERMAL DIFFUSIVITY

AS A FUNCTION OF WATER POTENTIAL FROM SOIL AT 32-49D SITE 


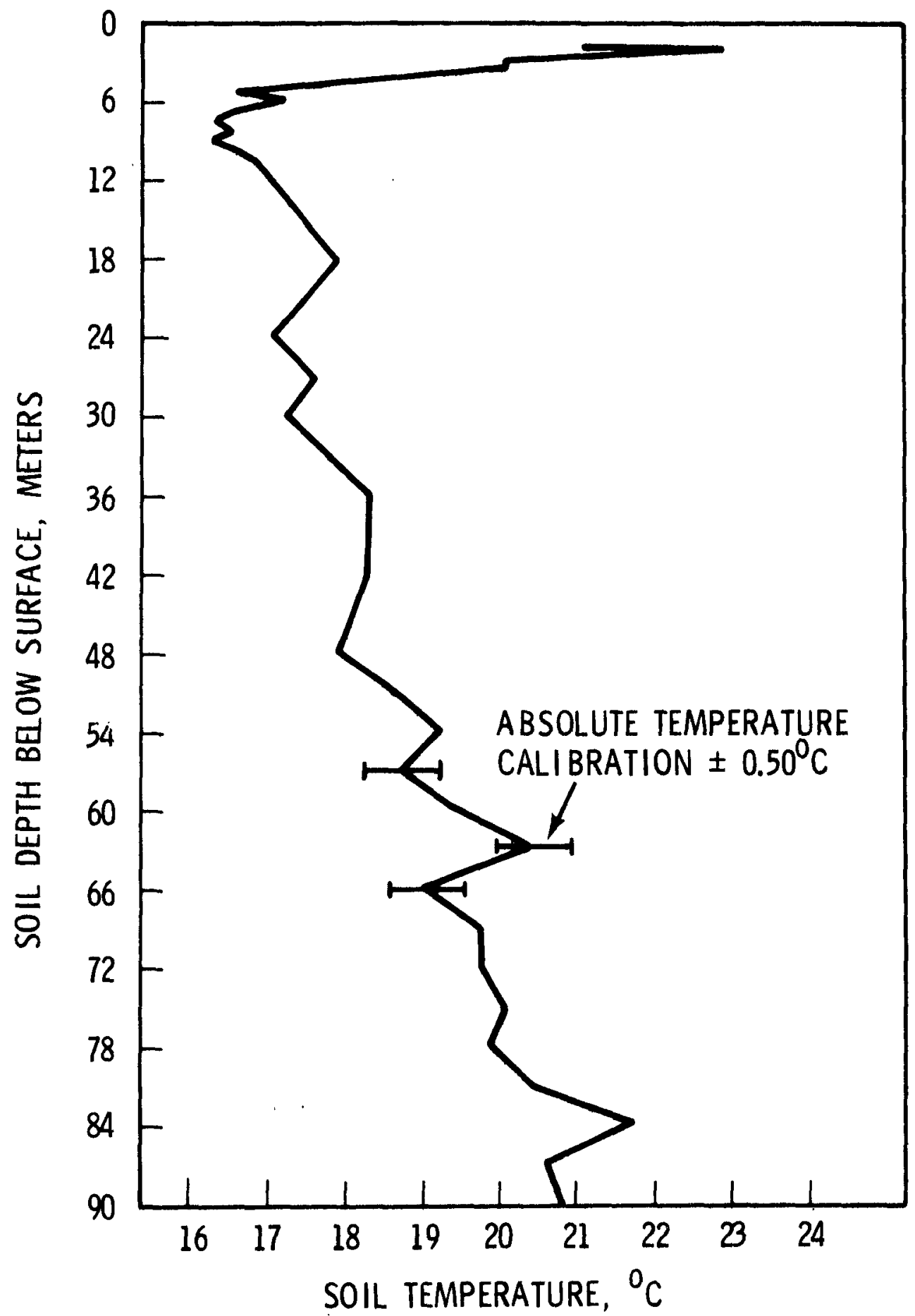

FIGURE 16

SOIL TEMPERATURE PROFILE FOR SITE 32-490

ON OCTOBER 13, 1970 


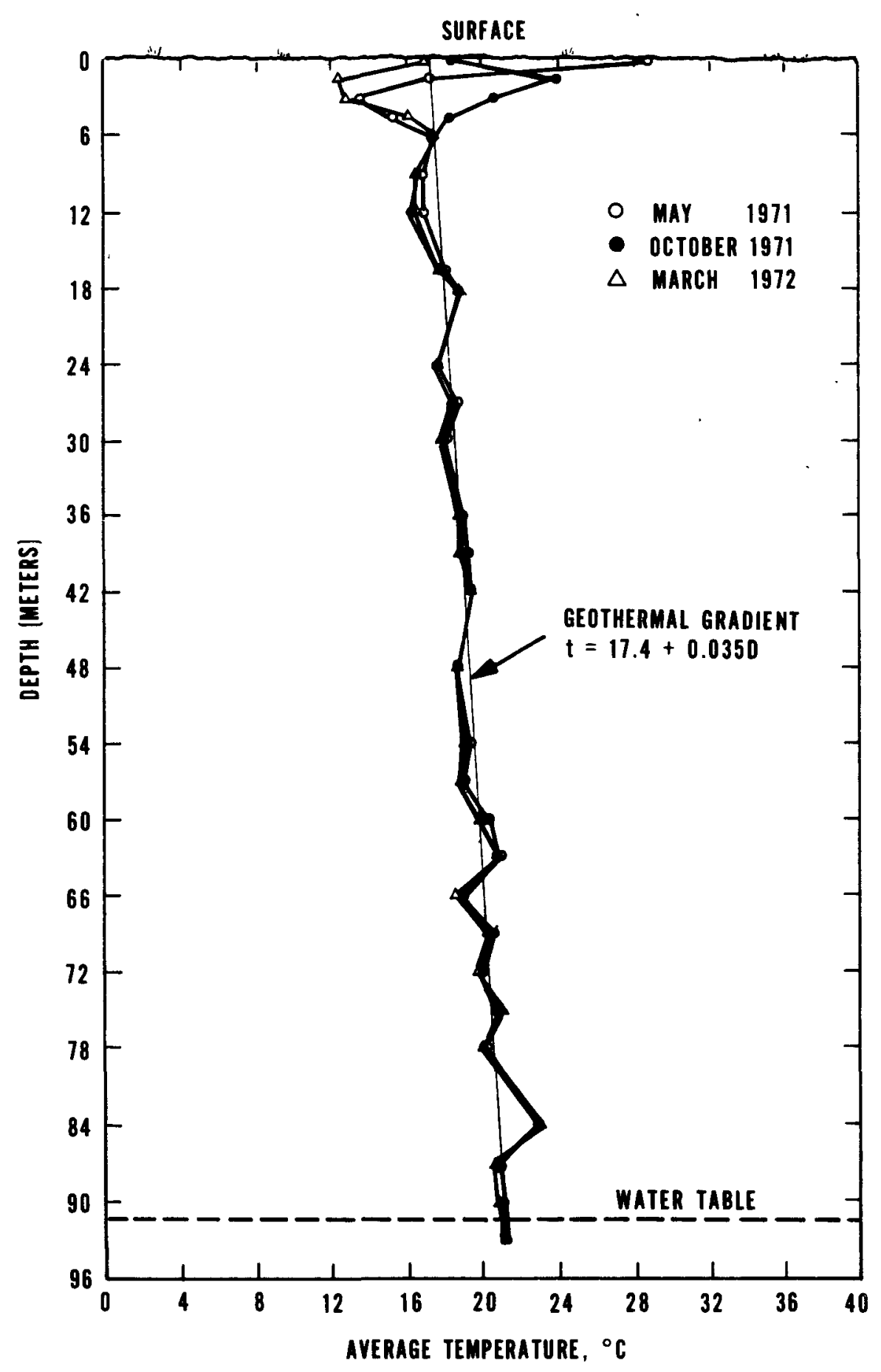

\section{FIGURE 17}

AVERAGE MEASURED MONTHLY SOIL TEMPERATURE FOR THREE SELECTED MONTHS AS A FUNCTION OF DEPTH FOR WELL 32-49D 


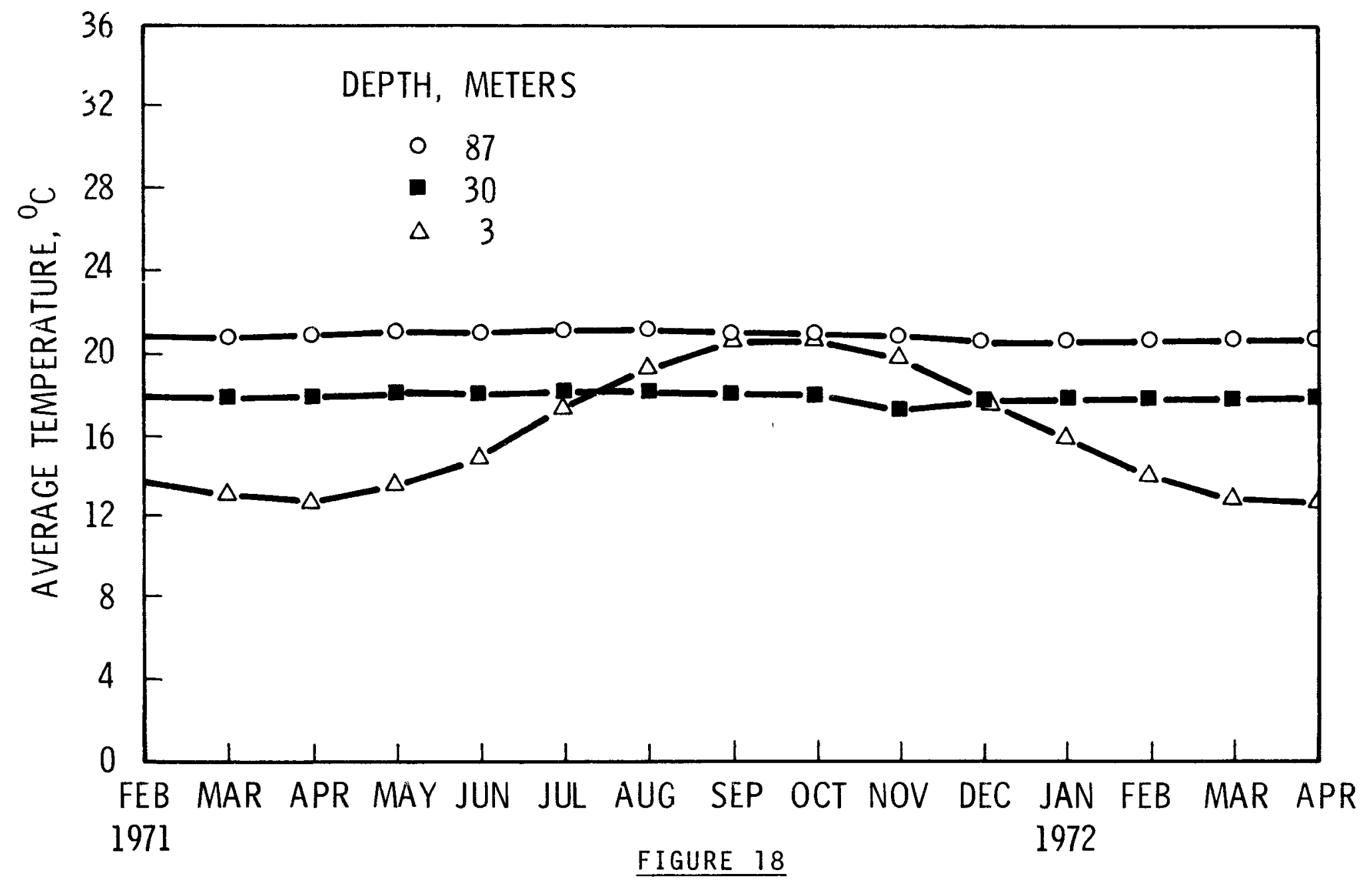

AVERAGE MEASURED MONTHLY SOIL TEMPERATURE $\left({ }^{\circ} \mathrm{C}\right)$ VERSUS TIME FOR SELECTED DEPTHS FOR WELL $32-49 D$ 


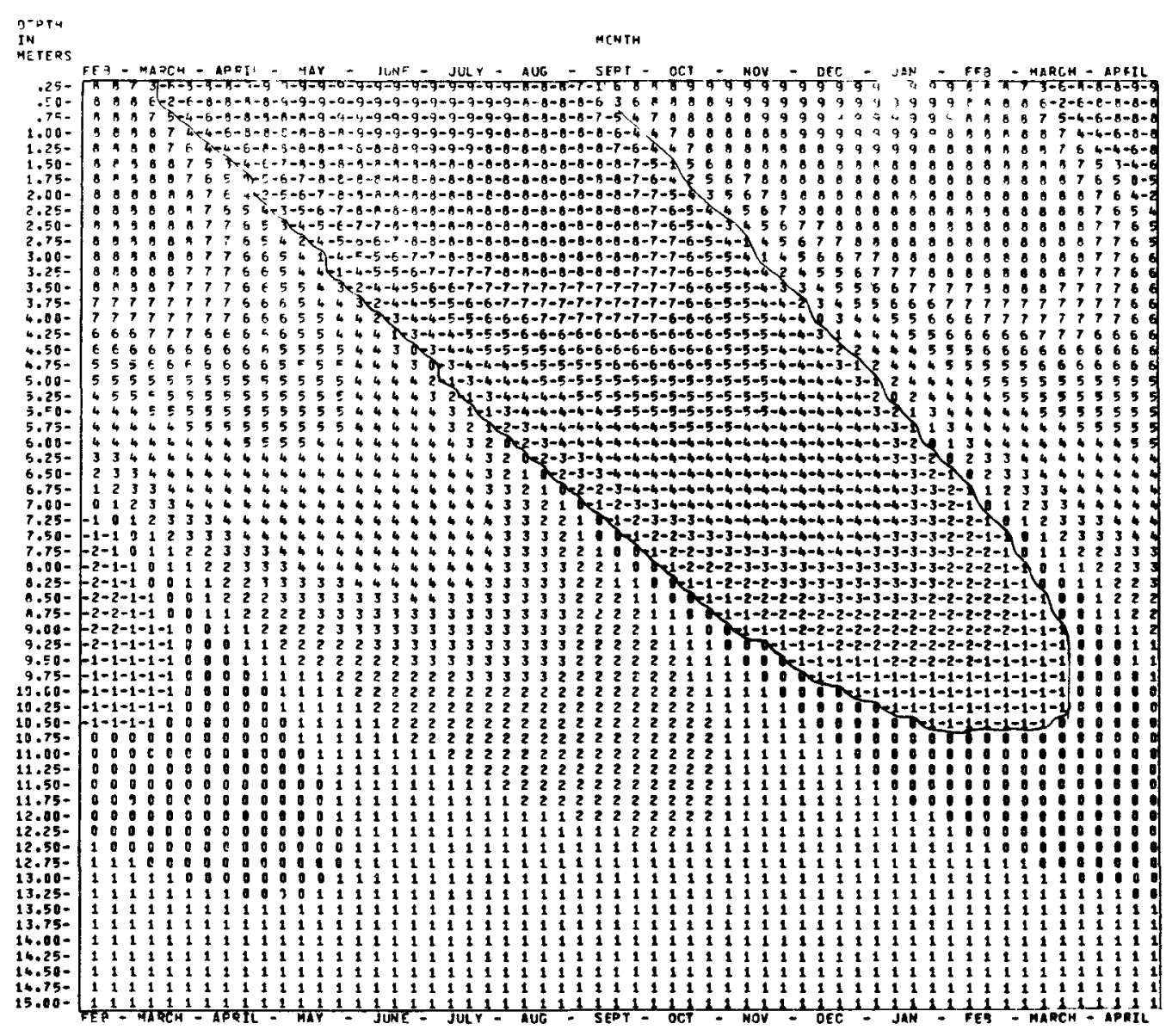

FIGURE 19

MAGNITUDES OF THERMAL DRIVING FORCES

AS A FUNCTION OF DEPTH AND TIME 

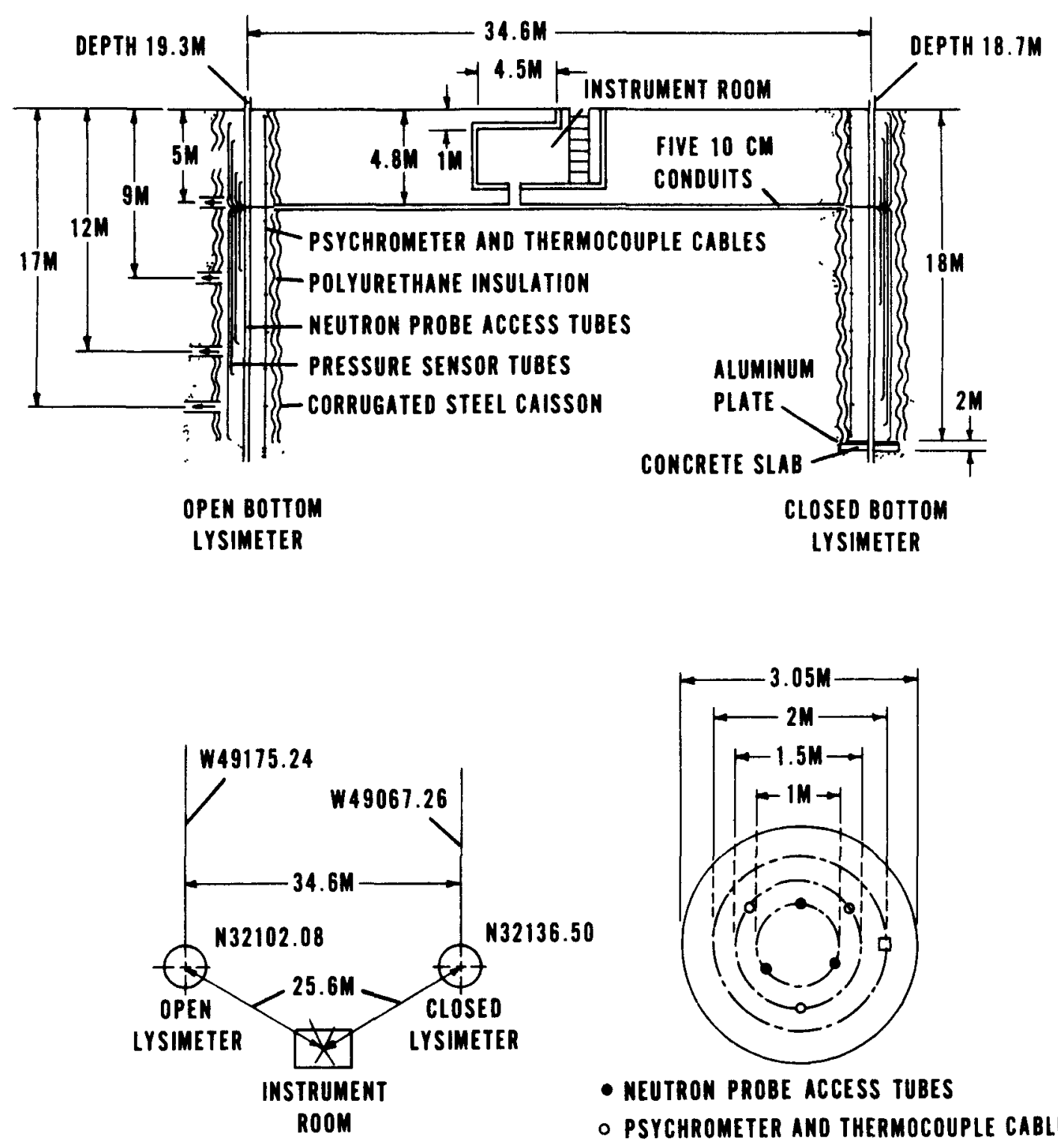

- NEUTRON PROBE ACCESS TUBES

- PSYCHROMETER AND THERMOCOUPLE CABLE

口 PRESSURE SENSOR TUBES

FIGURE 20

SCHEMATICS OF LYSIMETER

INCLUDING SITE ELEVATION AND PLAN OF THE 32-49D HANFORD COORDINATES 


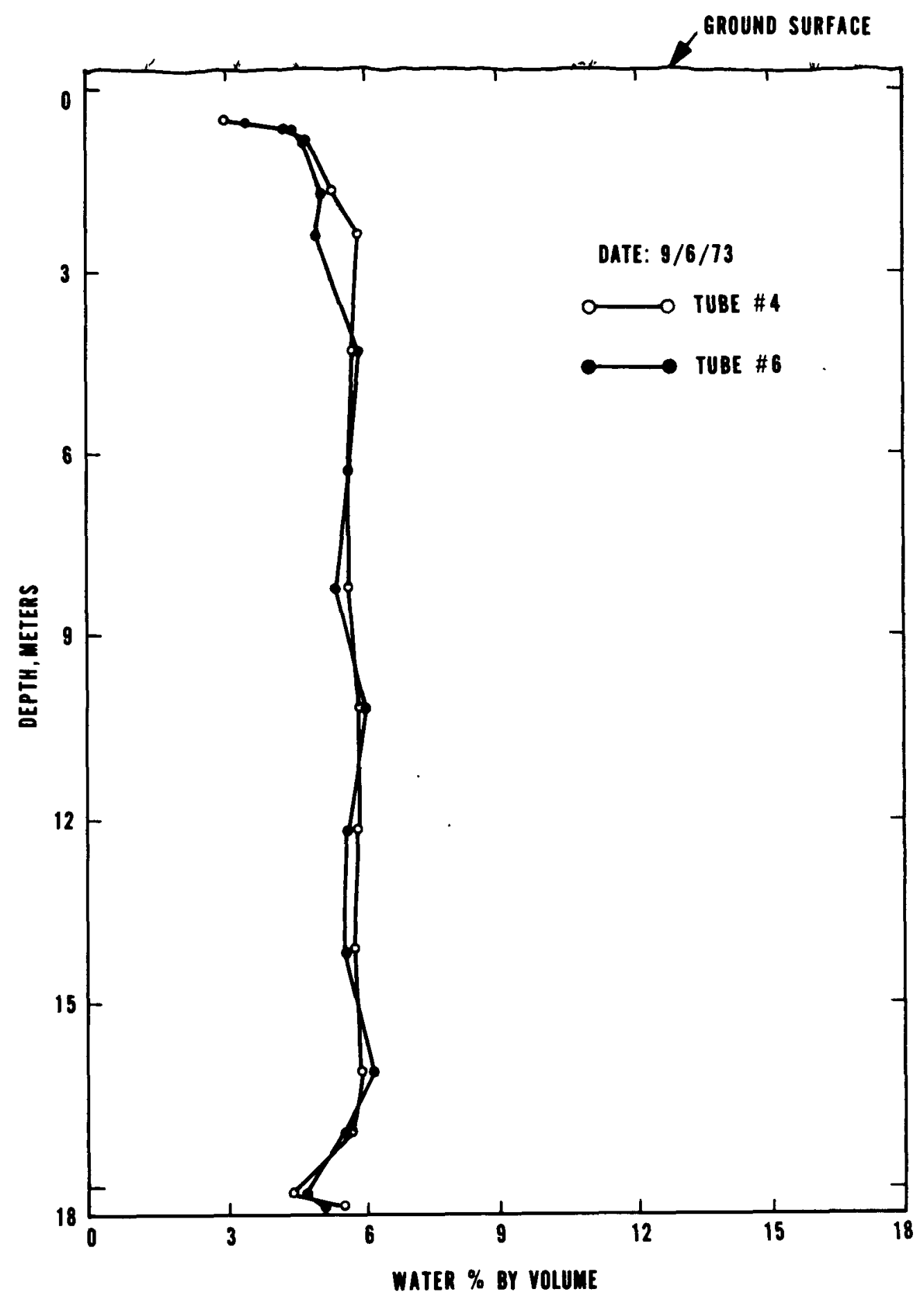

FIGURE 21

CLOSED LYSIMETER MOISTURE PERCENT BY VOLUME AS OF SEPTEMBER 6, 1973 


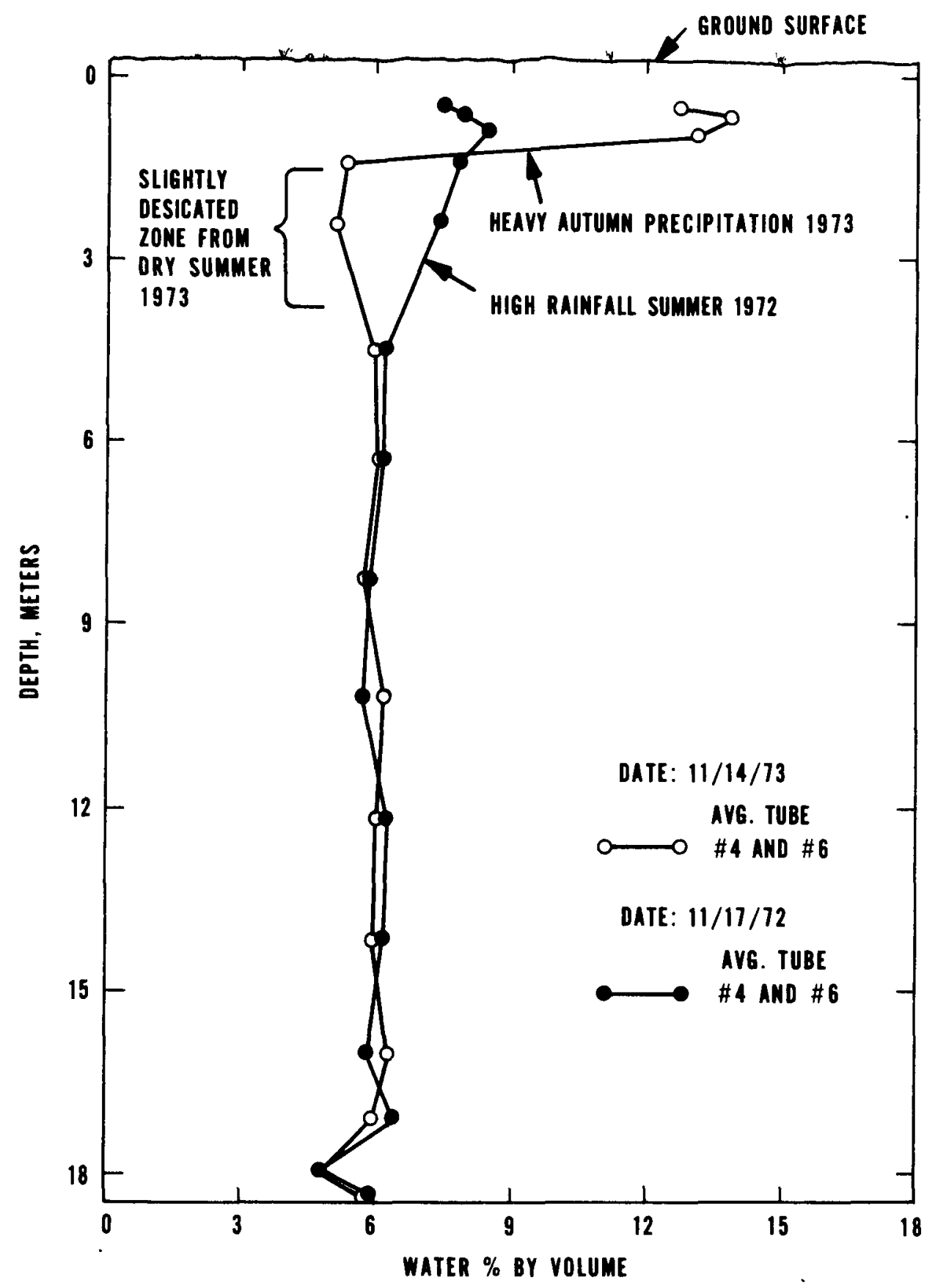

FIGURE 22

\author{
CLOSED LYSIMETER MOISTURE PROFILE \\ PERCENT FOR NOVEMBER 1972 AND NOVEMBER 1973
}




\section{DISTRIBUTION}

Number of Copies

1

1

1

26

3

263

11 $\frac{\text { Atomic Energy Commission Chicago Patent }}{\text { Attorney }}$

A. A. Churm

Atomic Energy Commission; 0ak Ridge Operations Office, Oak Ridge, TN

E. H. Hardison

Atomic Energy Commission Office of Information Services

P. D. Kief

Atomic Energy Commission, Richland Operations Office

0. J. Elgert

R. B. Goranson

P. G. Holstead

B. J. Melton

R. M. Poteat

J. L. Rhoades

D. M. Smith

Atomic Energy Commission, Savannah River Operations office

P. D. Fairchild

A. S. Jennings

I. W. Marine

Atomic Energy Commission Technical Information Center; Oak Ridge, TN

Battelle Pacific Northwest Laboratories

E. L. Alpen

R. E. Bruns

J. P. Croley

J. R. Eliason

R. F. Foster

J. L. McElroy 
Number of Copies

\section{DISTRIBUTION (continued)}

Battelle Pacific Northwest Laboratories (continued)

D. E. Olesen

A. M. Platt

A. E. Reisenauer

J. K. Soldat

C. M. Unruh

Computer Sciences Corporation

R. W. Nelson

Harvard University School of Public Health

D. W. Moeller

1

$\frac{\text { Massachusetts Institute of Technology }}{\text { Cambridge, MA }}$

D.R.F. Harleman

University of Missouri, Columbia, MO

E. L. Roetman

United Nuclear Industries

N. R. Miller

U. S. Committee for the International Hydrological Decade, NAS/NRS, Washington, D.C.

L. H. Heind 1

U. S. Geological Survey Radiohydrology Branch

G. Debuchanane

Atlantic Richfield Hanford Company
G. K. Allen
M. D. Alford
H. Babad
G. E. Backman
C. R. Bergdahl
D. J. Brown 


\section{DISTRIBUTION (continued)}

\section{Atlantic Richfield Hanford Company}

L. E. Brownel 1

L. E. Bruns

G. Burton, Jr.

H. E. Campbeil, Jr.

J. Fauthaber

R. G. Geier

D. R. Gustavson

J. C. Hanson

G. L. Hanson

W. M. Harty

H. H. Hopkins, Jr.

R. E. Isaacson (10)

M. J. Kupfer

D. J. Larkin

C. W. Malody

D. C. Nelson

G. C. Oberg

W. E. Ogren

J. V. Panesko

K. R. Price

S. M. Price

W. H. Price

R. C. Roal

N. C. Rodewald

W. W. Schulz

H. P. Shaw

R. E. Smith

T. E. Sparks

S. A. Spohr

G. T. Stocking

M. J. Szulinski

W. J. Van Slyke

J. H. Warren

R. A. Watrous

G. 0. Wheeler

A. T. White

D. D. Wodrich

ARHCO Document Services

Central File (3) 